\title{
U norden
}

\section{Afsætning af etiske/miljøtilpassede produkter i nordisk detailhandel}

- eksempler på best practice

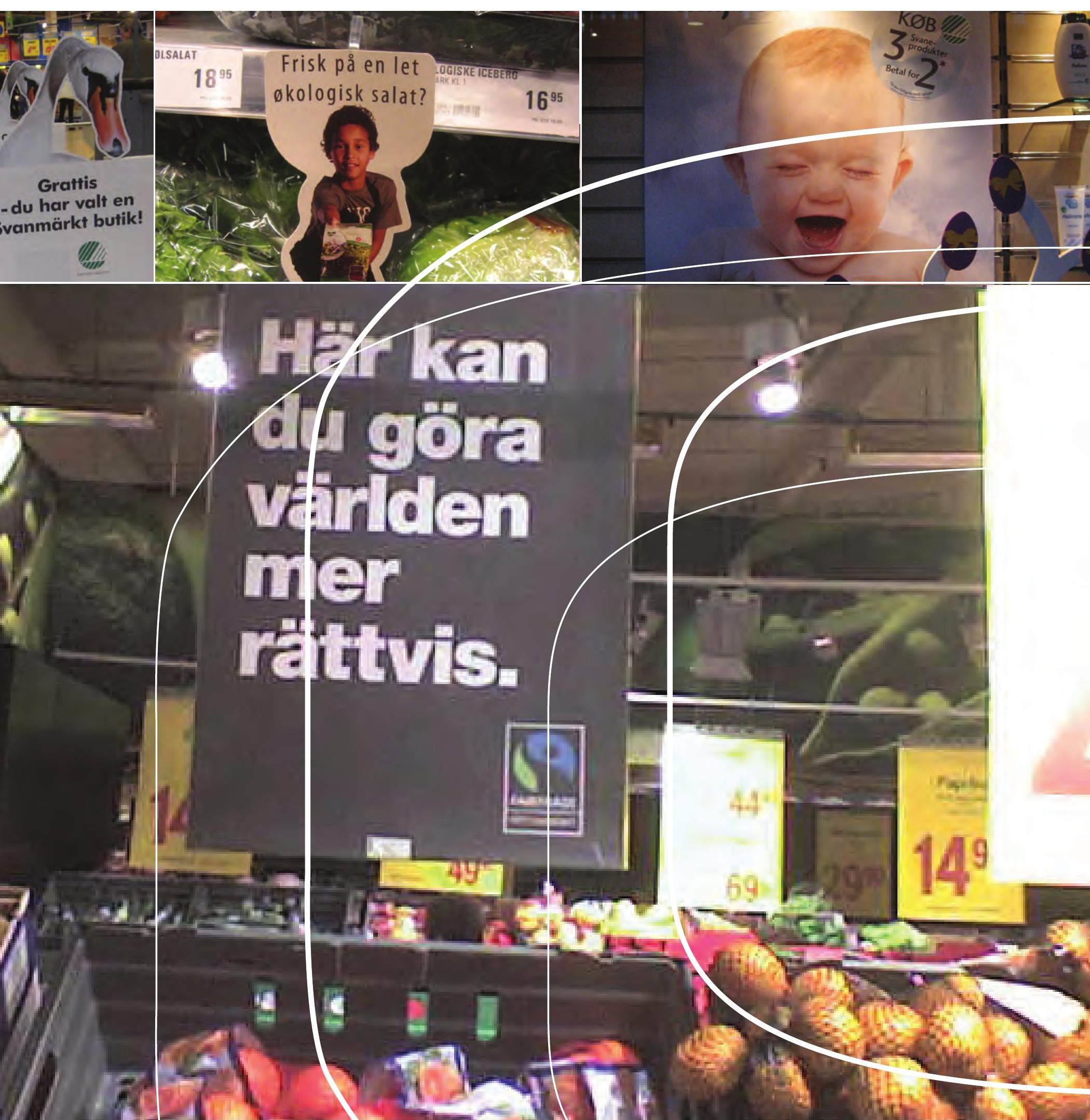



4 norden 



\section{Afsætning af etiske/ miljøtilpassede produkter i nordisk detailhandel \\ - eksempler på best practice}

Kirsten Schmidt, Hanne Møller, Cecilia Solér, Christian Lindskog 
Afsætning af etiske/miljøtilpassede produkter i nordisk detailhandel

- eksempler på best practice

TemaNord 2009:533

(C) Nordisk Ministerråd, København 2009

ISBN 978-92-893-1869-3

Tryk: Kailow Express ApS

Omslag: Jette Koefoed, Publikationsafdelingen NMR

Trykt på miljøvenligt papir som opfylder kravene i den nordiske miljøsvanemærkeordning.

Publikationen kan bestilles på www.norden.org/order. Flere publikationer på

www.norden.org/publikationer

Printed in Denmark

Nordisk Ministerråd

Store Strandstræde 18

1255 København K

Telefon (+45) 33960200

Fax (+45) 33960202

www.norden.org

\section{Nordisk Råd}

Store Strandstræde 18

1255 København K

Telefon (+45) 33960400

Fax (+45) 33111870

\section{Det nordiske samarbejde}

Det nordiske samarbejde er en af verdens mest omfattende regionale samarbejdsformer. Samarbejdet omfatter Danmark, Finland, Island, Norge og Sverige, samt de selvstyrende områder Færøerne, Grønland og Åland.

Det nordiske samarbejde er både politisk, økonomisk og kulturelt forankret, og er en vigtig medspiller i det europæiske og internationale samarbejde. Det nordiske fællesskab arbejder for et stærkt Norden i et stærkt Europa.

Det nordiske samarbejde ønsker at styrke nordiske og regionale interesser og værdier i en global omverden. Fælles værdier landene imellem er med til at styrke Nordens position som en af verdens mest innovative og konkurrencedygtige regioner. 


\section{Indhold}

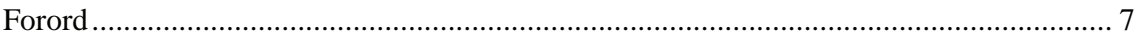

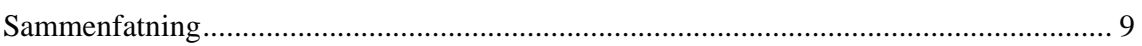

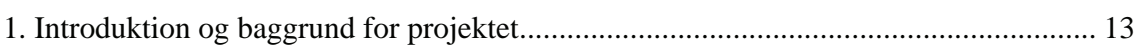

2. Miljøtilpassede og etiske produkter - hvad er det?....................................................... 15

2.1 Mærkerne og deres udbredelse ......................................................................... 16

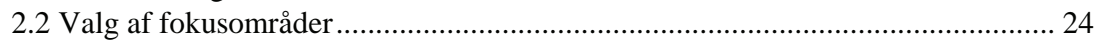

3. Afsætning og omsætning af miljøtilpassede og etiske produkter i Norden.................... 27

3.1 Afsætning i detailhandelen .................................................................................. 27

3.2 Omsætning af miljøtilpassede og/eller etiske varer .......................................... 30

3.3 Strategiske tilgange til synliggørelse af miljøtilpassede eller etiske varer............. 34

3.4 Valg af fokusområder for den empiriske undersøgelse ......................................... 35

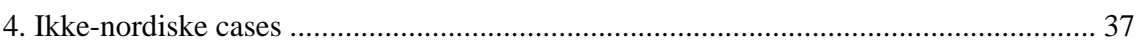

4.1 Acona: The Customer Assumption...................................................................... 37

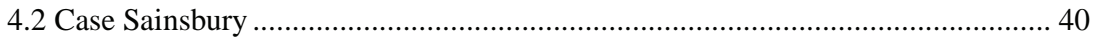

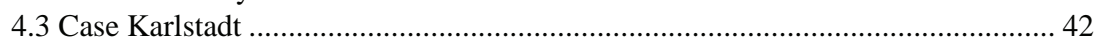

5. Rammer for den empiriske undersøgelse.................................................................... 45



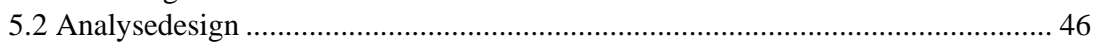

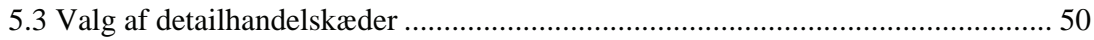

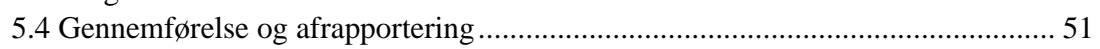

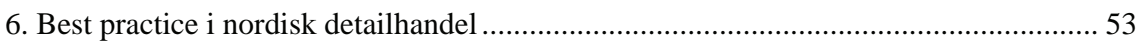

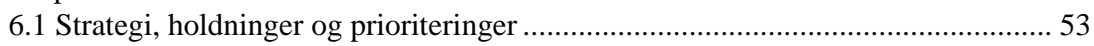

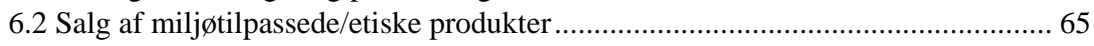



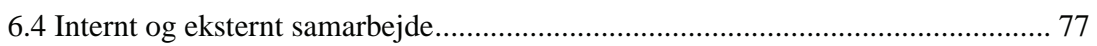

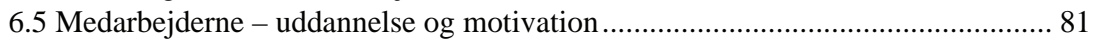

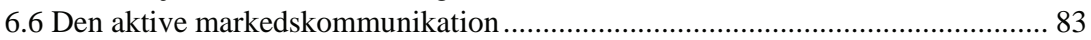



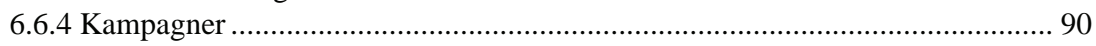

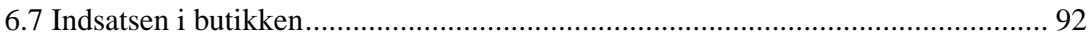

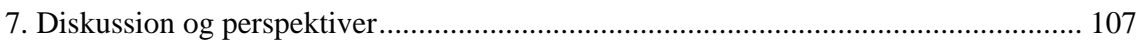

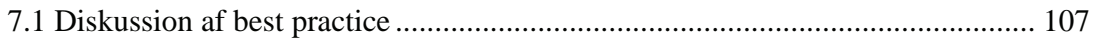

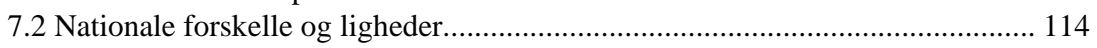

7.3 Forskelle mellem mærkerne ............................................................................. 116

7.4 Konklusion: Hvordan fremme afsætningen af de miljøtilpassede produkter ...... 117

Bilag A: Oversigt over gennemførte interviews og butiksbesøg .................................... 121

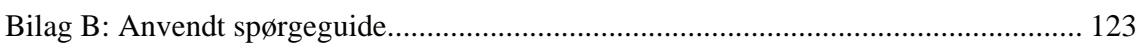

Spørgeguide til interview med central person ........................................................ 123

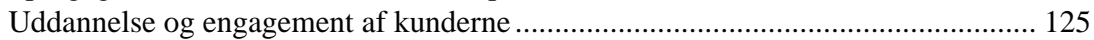

Samarbejde med eksterne parter (NGO'er, medier, organisationer, myndigheder).. 125

Samspil mellem det centrale niveau og kædens butikker ......................................... 126

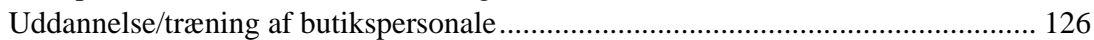

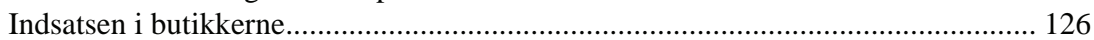

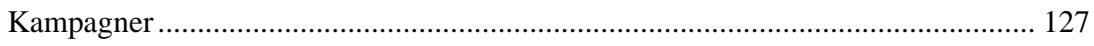

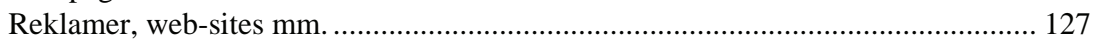

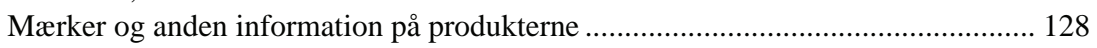






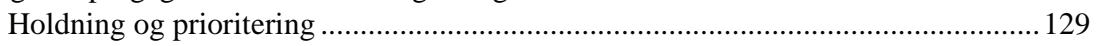

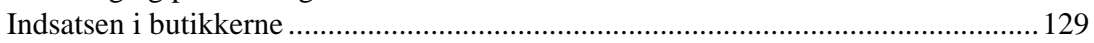

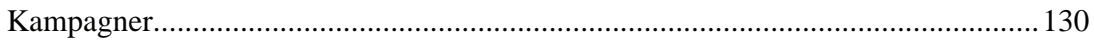

Mærker og anden information på produkterne......................................................130

Uddannelse/træning af butikspersonale ................................................................ 130

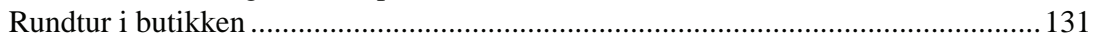

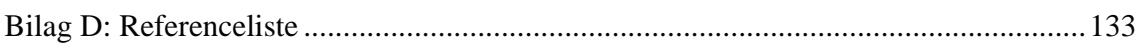

Anvendte kilder til gennemgangen af mærkningsord-ninger og afsætning af miljøtilpassede/etiske produkter ................................................................. 133

Bilag E: Oversigt over projektets referencegruppe …..................................................... 137 


\section{Forord}

Denne rapport er udarbejdet med støtte fra Nordisk Ministerråds arbejdsgruppe for Integrated Product Policy (NMRIPP). 3 personer fra denne gruppe har udgjort projekts styregruppe, det er:

- Claus Egeris Nielsen, Forbrugerstyrelsen, Danmark

- Inger-Grethe England, Statens Forurensningstilsyn, Norge

- Ari Luukinen, Konsumentverket, Finland

Arbejdsgruppen takker for gode input fra styregruppen og fra øvrige medlemmer i NMRIPP-gruppen.

Undervejs i projektet har en tilknyttet referencegruppe læst, kommenteret og givet gode og brugbare tilbagemeldinger. Det har bidraget til dels at kvalitetssikre rapportens indhold og konklusioner, og dels givet nye perspektiver og forståelse for sammenhænge omkring miljø i den nordiske detailhandel. Referencegruppens medlemmer fremgår af Bilag E, og arbejdsgruppen vil rette en stor tak til dem, der har prioriteret at bruge tid på dette projekt.

Endelig skal der også lyde en stor tak til alle de personer i den nordiske detailhandel, som velvilligt har bidraget med information i forbindelse med interviews og efterfølgende, og som har vist os rundt i butikkerne og forklaret, hvordan de arbejder med at fremme salget af miljøtilpassede og etiske produkter.

Projektet har fokuseret på at indsamle eksempler på best practices for afsætning af miljøtilpassede og etiske produkter i detailhandelen i Norden. To forhold er værd at fremhæve. For det første er der tale om eksempler og dermed ikke et samlet billede af indsatsen i den nordiske detailhandel - der er givetvis andre eksempler, som kunne være inddraget. Dette fører frem til det andet forhold, nemlig at de konkrete undersøgelser „i marken“ med besøg og interviews i en række butikker, er gennemført i Norge, Sverige og Danmark. Denne afgrænsning er primært foretaget af ressourcemæssige årsager. De indledende kapitler med baggrundsinformation om markederne i de nordiske lande indeholder derimod også oplysninger vedrørende Finland. 



\section{Sammenfatning}

Som bindeleddet mellem producenter og forbrugere har detailhandelens holdninger, prioriteringer og indsats betydning for markedsføring og salg af miljøtilpassede/etiske produkter. Dette projekt undersøger og synliggør via eksempler på best practices i Danmark, Norge og Sverige, hvordan detailhandelen konkret bidrager til at fremme de miljøtilpassede og etiske produkters position på markedet.

Økologi, fairtrade, sundhed, klimaforandringer og andre miljørelaterede aspekter er kommet højt på dagsordenen de senere år. I detailhandelen ses et stigende antal mærker, som er med til at vejlede forbrugerne og synliggøre hvilke produkter, som ud fra en miljømæssig og/eller etisk vinkel er gode valg. Forbrugernes kendskab til og interesse for de forskellige mærker er stigende, og ganske mange undersøgelser har vist, at forbrugerne ønsker de miljøtilpassede og etiske produkter, og at mange er villige til at betale mere for dem. I praksis viser det sig imidlertid, at når forbrugerne vælger varer på hylderne, er der langt fra de gode intentioner til reel handling - omsætningen af de miljøtilpassede og etiske varer er stigende, men den udgør stadig få procent af den samlede omsætning i detailhandelen.

Imidlertid ER salget af disse varer stigende - der bliver solgt stadig flere forskellige produkter i miljøtilpassede/etiske varianter, lige som der bliver solgt mere inden for de enkelte produktkategorier, og der bliver udviklet varer, som kun findes i fx en økologisk udgave. Samlet set tyder det på, at markedet er under udvikling, og udviklingen bliver båret af en kombination af større efterspørgsel fra forbrugerne, producenternes udviklingsindsats og en større villighed i detailhandelen til at markedsføre de miljøtilpassede og etiske produkter.

Dette projekt ser nærmere på et udvalg af detailhandelskæder i Danmark, Norge og Sverige. Kæderne er valgt ud fra, at de profilerer sig på miljømæssige og etiske aspekter, og at de giver udtryk for, at deres omsætning af disse produkter er stigende. Ved at belyse, hvad kæderne gør på såvel det strategiske som det operationelle plan, giver rapporten eksempler på best practices for afsætning af miljøtilpassede/etiske produkter. Hensigten er dels at give inspiration til detailhandelen bredt set, dvs. ikke kun frontløberne, og dels at opbygge endnu større viden og forståelse hos detailhandelens samarbejdspartnere for, hvordan de kan støtte op om detailhandelens indsats. 


\section{Hovedpointer fra den empiriske undersøgelse}

Best practice i forhold til at sælge miljøtilpassede produkter ses på flere niveauer - fra den strategiske ledelsestilgang til omsætning af strategierne ude i butikkerne.

Ser man nærmere på kædernes strategiske tilgang, er det relevant at skelne mellem „Leaders“ og „Followers“. Leaders er dem, der løber markedet i gang, mens Followers kommer med senere og er så med til at skabe volumen og stimulere konkurrencen. Leaders opbygger miljøbrands, dvs. at de søger at tiltrække de miljø/etisk bevidste forbrugere. De bagved liggende ledelsesbeslutninger er baseret på holdninger, men samtidig handler det om forretning - ikke om filantropi. Opbygningen af miljøbrandet hos leaders sker blandt andet ved at skabe et værdifællesskab med kunderne, hvor de miljøbevidste forbrugere har tillid til, at butikkerne sørger for et ordentligt sortiment af miljøtilpassede/etiske varer, og at disse - ofte dyrere - varer også reelt er bedre. Troværdigheden er vigtig, og her er detailhandelen afhængige af, at myndigheder og organisationer bag de forskellige mærkningsordninger populært sagt „har styr på sagerne“.

Eftersom udvikling af et marked for miljøtilpassede/etiske produkter er en proces, er det vigtigt med en vis dynamik. Der skal nye, spændende produkter på hylderne, og kvaliteten skal være høj. Derfor har leader-kæderne også et tæt og normalt langvarigt samarbejde med centrale leverandører.

I den praktiske indsats rettet mod forbrugerne er sortiment, information og synlighed centrale parametre, men kunder er forskellige, og derfor er der forskel på, hvordan leaderkæderne håndterer disse parametre. Med et udtryk lånt fra detailhandelen, kan de miljø/etisk bevidste forbrugere deles op de „de grønne“ og „de blå“. De grønne har en holdning allerede inden de kommer i butikken og går bevidst efter de miljøtilpassede varer og butikker med et godt sortiment, mens de blå i højere grad skal stimuleres i butikkerne til at prøve en miljøtilpasset variant.

Kæderne med en leader-strategi har en interesse $\mathrm{i}$ at fokusere på de grønne forbrugere. Det er dem, der er med til at drive udviklingen på markedet bl.a. ved at efterspørge nye produkter og ved at være villige til at betale en merpris. Men de blå forbrugere er også vigtige for forretningsudviklingen, fordi antallet af dem er langt større, og de bidrager derfor til at skabe og udbygge et markedsmæssigt volumen. For kæder med en follower-strategi synes det umiddelbart at være mest logisk at satse på de blå forbrugere og dermed på den type miljøtilpassede/etiske produkter, hvor prisdifferencen er mindst. Det er dog væsentligt at nuancere billedet af prisstrategien, da undersøgelsen også har fundet et eksempel på en leader-kæde, som har valgt at eliminere prisdifferencen ved at fordele de ekstra omkostninger til udvikling, dyrere råvarer mm. på alle produkter - konventionelle såvel som miljøtilpassede.

Synlighed, herunder placering i butikken er vigtig for salget af de miljøtilpassede/etiske produkter - lige som for alle andre produkter. Erfarin- 
gerne fra denne undersøgelse tyder på, at det blå segment køber flere miljøtilpassede varer, hvis disse er placeret ude blandt de konventionelle, mens de grønne forbrugere køber mere, hvis de miljøtilpassede produkter står samlet.

Et særligt kendetegn for de miljøtilpassede/etiske produkter er desuden vægtningen af information i markedsføringen. Disse produkter sælger ikke alene på funktion og pris, der er behov for en vedvarende informationsindsats om kædens holdninger og prioriteringer samt om produkternes supplerende fordele - bl.a. for at forklare, hvorfor de i mange tilfælde er lidt eller meget dyrere end de konventionelle produkter.

\section{Den fremadrettede indsats}

Som denne undersøgelse også viser, så er der sket en del på markedet for miljøtilpassede/etiske produkter de seneste år - vækstraterne er pæne og stadig flere detailhandelskæder forhandler disse produkter. Markedet er med andre ord ved at modnes, detailhandelen tager det seriøst som en del af deres forretningspotentiale (dvs. ikke blot af idealisme), og inden for nogle produktgrupper har de miljøtilpassede/etiske produkter store markedsandele.

Når det er sagt, så er der stadig lang vej at gå, før de miljøtilpassede/etiske produkter bredt set bliver mainstream. Samlet set udgør de fortsat få procent af markedet, prisen er en reel barriere for mange forbrugere, og kendskabet til især de nyere mærker er ikke så udbredt. Hvis markedsandelene skal yderligere op i detailhandelen, peger denne undersøgelse på bidrag fra 4 typer af aktører: detailhandelen, producenter, organisationer og myndigheder, som hver især og i samarbejde har mulighed for at stimulere markedsudviklingen yderligere.

Detailhandelen er klart den centrale part. Denne undersøgelse giver adskillige eksempler på, hvordan man kan arbejde bevidst og fokuseret på såvel det strategiske niveau som i den praktiske hverdag i butikkerne. Det er imidlertid også klart, at detailhandelen ikke alene kan løfte udfordringen med at opbygge forbrugernes kendskab og tillid til de miljøtilpassede/etiske produkter og motivere dem til at vælge disse i butikkerne. Forbrugernes holdninger dannes i høj grad inden de kommer i butikkerne.

Producenterne af varer til detailhandelen har en opgave i at fortsætte udviklingen af (nye) miljøtilpassede/etiske produkter til en god kvalitet og pris, hvilket bl.a. kan fremmes via stabile og længevarende samarbejdsaftaler med detailhandelen og i deres egne forsyningskæder.

Organisationer, der står bag de forskellige mærkningsordninger, har en central rolle i fortsat at udbrede kendskabet til deres respektive mærker, sikre troværdigheden og udbrede mærkningerne til stadig flere produkter. Samarbejdet mellem disse og andre organisationer og detailhandelen er vigtig for fortsat udvikling, synlighed og troværdighed. Her er tilbagevendende kampagner, gerne på bestemte tidspunkter hvert år, en god platform for en fælles indsats. 
Myndighederne kan bl.a. spille en rolle ved at støtte op om aktiviteter, der fremmer kendskabet til de forskellige mærker, ved at arbejde for at undgå mærkeforvirring og ved politisk såvel som i den praktiske hverdag at prioritere og efterspørge de miljøtilpassede/etiske produkter. Desuden er der prisparameteren. Nogle miljøtilpassede/etiske produkter er lidt eller meget dyrere end de konventionelle, og det er en reel barriere for hovedparten af forbrugerne. Justering af fx afgiftssystemer, så det økonomisk gavner de miljøtilpassede/etiske produkter, kan overvejes. 


\section{Introduktion og baggrund for projektet}

Økologi, fairtrade, sundhed og klimaforandringer er miljømæssige og etiske aspekter, som er kommet højt på dagsordenen de senere år. Virksomheder over hele verden udarbejder politikker, strategier og handlingsplaner for at blive mere bæredygtige, både i forhold til produktionsprocesser og transport og i forhold til produkterne - alt imens forbrugere og NGO'ere skubber på for at det skal gå endnu stærkere.

De grønne og etiske bølger er også blevet synlige i detailhandelen, hvor omsætningen af svane/blomstmærkede, økologiske, fairtrade og lignende produkter vinder frem, og hvor store detailhandelskæder lancerer ambitiøse politikker og målsætninger. Blandt de mest kendte eksempler er verdens største detailhandelskæde Wal-Mart, som i 2006 annoncerede, at man ville arbejde for at forbedre de miljømæssige og etiske aspekter i såvel butikkerne som i forsyningskæderne. Også i England har supermarkedskæder som Marks\&Spencer, Tesco og Sainsbury profileret deres miljømæssige og etiske standpunkter.

I Skandinavien rækker indsatsen mange år tilbage. Lige siden det nordiske miljømærke Svanen blev etableret i 1989, har det været muligt at købe sådanne miljømærkede varer i detailhandelen, og antallet af miljømærkede produkter har over årene været støt stigende. I de seneste år er der endvidere kommet meget stor fokus på økologi, fairtrade, energiforbrug mm., hvilket har ført til flere forskellige mærker og andre former for miljø- og samfundsrelaterede oplysninger på produkterne. Selv om det tager tid, er forbrugernes kendskab til og interesse for de forskellige mærker stigende, og ganske mange undersøgelser har vist, at forbrugerne ønsker de miljøtilpassede og etiske produkter, og at mange er villige til at betale mere for dem. I praksis viser det sig imidlertid, at når forbrugerne vælger varer på hylderne, er der langt fra de gode intentioner til reel handling - omsætningen af de miljøtilpassede og etiske varer er stigende, men den udgør stadig få procent af den samlede omsætning i detailhandelen.

Imidlertid ER salget af disse varer stigende - der bliver solgt stadig flere forskellige produkter i miljøtilpassede/etiske varianter, lige som der bliver solgt mere inden for de enkelte produktkategorier, og der bliver udviklet varer, som kun findes i fx en økologisk udgave. Samlet set tyder det på, at markedet er under udvikling, og udviklingen bliver båret af en kombination af større efterspørgsel fra forbrugerne, producenternes udviklingsindsats og en større villighed i detailhandelen til at markedsføre de miljøtilpassede og etiske produkter. 
Også myndighederne i de nordiske lande ønsker at stimulere udvikling og afsætning af de miljøtilpassede/etiske produkter, og ud fra en miljøvinkel er der kommet fokus på produkternes livscyklus og samarbejdet i produktkæderne. Her er det klart, at såvel producenter som forhandlere har en rolle at spille i forhold til at udvikle og fremme markedet for de miljøtilpassede/etiske produkter. Mens produktudvikling har været på dagsordenen i mange år, har der ikke hidtil været så meget fokus på detailhandelens rolle. På denne baggrund har Nordisk Ministerråds arbejdsgruppe for Integrated Product Policy (NMRIPP) valgt at sætte gang i nærværende projekt, som har følgende formål:

\footnotetext{
,at kortlægge eksempler på best practice for afsætning af bæredygtige ${ }^{1}$ produkter i den nordiske detailhandel og dermed få en bedre forståelse for detailhandelens rolle og muligheder for at fremme afsætningen af sådanne produkter“
}

Eksempler og erfaringer fra projektet vil kunne bruges som inspiration i detailhandelen og hos de aktører, som ønsker at støtte detailhandelens indsats på dette område. Resultaterne vil ligeledes kunne indgå i arbejdet med at videreudvikle den nordiske og europæiske IPP-strategi.

\footnotetext{
${ }^{1}$ Med „bæredygtige produkter“ menes i denne sammenhæng produkter, som er mindre miljøbelastende og/eller har en bedre etisk profil end tilsvarende konventionelle alternativer. Det er fx svanemærkede, økologiske eller fairtrade produkter
} 


\title{
2. Miljøtilpassede og etiske produkter - hvad er det?
}

\begin{abstract}
Dette kapitel giver - så vidt det har været muligt at skaffe information - et overblik over afsætningen af og forbrugerinteressen for miljøtilpassede og etiske varer i Norden, specielt Norge, Sverige og Danmark. Formålet er ikke at give et totalt billede af, hvordan markedet for disse produkter ser ud, men en baggrund for at udpege, hvor der er best practice erfaringer som grundlag for de empiriske undersøgelser.
\end{abstract}

Begrebet „Miljøtilpassede og etiske produkter“ bruges i denne rapport som en fælles betegnelse for produkter, der er fremstillet med hensyntagen til miljømæssige og/eller sociale forhold og som er tildelt et mærke af en uvildig tredjepart. „Miljøtilpasset“ er i rapportens sammenhæng således et rummeligt begreb, der ikke kun henviser til forhold vedrørende det eksterne naturmiljø, men også til fx sundhed, dyrevelfærd og arbejdsmiljø ${ }^{2}$. Med etiske produkter menes først og fremmest fairtrade. Konkret er der tale om produkter med følgende mærker:

- Miljømærkede non-food produkter (Svanen, Blomsten, Bra Miljöval/ Falken, TCO-mærket)

- FSC-mærkede trævarer

- MSC-mærkede fisk

- Økologiske fødevarer mærket med det danske Ø-mærke, det svenske KRAV-mærke, det norske Debio-mærke, de finske luomu-mærker Luomu-Solen og Luomu-Nyckelpigan eller EU’s økologimærke

- Økologiske og/eller „natur“ kosmetikmærker

- Fairtradeprodukter med det internationale Fairtrade-mærke i kombination med Max Havelaar (Danmark og Norge), Rättvisemärkt (Sverige) og Rejäl handel/Reilukauppa (Finland)

- Andre mærker: ØkoTex (sundhedsskadelige kemikalier i tekstiler), EU's energimærke

Der findes andre mærker, typisk økologimærker fra andre lande, fx SKAL EKO (Holland), Agriculture Biologique (Frankrig), Soil Association (England) samt miljømærket Der Blaue Engel (Tyskland) og Den Grønne Frø (Rainforest Alliance). Disse mærker er imidlertid ikke særligt udbredte på de nordiske markeder og er derfor ikke med i denne undersøgelse. Derimod har enkelte private labels som Coops Änglamark stor

${ }^{2}$ I Sverige bruges begrebet „miljømärkt“ som den overordnede betegnelse, mens en tilsvarende fælles betegnelse ikke findes i Norge og Danmark. Vi har valgt begrebet „miljøtilpasset“ ud fra, at det kan forstås og give mening i alle de nordiske lande. 
markedsbetydning og er derfor medtaget i nedenstående oversigt, hvor mærkerne er fordelt efter hvilken type ordning, der er tale om.

\begin{tabular}{|c|c|}
\hline Mærkeordninger & Eksempler \\
\hline Offentlige mærker & $\begin{array}{l}\text { Svanen - det nordiske miljømærke, non-food } \\
\text { EU's Blomst - EU's miljømærke, non-food } \\
\text { EU's energimærkningsordning } \\
\varnothing k \text { kologiske fødevarer: EU: økologisk jordbrug, Norge: } \\
\text { Debio, Danmark: Det røde } \varnothing, \text { Finland: Luomu-Solen } \\
\text { og Nyckelpigan }\end{array}$ \\
\hline Privat organisation & $\begin{array}{l}\text { Sverige: økologi-mærket KRAV } \\
\text { Alle lande: Demeter-forbundets mærke for biodyna- } \\
\text { miske produkter - DEMETER }\end{array}$ \\
\hline NGO-initierede mærker & $\begin{array}{l}\text { Fairtrade-mærket: i Danmark og Norge = Max Have- } \\
\text { laar, i Sverige = Rättvisemärkt, i Finland = Rejäl } \\
\text { handel - fødevarer og enkelte non-food } \\
\text { Bra Miljöval (svenske Naturskyddsföreningen) } \\
\text { - non-food }\end{array}$ \\
\hline $\begin{array}{l}\text { Partnerskabsmærker (fx mellem en organi- } \\
\text { sation og en brancheorganisation) }\end{array}$ & $\begin{array}{l}\text { FSC-mærkede trævarer og papirmasse (Forest } \\
\text { Stewardship Council. WWF er ansvarlig for at udar- } \\
\text { bejde kriterier), } \\
\text { MSC-mærkede fisk (Marine Stewardship Council. } \\
\text { Kriterier er baseret på FAO Conduct for Sustainable } \\
\text { Fisheries) }\end{array}$ \\
\hline Erhvervsorganisationers mærker & $\begin{array}{l}\varnothing \text { kotex Standard } 100 \text { - europæiske tekstilprodukter } \\
\text { uden sundhedsskadelige kemikalier. Styres af Oeko- } \\
\text { Tex Association. } \\
\text { TCO-mærkede elektronikprodukter (Tjänstemännens } \\
\text { Central Organsation i Sverige står bag, men mærket } \\
\text { bruges globalt) }\end{array}$ \\
\hline Private labels & $\begin{array}{l}\text { Coop: „Änglamark" } \\
\text { ICA: "I } ~ E \text { Eco" } \\
\text { MATAS: „De stribede“ }\end{array}$ \\
\hline
\end{tabular}

Med inspiration fra SIFO, Projektnotat n.1 2006: Etisk politisk forbrug s. 26

\subsection{Mærkerne og deres udbredelse}

\subsubsection{Svanen}

Svanen er det nordiske miljømærke. Det blev etableret af Nordisk Ministerråd i 1989, og anvendes i alle nordiske lande. En lang række produkter kan mærkes med Svanen. Det gælder dagligvarer som køkkenruller og shampoo, og det gælder langvarige forbrugsgoder som møbler og computere. Serviceydelser kan også svanemærkes, fx butikker, hoteller og bilvaskehaller. Fødevarer og medicin mærkes ikke med Svanen.

Der er i alt tildelt ca. 1400 svanemærkelicenser i de nordiske lande. Fordelt på de enkelte lande er det følgende:

- Sverige: 900 licenser, som anvendes på omkring 3000 individuelle produkter

- Danmark: 400 licenser, som anvendes på over 2600 produkter

- Norge: 320 licenser på 1370 produkter 
- Finland: omkring 200 licenser, som anvendes på ca. 1200 produkter

- Island: ca. 10 licenser

Kilde: TemaNord 2008:529, s. 50-51.

De mest udbredte svanemærkede produktgrupper, som henvender sig til private forbrugere, er rengøringsmidler, vaske- og opvaskemidler, sæbe, shampoo og lignende, papirvarer (især husholdningsprodukter), samt møbler.

Det er også muligt at svanemærke butikker, hvilket især er slået igennem i Sverige. Antal miljømærkede butikker i de nordiske lande (foråret 2008):

- Norge: 25, hovedparten i Coop-gruppen

- Sverige: 263, hovedparten i ICA gruppen samt City Gross butikkerne (Bergendahls gruppen). Desuden er 30 butikker mærket med Bra Miljöval, og her er det primært Konsum (Coop-gruppen)

- Finland: 7, alle fra Tradeka Oy

- Danmark: Ingen

Kilder: de nordiske miljømærkesekretariater, www.ecolabel.no, www. ecolabel.se, www.ecolabel.dk, www.ecolabel.fi.

\subsubsection{EU’s Blomsten}

Blomsten er det europæiske miljømærke, som blev etableret i 1992 af EU-Kommissionen og anvendes i hele Europa. EU-miljømærket administreres af Den Europæiske Unions Miljømærkenævn og modtager støtte fra Europa-Kommissionen, alle medlemsstaterne i Den Europæiske Union og Det Europæiske Økonomiske Samarbejdsområde (EØS). Repræsentanter for erhvervslivet, miljøorganisationer og forbrugerorganisationer deltager i Miljømærkenævnet.

Der findes for øjeblikket kriterier for 23 forskellige produktgrupper, og ved udgangen af 2007 er der udstedt 514 licenser, hvoraf de 92 er gældende i de nordiske lande. Fødevarer og medicin kan ikke mærkes med Blomsten.

Kilder: www.ecolabel.com og TemaNord 2008:529 s. 50.

På det danske marked er Blomsten mest udbredt på tekstiler, rengøringsmidler, vaskemidler og maling, mens det på de andre nordiske markeder stort set kun findes på tekstiler. Selv om Blomsten er stærk på enkelte produktgrupper, er den langt mindre udbredt på det nordiske marked end Svanen.

Kilde: www.ecolabel.com, produktdatabasen. 


\subsubsection{EU’s Energimcerkningsordning}

EU's energimærkningsordning for husholdningsprodukter er en obligatorisk ordning, hvor alle produkter omfattet af ordningen mærkes i modsætning til Svanen og Blomsten, som kun gives til produkter, der lever op til særlige kriterier. Produkternes energiforbrug kan aflæses på en skala fra A til G, hvor A står for det laveste energiforbrug. Der er medio 2004 indført 2 nye skalatrin udelukkende for køle- og fryseapparater: A+ og A++.

Følgende husholdningsprodukter er omfattet af ordningen:

- Køle-/fryseapparater

- opvaskemaskiner

- vaskemaskiner

- tørretumblere

- kombinerede vaske-/tørremaskiner

- el-pærer

- elovne

- klimaanlæg til husholdningsbrug

- lyskilder

Ordningen varetages nationalt, og eftersom energimærket er obligatorisk for de produkter, der er omfattet af ordningen, er udbredelsen og kendskabet til mærket stort.

Kilde: Energistyrelsen i Danmark: www.ens.dk.

\subsection{4 Økologimærker}

Der findes flere økologimærker på det nordiske marked. Mindst udbredt er det europæiske mærke for økologisk jordbrug, mens de nationale mærker er langt mere udbredte og kendte af forbrugerne. Det drejer sig om KRAVmærket i Sverige, Debio-mærket i Norge, Ø-mærket i Danmark samt Luomu-mærkerne Solen og Nyckelpigan i Finland ${ }^{3}$. Alle mærker er certificerede og baseret på faste kriterier, som er fastlagt i EU-lovgivningen. Kriterierne omfatter kun selve landbrugsdriften og ikke miljøeffekter knyttet til fx energiforbrug, emballage, transport og bortskaffelse.

Bortset fra enkelte produkter som juletræer, potteplanter og bomuld, bruges mærkerne kun på fødevarer. Økologisk betyder generelt, at der ikke er anvendt bekæmpelsesmidler, kunstgødning, vækstfremmere, bestråling og GMO.

Kilder: Informationscenteret for Miljø \& Sundhed: brochuren „Ren information om mærker og miljø“ samt TemaNord 2007:527.

\footnotetext{
${ }^{3}$ Luomu-nyckelpigan bruges kun på finsk producerede produkter, mens luomu-solen både kan gives til finske og til importerede produkter
} 
En ny EU-forordning, som har til formål at fremme udvikling og afsætning af økologiske produkter, træder i kraft i 2009. Intentionen er også at sikre ensartethed på tværs af de mange, nationale økologimærker, og fremme varernes frie bevægelighed på markedet. Den nye forordning medfører en udvidelse af typen af produkter, som kan opnå det europæiske mærke. Når forordningen træder i kraft, bliver det obligatorisk for producenter af økologiske produkter i EU at anvende det tilhørende EUmærke, men det vil stadig være tilladt at bruge de nationale mærker sammen med EU-mærket.

Kilde: http://ec.europa.eu/agriculture/organic/home_da.

De (nationale) økologiske produkter er velkendte af forbrugerne og har oplevet et stort boom på markedet i de senere år. De mest omsatte varegrupper er mælkevarer, æg, frugt \& grønt samt kød.

\subsection{5 Økologiske og naturkosmetikmæerker}

Der er ingen officiel definition på, hvad økologisk kosmetik er, men flere organisationer har etableret uvildige certificeringsordninger, som sikrer at produkterne indeholder en minimumsmængde af økologiske eller naturlige ingredienser. Følgende mærker har en vis - om end stadig begrænset udbredelse på markederne i de nordiske lande: BDIH, Soil Association samt Cosmebios to mærker BIO og ECO.

BDIH-mærket (Bundesverband deutscher Industrie- und Handelsunternehmen) er formentlig det mest udbredte med omkring 3000 certificerede produkter. BDIH handler om naturlige ingredienser og formålet er at undgå, at forbrugerne bliver vildledt af ordet „naturlig“. Der skal så vidt muligt være økologiske ingredienser i produkterne, men der er som hovedregel ingen minimumskrav til mængden.

Andre mærker handler om økologi. Det er det britiske Soil Association, som er det nationale engelske økologi-mærke. Siden 2002 kan kosmetikprodukter opnå certificering og i dag er der over 2600 certificerede produkter. Endvidere er det standarder fra det franske Ecocert, som også har gjort det muligt at certificere kosmetikprodukter siden 2002. Ecocert standarden danner grundlag for Cosmebiocertificeringen, som har to varianter: BIO-mærket fokuserer på økologi, mens ECO-mærket fokuserer på miljø.

Kilder: Miljøstyrelsen, Urtegården, Ecocert, Cosmebio, Soil Association, BDIH.

\subsubsection{Fairtrade morker}

Fairtrade mærket hedder også Max Havelaar i Norge og Danmark, Rejäl handel/Reilukauppa i Finland og Rättvisemärkt i Sverige. De nordiske 
organisationer er tilsluttet den internationale Fairtrade Labelling Organisation, FLO, og følger retningslinjerne herfra.

Fairtrade-mærkerne er en garanti for fair handel, dvs. at varerne lever op til nogle minimumskrav for betaling, arbejdsforhold, demokratisk udvikling og miljø. Først og fremmest får småbønder og plantagearbejdere en fair pris for deres varer, og pengene går direkte til dem, uden mellemhandlere. Arbejderne er desuden sikret ordentlige arbejdsforhold, og der bliver taget hensyn til miljøet. Fairtrademærkede varer er ikke nødvendigvis økologiske, men mange af dem er begge dele.

Kilde: Max Havelaar Danmark: www.maxhavelaar.dk.

Globalt salgsvolumen af Fairtrade produkter

\begin{tabular}{lrrr}
\hline Produkt & $\mathbf{2 0 0 4}$ & $\mathbf{2 0 0 5}$ & \% vækst \\
\hline Te * & 1.964 & 2.615 & 33 \\
Kaffe * & 24.222 & 33.991 & 40 \\
Bananer * & 80.641 & 103.877 & 29 \\
Frisk frugt * & 5.157 & 8.289 & 61 \\
Sukker * & 1,961 & 3.613 & 84 \\
Honning * & 1.240 & 1.330 & 7 \\
Juice * & 4.543 & 5.898 & 30 \\
Ris * & 1.383 & 1.704 & 23 \\
Kakao * & 4.201 & 5.657 & 35 \\
Blomster *** & 101.610 & 113.536 & 12 \\
Vin *** & 617.744 & 1.129 .508 & 83 \\
Bomuld * & - & 1.402 & - \\
Tørret frugt * & 238 & 306 & 29 \\
Sportsbolde ** & 55.219 & 64.144 & 16 \\
\hline
\end{tabular}

$=$ kubiktons, ${ }^{\star \star}=$ styk, ${ }^{* \star \star}=$ stilke, ${ }^{\star \star \star \star}=$ liter

Kilde: Fairtrade Labelling Organisations International: www.fairtrade.net

Der er (i 2006) udarbejdet fairtrade kriterier for 16 produktgrupper. Ud over de 14, som fremgår af listen ovenfor er det avocado og krydderier \& urter. Kilde: www.maxhavelaar.no.

Fairtrade-mærket er ved at have opnået en høj kendskabsgrad, og omsætningen er i kraftig vækst, men stadig beskeden. De mest omsatte fairtrade produkter i de nordiske lande er kaffe og bananer, men også te, ckokolade og appelsinjuice er godt med. En del fairtrade produkter er også økologiske, og de har så både et fairtrademærke og et økologimærke.

\subsubsection{Bra Miljöval - den grønne falk}

I Sverige har Naturskyddsföreningen sit eget non-food miljømærke - Bra Miljöval, symboliseret ved en grøn falk. Mærket findes på 372 produkter (www.snf.se) inden for følgende kategorier: 


\begin{tabular}{ll}
\hline Kemikalier & Andet \\
\hline - Vaskemidler & - Papirvarer \\
- Skyllemidler & - Tekstilvarer \\
- Pletfjernere og blegemidler & - Elektricitet \\
- Opvaskemidler & - Transport \\
- Sæbe og schampoo & - Butikker (her er det altovervejende \\
- WC-rens & Konsum-butikker, dvs. en del af Coop) \\
- Rengøringsmidler & \\
- Polermidler til biler & \\
- Betonimprægneringsmidler & \\
\hline
\end{tabular}

I Norden er mærket mest udbredt på det svenske marked.

\subsubsection{FSC-mærket}

FSC står for Forest Stewardship Council og er en international non-profit mærkningsordning.

FSC blev grundlagt i Toronto i september 1993 på initiativ fra miljøorganisationer, skovejere, menneskerettigheds- og miljøorganisationer fra 26 forskellige lande. Målet var at skabe nogle fælles globale principper for bæredygtig skovdrift, herunder et nyt gennemarbejdet og troværdigt system, der kunne garantere bæredygtigt produceret træ og papir til forbrugere verden over.

Kilde: www.fsc.dk.

Over 20.000 produkter fra FSC-certificerede skove findes på det globale marked. I dag er FSC-certificering spredt til 84 lande, og 43 lande har egne nationale initiativer, som både handler om certificering af skove og af produkter produceret af træ. Danmark, Sverige og Finland, men ikke Norge, har nationale initiativer, men oplysninger om markeder og produkter er meget begrænsede.

Antal FSC-licenser i de nordiske lande, omfattende både industri- og forbrugerprodukter samt skove:

- Danmark: 70

- Finland: 30

- Norge: 11

- Sverige: 147

Kilde: FSC International, www.fsc.org.

Den begrænsede udbredelse i Norge skyldes, at der er en udbredt skepsis over for mærkets troværdighed - at organisationen bag ikke kan garantere, at de certificerede skove rent faktisk lever op til alle de kriterier, der er en del af ordningen. 
Forbrugerprodukterne er typisk havemøbler, trævarer (både til udendørs brug som hegn og terrasser og til indendørs brug, fx skamler, bakker $\mathrm{mm}$ ), trægulve og papirvarer.

\subsubsection{MSC-mærket}

MSC (Marine Stewardship Council) er en uafhængig mærkningsordning for miljøvenligt og bæredygtigt fiskeri af vildtfangede fisk - og er på nuværende tidspunkt den eneste mærkningsordning inden for dette område. MSC blev etableret af WWF og Unilever i 1997, og i 1999 blev det til en selvstændig organisation. Kriterier bag mærket bygger på FAO Conduct for Sustainable Fisheries og checkes løbende af eksperter. MSC bygger på 3 principper: undgå overfiskning, bevaring af havets økosystem og effektiv forvaltning, der lever op til relevante lovkrav. MSCcertifikatet udstedes til enkelte fiskerier, og der er produkter herfra, der efterfølgende kan mærkes.

Kilde: WWF: www.hvaforenfisk.dk, samt Gemba Seafood Consulting 2007: „Kodeks for et bæredygtigt og ansvarligt dansk fiskeri - Baggrundsrapport nr. 5: Eco-labelling“.

Der findes over 500 MSC-mærkede produkter på globalt plan. I Norden er MSC-mærkningen mest udbredt i Sverige, hvor 13 butikker/kæder forhandler et vist, men ikke stort sortiment. I Danmark forhandles et lille sortiment fra 9 butikker/kæder, mens Norge og Finland har et meget lille sortiment, som sælges i to butikker/kæder. Alle de mærkede produkter er frostvarer, og mærket findes ikke pt. på ferske fisk.

Kilde: MSC Sverige: www.sv.msc.org.

Udviklingen for udbredelsen af MSC-mærket drives af detailhandelskæderne og større fødevareproducenter. Detailhandelen bruger mærket dels som led i kvalitetssikring og risikostyring i deres leverandørkæder og dels som en del af deres branding. Endvidere er den langsigtede forsyningssikkerhed også af betydning for detailhandelens indkøbere, som har oplevet forsyningen af udvalgte fisk falde på grund af overfiskning.

Kilde: IFM og Gemba Innovation, 2007: Resumé af „Kodeks for et bæredygtigt og ansvarligt dansk fiskeri“ samt interview 5/2-08 med Søren Eliasen, IFM (Institut For Marinteknologi).

\subsubsection{0 Øko-Tex}

Øko-Tex er en frivillig sundhedsmærkningsordning for tekstiler, og ordningen styres af den internationale Oeko-Tex Association. Mærket 'Tiltro 
til textiler' viser, at varen er testet og godkendt ud fra de krav, Øko-Texforeningen har stillet. Kravene drejer sig om indholdet af kemiske stoffer, der kan - eller mistænkes for at kunne - skade kroppen.

Mærkningsordningen blev skabt i 1992 af den internationale ØkoTex-forening, Oeko-Tex Association. I dag samarbejder institutter i 12 lande i hele verden om at nå de mål, som Øko-Tex-foreningen løbende sætter. Foreningens stiftere er det østrigske institut Öti, det tyske institut FI Hohenstein og det schweiziske institut Testex. Øko-tex-foreningen er opbygget på basis af standarder, der oprindelig er udviklet af det østrigske institut.

Kilde: www.okotex.dk.

ØkoTex findes primært på tekstiler som håndklæder, sengelinned, madrasser, dyner og puder, men også på arbejdstøj.

\subsubsection{TCO}

TCO-mærkningen er en global 3. partscertificeret kvalitets- og miljømærkning af specielt elektronisk kontorudstyr, men fx også borde og stole. Kriterierne omfatter bl.a. energiforbrug og udledning af varme og stoffer, stråling, ergonomi, samt anvendelse af tungmetaller og flammehæmmere. Formålet var som udgangspunkt primært at sikre et godt arbejdsmiljø, men senere er der kommet flere miljøkrav til. I dag findes mærket på omkring halvdelen af de skærme, som produceres verden over.

Ordningen blev igangsat af den svenske arbejdstagerorganisation TCO (Tjänstmännens Central Organisation), og varetages siden 1999 af den uafhængige organisation TCO Development.

Kilde: TCO Development, www.tcodevelopment.se)

Selv om TCO-godkendelsen findes på næsten alle computerskærme og flere andre produkter på det nordiske marked, bliver det tilsyneladende ikke brugt aktivt i markedsføringen. Mærket sidder på nogle produkter, men der bliver ikke skiltet med det, og butikspersonalet ved ikke, hvad det står for.

Kilde: Miljøstyrelsen 2002, Miljøprojekt nr. 737: „Synliggørelse af de vigtigste forbrugerrelaterede miljøegenskaber ved elektronikprodukter“.

\subsubsection{Private labels}

Coop (alle de nordiske lande) har sit eget miljø/øko private label: Änglamark. Under dette mærke bliver de enkelte landes miljø- og økologiske private labels varer i Coop nu samlet, hvilket betyder, at Änglamark 
fremover vil findes på mange produkter i de nordiske butikker tilsluttet Coop Nordens fælles indkøbssystem ${ }^{4}$.

MATAS i Danmark har haft deres egne private label produkter, kendt som „de stribede“. Inden for de senere år, har MATAS lanceret flere svanemærkede produktserier inden for „de stribede”.

ICA i Sverige har inden for det seneste år lanceret sit eget privat label mærke på økologiske produkter - „ICA - I $\vee$ Eco“. Indtil videre er produktsortimentet begrænset, men det vokser og findes især inden for basisfødevarer.

I Finland har de to største kæder „K-kedjan“ og „S-kedjan“ valgt at økologimærke et udvalg af deres eksisterende private labels discountprodukter frem for at udvikle en selvstændig, miljømærket private labels serie. I K-kedjan, som har private labels mærket Pirkka, findes der således en række Pirkka-luomu produkter, og tilsvarende har S-kedjan Rainbow-luomu produkter.

\subsection{Valg af fokusområder}

Ovenstående gennemgang viser, at der er en hel del mærker og mærkningsordninger i tilknytning til markedet for miljøtilpassede og etiske produkter. Nogle af dem er mere relevante at se nærmere på end andre, fordi de spiller en større rolle i tilknytning til forbrugernes valg og konkurrencesituationen. Som grundlag for valget af fokusområder er der brugt en række kriterier. Det er:

- mærket skal have en god udbredelse med tilhørende kendskab

- det skal være en frivillig ordning, dvs. at der findes både mærkede og ikke mærkede produkter

- mærkerne skal have en vis markedsmæssig betydning, dvs. at der skal være et salg, som detailhandelen tillægger betydning

- der skal være både fødevarer og non-food

- mærkerne skal findes i de tre lande, som indgår i den empiriske undersøgelse, men der kan godt være nationale varianter

Ud fra disse kriterier, og inden de empiriske undersøgelser blev følgende fravalgt:

- Energimærkningsordningen, fordi den er obligatorisk, så alle de omfat-tede produkter er mærkede

- TCO og Økotex, fordi de ikke er kendte på markedet og ikke har betydning for kundernes valg

\footnotetext{
${ }^{4}$ Coop Norden er fra 2008 splittet op i de oprindelige svenske, norske og danske kooperationer, men fortsætter med at have et indkøbssamarbejde
} 
- Bra miljöval, fordi det primært er et svensk mærke

- Demeter-mærket, fordi det primært findes på produkter i specialbutikker (fx helsekostbutikker)

Tilbage er der mærkerne Svanen og Blomsten, Fairtrade, Økologi samt FSC, MSC og Naturkosmetikmærkerne. Det viste sig hurtigt i den empiriske undersøgelse, at FSC, MSC og naturkosmetikmærkerne er meget lidt udbredte, så der er ikke reelt etableret en form for best practice i detailhandelen i de undersøgte lande, og der er kun fundet meget begrænsede eksempler.

Sammenfattende kan det siges, at den empiriske undersøgelse primært fokuserer på miljømærkerne svanen og blomsten samt på økologi og fairtrade. 



\section{Afsætning og omsætning af miljøtilpassede og etiske produkter i Norden}

Som led i afdækningen af, hvor det ville være sandsynligt at finde egnede eksempler til belysning af best practice for afsætning af miljøtilpassede og etiske produkter i de tre lande, der indgår i den empiriske undersøgelse, har arbejdsgruppen set på hvor i detailhandelen disse produkter er synlige for den almindelige forbruger, som ikke har et godt kendskab til specialforretninger for miljøtilpassede eller etiske produkter. Endvidere var det hensigtsmæssigt at se på, hvilke typer miljøtilpassede eller etiske produkter, der er mest udbredte, samt størrelsen og udviklingen i omsætningen. Dette kapitel giver således et overordnet indtryk af salget af miljøtilpassede eller etiske produkter på det nordiske marked ${ }^{5}$, men ikke et egentligt, fuldstændigt overblik, hvilket er uden for dette projekts rammer.

\subsection{Afsætning i detailhandelen}

Detailhandelen kan overordnet set deles op i dagligvarebutikker og specialbutikker. Dagligvarebutikkerne har stor fokus på fødevarer og andre produkter, som anvendes i husholdningen. Specialbutikkerne findes inden for stort set hele produktspektrum, dog primært non-food, selv om der også er specialbutikker inden for fødevaredelen. Der er ikke foretaget en nærmere kortlægning af specialbutikkerne, men enkelte udvalgte kæder indgår i undersøgelsen, fordi de forhandler miljøtilpassede og/eller etiske produkttyper, som har en god synlighed på markedet (se senere) og dermed har potentiale til også at appellere til den almindelige forbruger, der ikke er specifikt miljø eller etisk bevidst i sine indkøb.

De miljøtilpassede og etiske produkter forhandles både i dagligvarebutikker og i specialbutikker. Generelt er tendensen, at dagligvarehandelen, dvs. supermarkedskæderne har den største markedsandel. For eksempel har de traditionelle supermarkeder i Skandinavien $85 \%$ af den økologiske omsætning, hvor økologiske specialbutikker er mere udbredt i Sydeuropa.

\footnotetext{
${ }^{5}$ Dette kapitel indeholder information fra Danmark, Norge, Sverige og Finland, men ikke fra Island og Færøerne
} 
Kilde: Wright and McCrea (ed.) 2007: „The Handbook of Organic and Fair Trade Food Marketing“, s.11.

Det er således relevant at se nærmere på dagligvarebutikkerne med henblik på at lokalisere egnede kandidater i forhold til at finde eksempler på best practice i Norge, Sverige og Danmark. Kædernes egen profilering er blevet screenet ligesom udbuddet af især økologiske og svane/ blomstmærkede varer, eftersom disse to miljøtilpassede produkttyper er de mest udbredte. Desuden er det undersøgt om kæden eller nogle af kædens butikker er miljøcertificeret.

Dagligvarebutikkerne er for langt størstedelens vedkommende organiseret i koncerner/kæder eller indkøbssamarbejder, og dette gælder alle de undersøgte lande. Nogle koncerner har flere kæder under sig og kan spænde over hele spektret fra lavprisbutikker og nærbutikker til supermarkeder og varehuse med et stort sortiment.

De dominerende dagligvarekæder i de enkelte lande er følgende:

Norge:

4 næsten lige store kæder dækker over $90 \%$ af det norske detailhandelsmarked. Det er NorgesGruppen, Coop, Rema 1000 og ICA Norge. Coop Norge omfatter dagligvarekæderne Coop Marked (supermarkeder), Coop Prix (discount), Coop Mega (stormarkeder), Coop Extra (lavpris- og byggemarkeder) og Coop Obs! Hypermarked. Dertil kommer en række specialbutikker.

NorgesGruppen er en samarbejdsorganisation med en række tilknyttede dagligvarekæder - KIWI (discount), Spar (nærbutikker), Meny, Joker, Ultra, Mix, Asko og Storcash.

REMA 1000 er en discountkæde, som ejes af ReitanGruppen. REMA 1000 findes også i Sverige og Danmark. Endelig er der ICA Norge, som indgår i den svensk-baserede ICA-gruppe.

I Norge er Coop kendt for en etisk profil, hvilket bl.a. ses af at Coop Extra kæden er Norges første svanemærkede dagligvarekæde, og af de pt 30 svanemærkede butikker, er de 28 tilknyttet Coop. De sidste 2 er fra Ultra kæden. Også NorgesGruppen, hvor Meny-Ultra kæderne er tilknyttet, er synlige i markedet, specielt inden for økologi.

\section{Sverige:}

I Sverige kontrolleres omkring $90 \%$ af detailhandelen af de 3 kæder ICA, Coop og Axfood, hvor ICA alene tegner sig for omkring halvdelen. ICAkæden består af selvstændige købmænd, der indgår i et indkøbssamarbejde og ICA-gruppen omfatter ICA Sverige, ICA Norge og Rimi Baltic. Coop omfatter kæderne Coop Forum (varehuse), Coop Bygg (byggemarkeder), Coop Extra (stormarkeder), Coop Konsum (supermarkeder) och Coop Nära (nærbutikker). 
Axfood-gruppen omfatter kæderne Willys (discount), Hemköp (nærbutikker) og PrisXtra (Butikker i Stockholmsområdet med fokus på kvalitet). Desuden samarbejdes med at større antal selvstændige købmænd, som er knyttet til de enkelte kæder.

Desuden findes Bergendahl-gruppen, som driver stormarkederne CityGross og EKO, og har indkøbssamarbejde med en del små købmænd.

I Sverige har både ICA og Coop mange års tradition for at prioritere indsatsen for miljø og økologi. En stor del af de 292 svanemærkede butikker i Sverige hører til ICA-gruppen, mens Coop-gruppen i stedet har valgt at blive tilknyttet Bra Miljöval. Medio august 2008 er 29 ud af 30 butikker, som er tilsluttet Bra Miljöval, således fra Coop.

Den nyeste udvikling i forhold til miljømærkning af butikkerne er, at City Gross kæden nu også går efter svanemærket. Her har 12 af kædens 19 butikker indtil videre (foråret 2008) opnået dette miljømærke.

\section{Finland:}

I Finland tegner de to kæder Kesko og S-Kedjan sig for omkring $80 \%$ af dagligvareomsætningen. Kesko, som er den største af kæderne, har i mange år haft et aktivt miljøarbejde og lancerer også fairtrade produkter inden for deres egne mærkevarer.

\section{Danmark:}

3 store aktører - Dansk Supermarked, Coop og Dakofa - dækker tilsammen 80-90 \% af omsætningen i dagligvarehandelen. Dansk Supermarked, som er den største, har kæderne Netto (discount), Føtex (supermarkeder) og Bilka (varehuse).

Coop, som er medlemsejet, har kæderne DagligBrugsen og LokalBrugsen (nærbutikker), SuperBrugsen (supermarkeder) og Kvickly (varehuse) samt datterselskaberne Fakta (discount) og Irma (supermarkeder med særlig fokus på økologi, specialiteter og kvalitet).

Dagrofa, som er den mindste af de 3 aktører, har kæderne SuperBest (supermarkeder), Pisiffik (supermarkeder mm i Grønland) samt Alta (discount). Alta-butikkerne bliver nu omdannet til Kiwi-butikker i samarbejde med den norske discountkæde Kiwi.

Coop Danmark har i mange år været markedsledende på miljøtilpassede produkter i dagligvarebutikkerne, men der er variationer inden for gruppen i forhold til, hvor højt området bliver prioriteret. Datterselskabet Irma, som satser på højkvalitets kundesegmentet, har verdens største andel af økologisk salg målt på omsætningen, mens datterselskabet Fakta, som er en lavpriskæde har et langt mindre etisk sortiment. Også i Coops egne kæder Kvickly og SuperBrugsen har de miljøtilpassede varer høj prioritet. I de seneste år er andre kæder som Netto og SuperBest også begyndt at profilere sig mere på økologi. I det hele taget har den økologi- 
ske/etiske bølge ramt de fleste dagligvarekæder i større eller mindre omfang. Det skyldes formentlig, at forbrugernes interesse for de miljøtilpassede produkter er stigende, og dermed bliver markedet mere interessant.

\subsection{Omsætning af miljøtilpassede og/eller etiske varer}

Der findes ikke megen officiel statistik for omsætningen af de miljøtilpassede/etiske varer, og blandt de organisationer, som står bag de enkelte mærkningsordninger, er der ikke ensartethed omkring hvilke informationer, der er tilgængelige. Enkelte dagligvarekæder giver oplysninger i deres årsrapporter, men det er langt fra alle. Samlet set er det vanskeligt at få et samlet overblik over omsætningen af disse varer og ikke mindst hvordan omsætningen fordeler sig mellem butikkerne. I forhold til at lokalisere eksempler på best practice for afsætning af miljøtilpassede og/eller etiske produkter, har det vigtigste været at afklare hvilke produkttyper, der er mest salg i, og hvem der forhandler disse produkter.

Helt overordnet set tegner der sig et billede af stor omsætningsstigning på økologiske og fairtrade produkter. De svane/blomstmærkede produkter er også i fremgang - stigningstakterne er dog ikke lige så store, men der kommer stadig flere mærkede produkter på markedet. Dagligvarekæderne giver udtryk for, at det stigende salg i et vist omfang er kommet af sig selv ved at forbrugerne er blevet mere miljø- og etisk bevidste og har haft god økonomi og dermed prioriterer at købe de miljøtilpassede/etiske produkter, som i mange tilfælde er dyrere end de konventionelle produkter.

At det kan betale sig at gøre en ekstra indsats fra kædernes side er danske Irma et eksempel på. Her udgør de økologiske produkter omkring $20 \%$ af omsætningen, hvilket er næsten 4 gange så meget som gennemsnittet for den danske dagligvarehandel. I enkelte kampagneuger har Irmas økologiske omsætning været over $30 \%$, og økologien er blevet et trækplaster for Irma. Det, at flere discountkæder nu også har fået økologiske produkter med i sortimentet er ligeledes et udtryk for, at der er et reelt marked for disse produkter.

Der tegner sig et billede af, at økologien er slået mest igennem i Danmark - for de svanemærkede varer er Sverige til gengæld det største marked i de nordiske lande. Økologiens større udbredelse i Danmark kan hænge sammen med, at Danmark traditionelt har en stor produktion af fødevarer. Omvendt var Danmark ikke med i Svaneordningen i de første år, hvor man i stedet satsede på EU’s Blomstmærkning. I Sverige var der fra Svanens start ganske stor fokus på den hjemlige papirindustri bl.a. ud fra et ønske om at nedbringe forureningen af Østersøen. Desuden har Naturskyddsföreningen en konkurrerende mærkningsordning - Bra Miljöval - og konkurrencen mellem de to mærker kan have bidraget til et større fokus og dermed en større samlet gennemslagskraft. 
Med Danmark som eksempel viser tal fra Danmarks Statistik, at den samlede omsætning af økologiske fødevarer i detailhandelen i 2007 repræsenterede en værdi på godt 3,5 mia. DKK. Det er en væsentlig stigning fra 2,7 mia. DKK i 2006, 2,285 mia. i 2005, 2,040 mia. i 2004 og 2,017 mia. i 2003. Mejeriprodukter og æg er langt den største produktgruppe med omkring 1/3 af omsætningen, men andre store produktgrupper er frugt \& grønt, mel \& brød, kød, kaffe, te \& kakao samt andre drikkevarer.

Kilde: Danmarks Statistik www.statistikbanken.dk.

Miljømæerkning har vundet god udbredelse på produkter, som bliver brugt på „1., 2. og 3. lag hud“, dvs. produkter, der bruges på huden fx shampoo, sæbe, kosmetik (1. hud), tøj og kropsnære tekstiler som håndklæder og sengelinned (2. hud) samt produkter, der bruges i hus og hjem fx rengørings- og vaskemidler samt møbler og møbeltekstiler. (3. hud). Fokus har i høj grad været på at undgå kemikalier. Ikke mindst svane/ blomstmærkede babyprodukter og husholdningspapir har vundet stor udbredelse, og produkterne sælges både via supermarkedskæder og via specialbutikker som babyudstyrsforretninger, tøjbutikker, butikker med møbler og andet udstyr til hjemmet samt butikker, der forhandler kropspleje- og kosmetikprodukter.

Tekstiler er en speciel produktgruppe på den måde, at der findes mange mærker: Blomsten, Svanen, Bra Miljöval, ØkoTex og økologisk mærkning af bomuld. Inden for almindeligt tøj synes mærkerne kun at være udbredt på baby- og børnetøj, men der kommer stadig flere miljømærkede tekstilprodukter på markedet for modetøj, hvor „grønt design“ er blevet trendy.

Oplysninger om størrelsen af omsætningen af de svane/blomstmærkede varer er ikke tilgængelige primært af konkurrencehensyn. Men eftersom miljømærkesekretariaterne får licensindtægter fra salget af de mærkede produkter, kan licensindtægterne tages som en strømpil for omsætninger. Der er dog ikke en 1:1 sammenhæng, så tallene skal tages med forbehold ${ }^{6}$. I 2006 havde de nordiske miljømærkesekretariater følgende licensindtægter fra Svanemærkede produkter ${ }^{7}$ :

- Danmark: 793.000 Euro $=5.947 .500 \mathrm{DKK}^{8}$

- Finland: 724.000 Euro $=5.430 .000$ DKK

- Island: 6.500 Euro $=48.750 \mathrm{DKK}$

- Norge: 1.051.098 Euro = 7.883.235 DKK

\footnotetext{
${ }^{6}$ Licenshaverne betaler 0,4 \% i afgift af omsætningen af et svanemærket produkt i Danmark, Norge og Finland, og 0,3 \% i Sverige, men der er både minimums og maksimumsgrænser for, hvor meget den enkelte licenshaver skal betale.

${ }^{7}$ Omsætningen på licenser fra EU-Blomsten er mange gange mindre og indgår ikke i disse tal

${ }^{8}$ Beregnet ud fra en kurs på 1 Euro $=7,5$ DKK
} 
- Sverige: 2.920.000 Euro $=21.900 .000$ DKK

- Samlet: 5.496.000 Euro $=41.220 .000$ DKK

Kilde: TemaNord 2008:529, s. 36.

Tallene underbygger, at omsætningen af svanemærkede produkter er meget større i Sverige end i de øvrige nordiske lande.

Markedsandelen for de svane/blomstmærkede produkter er meget varierende mellem de enkelte produktgrupper, hvor nogle har markedsandele på langt under $1 \%$, mens andre er markedsledende. I Danmark har svanemærket husholdningspapir fx en markedsandel på godt en tredjedel, babyprodukter har mellem knap $10 \%$ og knap 30 \% markedsandel og vaskemidler næsten 20 \%. I Finland er topscorerne køkkenruller med $92 \%$ og toiletpapir med $74 \%$ af markedet, men også universalrengøringsmidler er godt med - her er markedsandelen på $34 \%$.

Kilde: TemaNord 2008:529 s. 52.

Fairtrade produkterne er i stærk vækst i alle lande, men har stadig en meget lille markedsandel. En opgørelse fra den internationale Fairtrade Labelling Organization (FLO) viser, at 2007 var et fremgangsrigt år for fairtrade på verdensplan med en vækst fra året før på 47 \% og en samlet omsætning på omkring 2,3 mia. Euro.

Udviklingen i de nordiske lande har været endnu bedre. Målt på per capita forbrug indtager Danmark en 3. plads globalt med 7,26 Euro. Finland er nummer 6 med 6,54 Euro, mens Sverige og Norge følger efter på 8. og 9. pladsen med et forbrug per capita på henholdsvis 4,63 Euro og 3,92 Euro. I absolut salgsværdi er det nordiske fairtrade marked på 134,8 mill. Euro. Størst i Sverige med 42,5 Mill. Euro (vækst på 166 \% fra året før), efterfulgt af Danmark med 39,6 mill. Euro (vækst \% på 71. Selv om væksten er høj udgjorde fairtrade omsætningen i Danmark mindre end 1 $\%$ af den økologiske omsætning). I Finland var omsætningen 34,6 mill. Euro (54 \% vækst), og i Norge var tallet 18,1 mill. Euro (110 \% vækst).

De største fairtrade produktgrupper er bananer, kaffe, juice, kakao, sukker og te, men også ris, vin og honning er udbredt. Enkelte non-food produkter er kommet godt med, nemlig bomuld, blomster og sportsbolde. Fairtrade produkterne forhandles i dagligvarehandelen, men specialbutikker er også ganske udbredt, lige som en del caféer, restauranter mm. sælger fairtrade produkter.

Udbuddet af FSC- og MSC-mærkede produkter er stadig meget begrænset, og omsætningen er tilsvarende lille. Her er det også et spørgsmål om kendskab, idet mange forbrugere ikke ved, hvad disse mærker står for. Der er ikke tilgængelige oplysninger om omsætningens størrelse, men typiske FSC-mærkede produkter er møbler, brænde, bygningstræ, gulve, husholdningsartikler og papirvarer. 
MSC-mærkede fiskeprodukter omfatter udelukkende frostvarer, og udbuddet er stadig ret begrænset. I Norden er Sverige det største marked i forhold til udbuddet af produkter, efterfulgt af Danmark, Norge og Finland. Udbuddet synes at være langt større i andre europæiske lande som Tyskland, England og Schweiz.

Det har ikke inden for dette projekts rammer været muligt at finde oplysninger om omsætningen af økologi- og naturkosmetikmærkerne, men det skønnes at såvel antallet af mærkede produkter og dermed omsætningen er stigende. Der er dog formentlig stadig tale om en meget lille markedsandel.

\subsubsection{Detailhandelens oplysninger}

Oplysninger om størrelsen af det konkrete salg i de enkelte kæder bliver af nogle betragtet som forretningshemmeligheder, men enkelte kæder er åbne om salget af miljøtilpassede varer. Nedenfor er vist et par eksempler fra Coop Norden og ICA. Begge eksempler viser, at salget er stigende, både i dybden (mere af de enkelte varer) og i et vist omfang også i bredden (større sortiment).

Omsætning af miljøtilpassede varer i Coop i 2005-2006

\begin{tabular}{|c|c|c|c|c|c|c|}
\hline & \multicolumn{2}{|c|}{ Danmark } & \multicolumn{2}{|c|}{ Norge } & \multicolumn{2}{|c|}{ Sverige } \\
\hline & 2006 & 2005 & $2006^{*}$ & $2005^{\star}$ & 2006 & 2005 \\
\hline $\begin{array}{l}\text { Total salg af økologi- } \\
\text { ske/miljømærkede } \\
\text { fødevarer }\end{array}$ & $63.503 \mathrm{t}$ & $54.400 \mathrm{t}$ & $\begin{array}{r}144,3 \mathrm{M} \\
\mathrm{NOK}\end{array}$ & $\begin{array}{r}112,9 \mathrm{M} \\
\mathrm{NOK}\end{array}$ & $\begin{array}{r}622,7 \mathrm{M} \\
\text { SEK }\end{array}$ & $\begin{array}{r}543,7 \mathrm{M} \\
\text { SEK }\end{array}$ \\
\hline $\begin{array}{l}\text { Antal miljømærkede/ } \\
ø k o l o g i s k e ~ f ø d e v a r e r\end{array}$ & 1486 & 1388 & 401 & 408 & 950 & 1254 \\
\hline $\begin{array}{l}\text { Miljømærkede kemiske } \\
\text { produkters \% andel af } \\
\text { salget af kem. prod. }\end{array}$ & 19 & 21 & 36 & 41 & 54 & 59 \\
\hline $\begin{array}{l}\text { Antal miljømærkede } \\
\text { kemiske produkter }\end{array}$ & 41 & 59 & 72 & 49 & 445 & 383 \\
\hline $\begin{array}{l}\text { Miljømærkede hygiejne- } \\
\text { produkters } \% \text { andel af } \\
\text { salget af hyg. prod. }\end{array}$ & 11 & 9 & 35 & 22 & 14 & 26 \\
\hline $\begin{array}{l}\text { Antal miljømærkede } \\
\text { hygiejne produkter }\end{array}$ & 64 & 27 & 39 & 32 & 278 & 189 \\
\hline $\begin{array}{l}\text { Antal miljømærkede } \\
\text { andre produkter }\end{array}$ & 195 & 167 & 126 & 44 & 1034 & 937 \\
\hline $\begin{array}{l}\text { Antal FSCmærkede } \\
\text { produkter }\end{array}$ & 81 & 39 & 35 & 8 & 71 & 118 \\
\hline
\end{tabular}

*2005 er grossistsalg, 2005 er detailsalg (Kilde: Coop Norden årsberetning 2006 s. 12).

ICA-gruppen oplyser følgende om økologiske produkter i sin årsrapport fra 2007

\begin{tabular}{lrrrrrr}
\hline & \multicolumn{3}{c}{ Antal økologiske produkter } & \multicolumn{3}{c}{ Salgsudvikling i \% } \\
& $\mathbf{2 0 0 7}$ & $\mathbf{2 0 0 6}$ & $\mathbf{2 0 0 5}$ & $\mathbf{2 0 0 7}$ & $\mathbf{2 0 0 6}$ & $\mathbf{2 0 0 5}$ \\
\hline ICA Sverige & 370 & 370 & 400 & 28 & 10 & 12 \\
ICA Norge & 350 & i.o. & 157 & 20 & 30 & i.o. \\
Rimi Baltic & 190 & 52 & 7 & i.o. & i.o. & i.o. \\
\hline
\end{tabular}

i.o. $=$ ikke oplyst 


\subsection{Strategiske tilgange til synliggørelse af miljøtilpassede eller etiske varer}

Via den overordnede gennemgang af butikker/kæder, som i henholdsvis Danmark, Norge og Sverige er synlige på markedet i forhold til at markedsføre og sælge miljøtilpassede/etiske produkter og/eller er kendt for at gøre en særlig indsats for miljø og sociale forhold, er der lokaliseret forskellige, strategiske tilgange til at synliggøre den overordnede indsats og/eller produkterne. Nogle kæder prioriterer at synliggøre deres overordnede indsats, men ikke via produkterne. Andre synliggør indsatsen via produkterne og atter andre kombinerer synliggørelsen. Gennemgangen omfatter både dagligvarekæder og specialkæder.

Nedenstående oversigt giver et overblik over disse forskellige tilgange inkl. eksempler på kæder, der repræsenterer de enkelte tilgange. Det skal understreges, at sådanne strategiske tilgange kan udvikles og ændres over tid, ligesom der kan være overlap mellem de enkelte tilgange, ikke mindst i forhold den konkrete (markeds)indsats, som butikkerne anvender. 


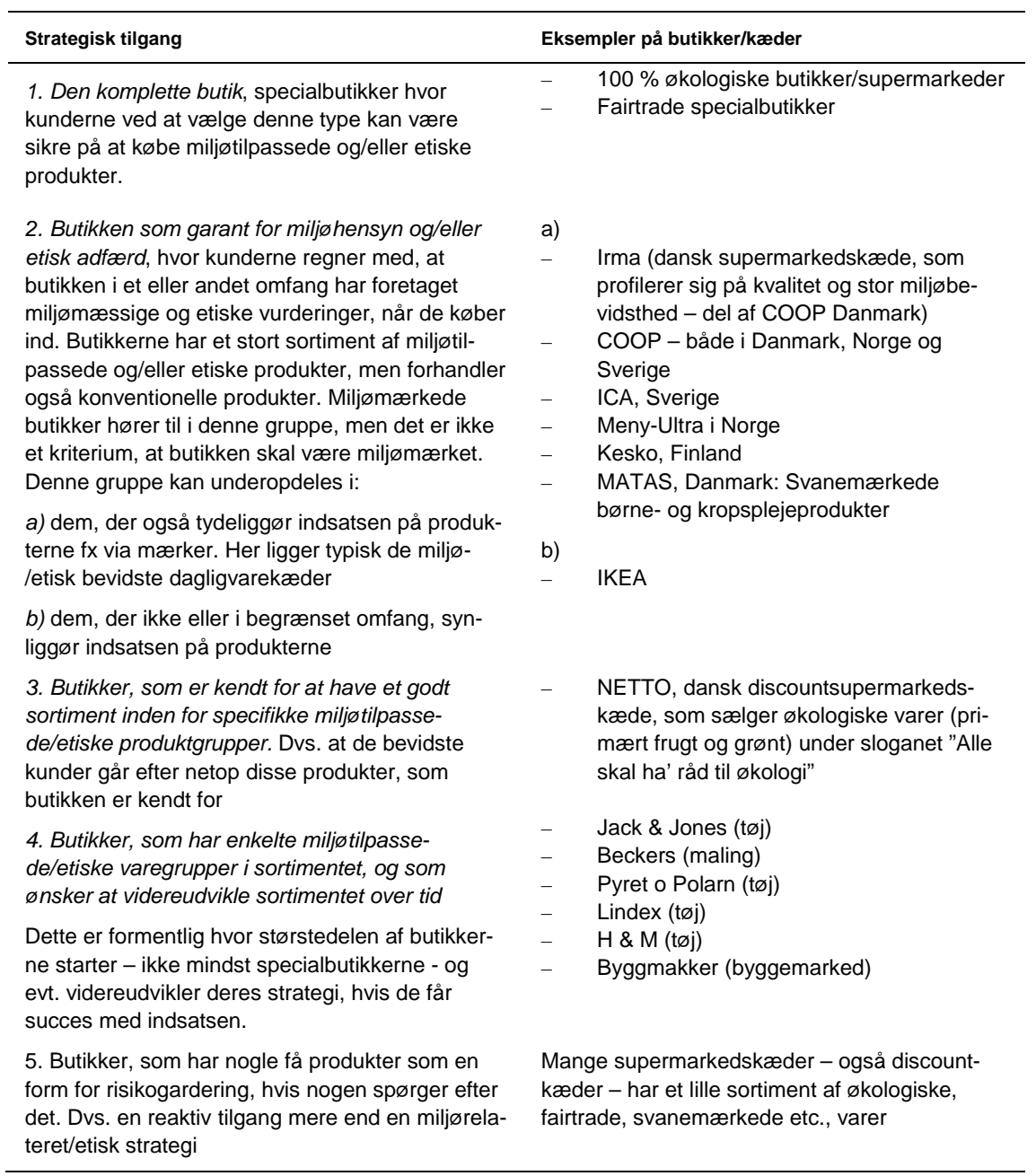

\subsection{Valg af fokusområder for den empiriske undersøgelse}

Den empiriske undersøgelse er gennemført i Norge, Sverige og Danmark, og som beskrevet tidligere i kapitlet forhandles de miljøtilpassede og/eller etiske produkter her i meget stort omfang via dagligvarebutikkerne - det gælder ikke mindst for fødevarerne og for andre produkter, der indgår i en almindelig husholdning. Arbejdsgruppen valgte derfor at fokusere på dagligvarekæderne, specielt dem, der er kendt for en aktiv miljøsatsning, eftersom disse formentlig ville være et godt sted at afdække best practice.

Imidlertid er det også relevant at inkludere specialbutikker, som netop er specialister på et givet produktområde. Her blev der udvalgt en kæde i hvert land inden for produktområder med både synlighed og omsætning på markedet: tekstiler/tøj, baby- og kropspleje samt byggevarer.

I valget er specialbutikker med udelukkende miljøtilpassede eller etiske varer valgt fra lige som den danske Irma-kæde. Årsagen er, at arbejdsgruppen prioriterede butikker/kæder, der henvender sig til den al- 
mindelige, ikke særligt miljø/etisk bevidste forbruger. Grundlaget for den empiriske undersøgelse er nærmere beskrevet i kapitel 5. 


\section{Ikke-nordiske cases}

Dette kapitel samler op på udvalgte erfaringer og interessante cases fra andre lande udenfor Norden. Erfaringerne er blevet indarbejdet i projektets analysedesign, hvor der har været relevant. Men erfaringerne interessante i sig selv og er derfor beskrevet nærmere i dette kapitel

\subsection{Acona: The Customer Assumption}

Acona har gennemført en undersøgelse i UK, bestående af såvel litteraturgennemgang som interviews med 14 virksomheder, der arbejder med CSR - Corporate Social Responsibility - på B2C (Business to Consumers) eller B2B (Business to Business) markederne. Formålet var at afdække barriererne for at bruge CSR aktivt i markedsudvikling samt finde ud af, hvad best practice er ift. at overvinde barrierne. Udgangspunktet for Acona er, at det kan lade sig gøre at skabe forretning baseret på CSR, men det skal gøres bevidst og systematisk som en del af markedsudviklingen. Dvs., at det skal med i markedsanalyser, kundeanalyser, udvikling af markedsstrategier, planlægning af indsatsen osv. Denne del er vigtigere og mere perspektivrig end at tage afsæt i selve salget. Dette følger med, hvis markedsstrategierne er lagt.

I vores nordiske analyse er Business to Consumer virksomheder i fokus, og derfor er der i det følgende kun medtaget de aspekter fra Aconas undersøgelse, der er relateret til B2C.

B2C virksomhederne har været længere tid om at komme i gang med CSR, til gengæld er de bedre til at tænke og udnytte forretningsmulighederne, især fordi de er proaktive og opsøgende - også selv om de godt ved, at de ikke er perfekte. De er ligeledes meget bevidste om, at kunderne både vælger butik OG produkter, når de køber ind.

En vigtig pointe er at fokusere på medarbejderne som ambassadører, og dette er vigtigt i detailhandelen. Kunderne tror mere på, hvad medarbejderne siger, end hvad der står i fine brochurer mm. Mund til mund metoden - „jungletelegrafen“ - er sammen med personlige oplevelser de stærkeste kommunikationsmidler, når kunder tager beslutninger om køb.

Acona lokaliserede 6 almindeligt forekommende barrierer for, at virksomhederne satser på markedsudvikling ud fra CSR-indsatsen:

Customers don't care. Virksomhederne tror ikke, at kunderne er interesserede, og mener derfor, at knappe ressourcer kan bruges bedre andre steder. Som regel er denne holdning ikke baseret på systematiske kvalitative eller kvantitative undersøgelser. 
Customers don't understand. Kunderne forstår ikke kompleksiteten i CSR, og derfor er det for svært at engagere sig nærmere med kunderne på dette område.

A matter of priority. Andre interessenter end kunderne - fx. NGO'er, investorer og myndigheder - menes at være vigtigere i CSR sammenhæng.

The fear factor. Virksomhederne er nervøse for at gå i clinch med kunderne og slippe dårligt fra det. Risikoen for negative reaktioner fra medier og kunder gør virksomhederne tilbageholdende.

Breaking the faith. Virksomhederne opfatter, at det at søge profit og markedsandele ud fra CSR-indsatsen ikke er socialt eller miljømæssigt ansvarligt.

Weak links between Marketing and CSR teams. Der er meget begrænset eller intet samarbejde mellem marketing og CSR afdelingerne. Det betyder, at kundevinklen ikke bliver taget med i CSR arbejdet, og at CSR ikke bliver taget med i udviklingen af markedsstrategierne.

I skemaet nedenfor er de 6 barrierer sammenholdt med Aconas lokalisering af best practice på B2C markederne.

Barrierer for CSR-baseret markedsudvikling - og hvordan de kan overvindes

\begin{tabular}{|c|c|}
\hline $\begin{array}{l}\text { Barrierer } \\
\text { (virksomhedernes opfattelse) }\end{array}$ & $\begin{array}{l}\text { Best practice på B2C markedet } \\
\text { (hvad virksomhederne gør for at overvinde barrierne) }\end{array}$ \\
\hline $\begin{array}{l}\text { Kunderne er ligeglade } \\
-\quad \text { Kunderne siger et og gør } \\
\text { noget andet }\end{array}$ & $\begin{array}{l}\text { - } \quad \text { Gennemfører selvstændige undersøgelser af hvad } \\
\text { kunderne reelt ønsker (surveys, fokus grupper). } \\
\text { Det er ikke nok at inkludere få spørgsmål i alminde- } \\
\text { lige undersøgelser, fordi CSR-området stadig } \\
\text { er nyt. } \\
\text { CSR afdelinger betaler Marketing afdelinger for at } \\
\text { gennemføre analyserne, det giver større } \\
\text { commitment }\end{array}$ \\
\hline $\begin{array}{l}\text { Kunderne forstår det ikke. } \\
\text { - } \quad \text { Kunderne lægger vægt på de } \\
\text { forkerte ting og kan ikke overskue } \\
\text { kompleksiteten, så det er bedre at } \\
\text { gøre det, vi selv ved er vigtigst }\end{array}$ & 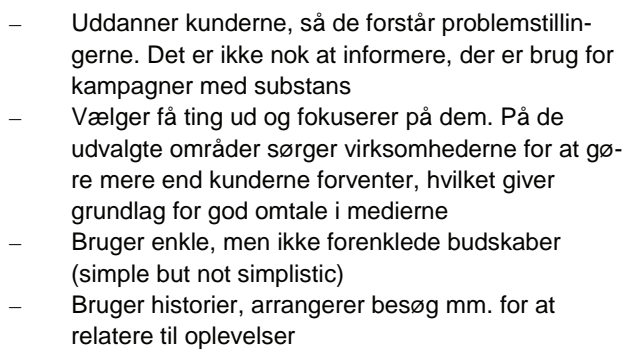 \\
\hline $\begin{array}{l}\text { Et spørgsmål om prioritering } \\
-\quad \text { Kunderne er mindre vigtige end fx. } \\
\text { NGO'er, investorer og myndighe- } \\
\text { der } \\
\text { - } \quad \text { NGO'er opfattes som talerør for } \\
\text { kundeholdninger }\end{array}$ & $\begin{array}{l}\text { - } \quad \text { Integrerer og synliggør kundernes agendaer, selv } \\
\text { om de ikke er de vigtigste set fra en CSR-faglig } \\
\text { vinkel. Arbejder samtidig i baggrunden på de vigti- } \\
\text { ge emner evt. sammen med andre interessenter } \\
\text { (market face vs. backstage issues) } \\
\text { - } \quad \text { Integrerer CSR i forretningsstrategien og måler } \\
\text { indsats og resultater som på andre områder }\end{array}$ \\
\hline
\end{tabular}




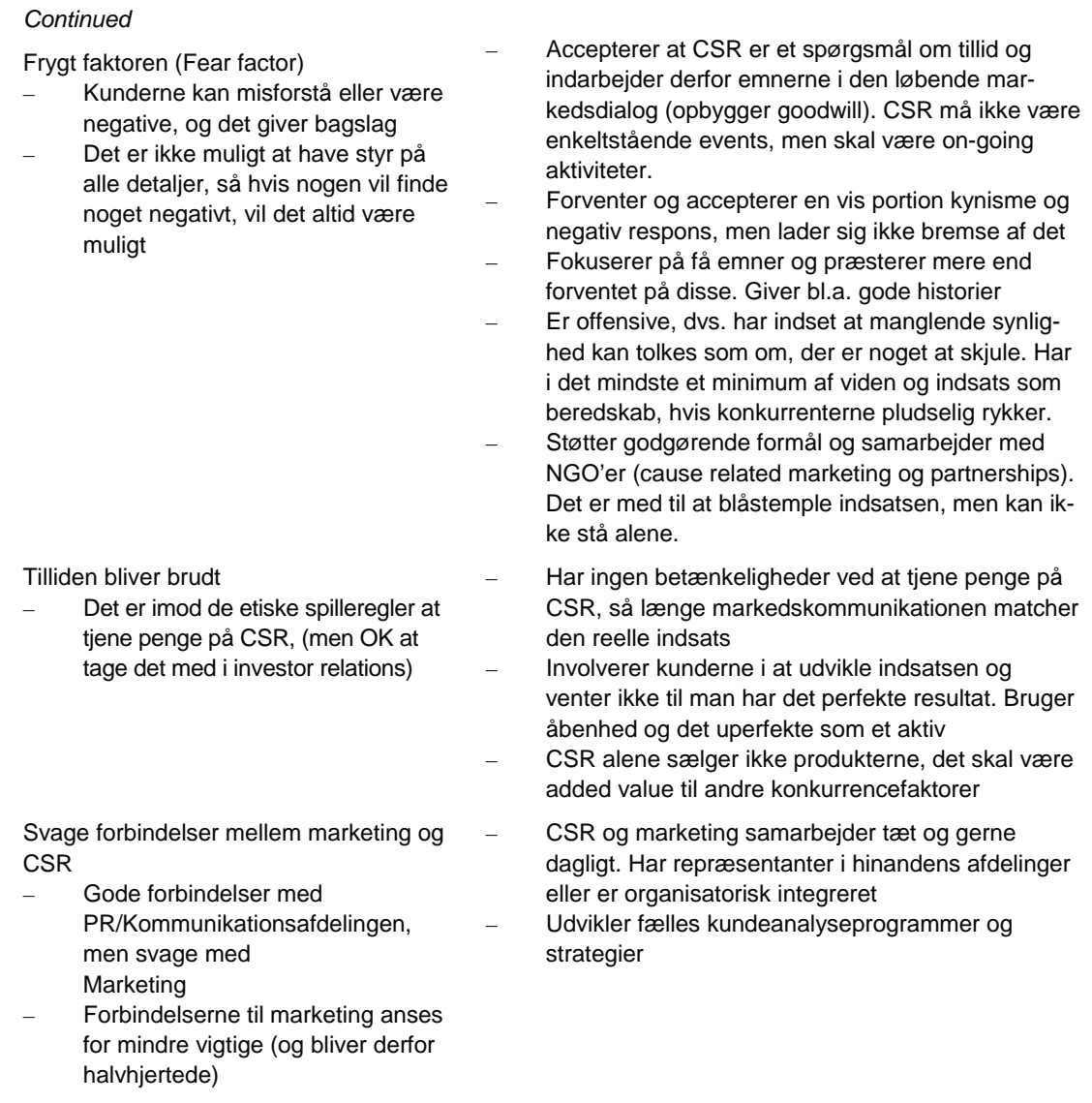

Som konklusion peger Acona på, at best practice virksomhederne:

- Undersøger kundeønsker kvalitativt og kvantitativt (i stedet for at basere sig på „vi tror")

- Bruger CSR-markedsundersøgelser aktivt i forretningsplanlægningen

- Uddanner kunderne og er videnbank for dem

- Erkender risikoen for negativ omtale, men bruger alligevel CSRindsatsen i markedet

- Sørger for at der er hold i CSR-argumenterne

- Opbygger gode relationer mellem CSR og marketing, eventuelt også organisatorisk sammenhæng

- Forstår og anvender medarbejdernes rolle som ambassadører

Aconas undersøgelse siger ikke noget om, hvorvidt best practice virksomhederne har fået større markedsandele, øget profit eller lignende, men alle 14 interviewede virksomheder har været CSR-aktive på markedet i en årrække og har indarbejdet CSR som en del af forretningsgrundlaget. 


\section{Case: Marks \& Spencer}

Den britiske supermarkedskæde Marks \& Spencer indgår i Aconas undersøgelse. I en case er omtalt eksempler på konkrete tiltag hos M\&S.

Indtil 2003 brugte M\&S udvalgte NGO'er som talerør for, hvad kunderne forventede, men fra 2003 har man hvert år gennemført en CSR markedsundersøgelse. Denne viser, at kunderne lægger mest vægt på følgende 7 emner:

- M\&S' ansatte - HR politikker, arbejdsmiljø for de ansatte

- Sundhed - minimere kemikalier, GMO, fedt/salt og tilsætningsstoffer

- Fair over for leverandører - fairtrade samt forhandle britisk producerede fødevarer

- Etisk handel - ordentlige arbejdsvilkår for leverandørernes ansatte

- Bæredygtige/fornyelige råvarer - Bruge uld og bomuld

- Dyrevelfærd - skal tænkes med ved indkøb af bl.a. læder- og uldprodukter

- Filantropi - bidrage til godgørende initiativer

M\&S’ markedsundersøgelser viser, at over halvdelen af kunderne finder CSR vigtigt, og tallet er stigende. Desuden bliver kunderne mere og mere bevidste og vidende, hvilket er med til at flytte grænserne for, hvad M\&S sætter som mål.

CSR er nu blevet en integreret del af markedskommunikationen, og der er et tæt samarbejde mellem CSR-, PR/Kommunikations- og marketingafdelingerne. Blandt andet i forbindelse med lancering af kampagnen „Look Behind the Label“, som havde til formål at informere kunderne om en række CSR emner. Kampagnen bestod af både salgsmateriale i butikkerne, annoncering i medierne, omtale på internettet samt PR-materiale, som bl.a. indeholdt et interview med M\&S' direktør i en BBC morgenudsendelse.

M\&S' kundegrupper er generelt højtlønnede, men dette er ikke en betingelse for at bruge CSR i markedet. Supermarkedskæden Coop bruger også CSR (Fairtrade)-argumenter, og deres kunder er lavindkomstgrupper.

\subsection{Case Sainsbury}

Sainsbury startede sin økologiske satsning i 1986. I midten af 2006 var deres økologiske markedsandel på 30,9\%, mod en samlet markedsandel på 14,7 \%. I 2004 besluttede virksomheden sig for at relancere den økologiske indsats af 3 årsager:

- markedet var i kraftig vækst, hvilket fik flere konkurrenter på banen

- succes med at arbejde med segmentere forbrugerne, og det kunne bruges endnu bedre

- behov for at friske produktsortimentet op 
Inden relanceringen i 2005 blev der gennemført meget omfattende undersøgelser af forbrugernes ønsker og præferencer. De viste, at Sainsbury skulle sætte fokus på sundhed, velvære, babyer og „food as fashion“ hvilket ville dække forskellige segmenters ønsker. Desuden skulle der satses på god smag, på lokale, britiske fødevarer og på at levere mere end forbrugerne forventede, så de ville komme tilbage efter mere. Endelig skulle der være mulighed for at handle økologisk til rimelige priser, men man ville undgå at dumpe priserne, fordi meget lave priser kunne opfattes som et tegn på dårligere kvalitet.

De prispolitikken blev især knyttet til et basissortiment på omkring 100 varer, som skulle være tilgængelige i alle Sainsburys supermarkeder, og disse varer ligger i „begyndervaregrupper“ som frugt, grønt, æg og mælk.

Relanceringen omfattede også nyt brand med et nyt design: Sainsbury SO Organic. Der blev udviklet en designguide, som omfattede al markedsføring, herunder også forskellige måder at synliggøre de økologiske produkter i butikkerne. Formålet var at skabe genkendelighed. I butikkerne valgte man primært at placere de økologiske produkter sammen med traditionelle produkter, fordi det har størst appel til de forbrugere, der ind i mellem, men ikke konsekvent, køber økologisk. De skal opdage de økologiske produkter, der hvor de plejer at komme i butikken.

Desuden arbejder men med såkaldte „destination points“ i butikkerne, dvs. områder med mange økologiske produkter, centreret omkring økologiske storsælgere, men hvor man samtidig introducerer nye produkter. Disse „destination points“ bliver synliggjort over større afstande via skilte, der hænger ned fra loftet.

Ved relanceringen gennemførte Sainsbury en stor kampagne med omfattende annoncering, reklamer mm. Der blev brugt 3 centrale budskaber: høj kvalitet, britiske fødevarer og rimelige priser. I Sainsburys eget magasin blev der skrevet mere udførligt om indsatsen, og der var gode historier om flere produkter. Desuden samarbejdede man med Soil Association, som står bag det britiske økologi-mærke, hvilket var med til at skabe troværdighed. Endvidere havde de største butikker markedspladser med smagsprøver på økologiske kvalitetsprodukter - ikke kun fra eget mærke, men også fra andre, kendte øko-brands.

Et andet aspekt var en omfattende inddragelse af medarbejderne. Først blev der sendt informationspakker til alle kædens butikker med opfordring til at se nærmere på materialet. Derefter var der en konkurrence mellem butikkerne om at sælge flest økologiske varer i kampagneperioden, hvor der også blev serveret økologisk mad i kantinerne. På hovedkontoret blev der holdt „Farmers market“, hvor alle medarbejdere kunne komme og høre bønderne fortælle om deres produkter og driftsforhold.

Resultaterne har været meget gode med tocifrede væksttal siden relanceringen. Undersøgelser viser, at man dels har lokket nye økologiske kunder til, og dels har vundet kunder fra konkurrenterne. 
Kampagner er således et effektivt middel, men resultaterne varer ikke evigt, der skal løbende fokuseres og skabes nyt. Sainsbury har fx valgt at gennemføre særlige sæson-events op til højtider og andre begivenheder. Her handler det om at få forbrugerne til at forkæle sig selv og deres nærmeste med fødevarer af høj kvalitet, som også har et feel-good aspekt.

\subsection{Case Karlstadt}

KarstadtQuelle AG er Europas største kombinerede varehus- og postordrekæde med en omsætning i 2000 på 15,2 mia. Euro og 112.516 ansatte pr 31/12 2000.

Karstadt har arbejdet aktivt med miljøforbedringer siden 1989, og vedtog i 1994 nedenstående miljøpolitik:

- En miljøorienteret virksomhedsledelse bidrager til fremtidssikring af miljøet og virksomheden. Miljøbeskyttelse er derfor en del af vor firmapolitik.

- Ved beslutninger tager vi - inden for rammerne af det økonomisk og teknisk mulige - hensyn til økologiske krav.

- Vi udvider i partnersamarbejde med vore leverandører tilbudene på miljøvenlige produkter og støtter hensigtsmæssige minimeringer af emballage.

- Vi støtter brug og salg af genanvendelige varer og materialer for at undgå affald.

- Vi gennemfører foranstaltninger, som kræver miljøbevidst adfærd af vore medarbejdere.

- Vi støtter henholdsvis institutioner og organisationer ved udarbejdelse og udførelse af økonomiske løsninger i miljøbeskyttelsen.

- Vi informerer kunderne og den interesserede offentlighed om foranstaltninger til beskyttelse af miljøet.

Karstadts miljøindsats fokuserer på 3 hovedområder:

- Begrænsning af eget ressourceforbrug og miljøpåvirkninger i forbindelse med forretningsaktiviteterne. (Dette omtales ikke yderligere i denne case)

- Miljøhensyn ved valg af leverandører og produkter, der forhandles

- Synlighed og påvirkning af kunder, medarbejdere og lokalsamfund

Grundfilosofien er, at det er kunderne, der træffer valgene, men at Karstadt vil gøre det lettere for kunderne at handle miljøbevidst. 


\section{Synlighed og påvirkning af kunder, medarbejdere og lokalsamfund}

For at hjælpe kunderne med at vælge miljøbevidst har Karstadt udviklet et visuelt symbol, som er tydeligt i butikkerne. Symbolet bruges på reoler og lignende ved produkter, der lever op til Karstadts retningslinjer, men ikke på det enkelte produkt. Produkter, der allerede bærer et officielt anerkendt miljømærke, bliver ikke vurderet yderligere, før Karstadt fremhæver dem i butikkerne. Symbolet bruges også i forbindelse med kampagner, reklamer osv. Det er med andre ord Karstadts eget miljøsymbol, som supplerer de officielle miljømærker. Symbolet, som er vist nedenfor, er en vigtig del af Karstadts arbejde med at profilere sig som „det grønne varehus“.

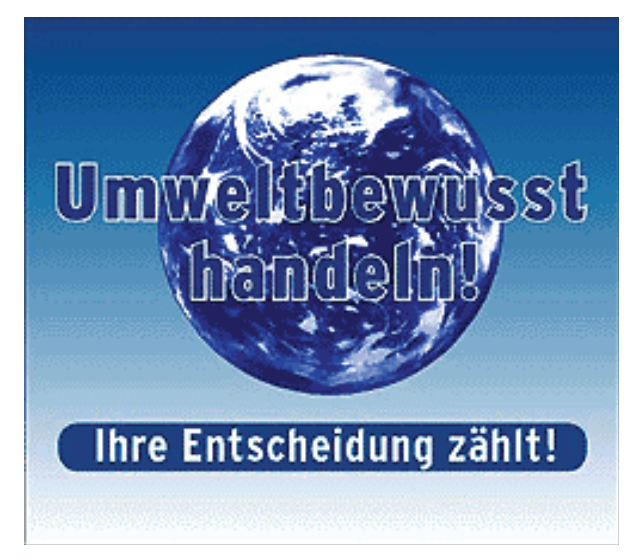

Karstadt har erfaret, at det er nødvendigt at køre omfattende kampagner med mellemrum for at fastholde kundernes interesse for miljørigtige indkøb. I perioder, hvor der ikke er fokus, er der en tendens til stagnerende eller faldende salg - formentlig på grund af at de „grønne“ produkter typisk er lidt dyrere. Til gengæld kan det betale sig at gennemføre kampagner m.m. Resultaterne kan aflæses på salgskurverne, specielt under og umiddelbart efter kampagnen.

Det er vigtigt at bruge mange forskellige midler i en kampagne - både medier, aktiviteter i varehusene og direkte henvendelse til målgrupperne. Karstadts kampagner har generelt stor troværdighed, bl.a. fordi de foregår i samarbejde med såvel myndigheder som miljø- og forbrugerorganisationer.

Desuden tyder det på, at kampagnerne bliver mere virkningsfulde, hvis miljøhensyn kombineres med andre - for forbrugerne - mere konkrete emner. I en vellykket kampagne „1. klasses skolestart“ i 2000 var der f.eks. fokus på både miljørigtige skolesager, sikker trafikvej til skole, gode madpakkevaner - og en konkurrence for børnene om at navngive kampagnens maskot.

Som en meget stor koncern har Karstadt ikke problemer med ligegyldighed hos leverandørerne. Der kan være dialog om retningslinjer og testmetoder, men leverandørerne respekterer Karstadts arbejde. 
Hovedindtryk fra Karstadts holdninger og indsats

- Karstadt har defineret sig selv som brobygger mellem producenter og forbrugere - også på miljøområdet

- Som en stor, international forhandler bruger Karstadt med succes sin position til at fokusere på miljøforholdene ved de varer, man forhandler

- I forhold til forbrugerne kører Karstadt jævnlige miljøkampagner, hvilket er nødvendigt for at fastholde forbrugernes interesse for miljø. Kampagnerne bakkes op af NGO'er, myndigheder m.fl., hvilket giver stor troværdighed. I kampagnerne kombineres miljø med andre forbrugerrelevante emner

- Karstadt har et aktivt samarbejde med lokale medier, hvilket er med til at skabe stor synlighed. Desuden støtter Karstadt andres indsats

- Karstadts overordnede miljøimage er vigtigt. Kunderne skal vide, at når de handler hos Karstadt, handler de med en butik, der har gjort miljøbevidste valg lettere og mere synlige for forbrugerne. Bl.a. derfor har Karstadt valgt at have sit eget miljømærke, som bruges på tværs af produktgrupperne, i reklamer, kataloger, kampagner m.m. 


\section{Rammer for den empiriske undersøgelse}

Dette kapitel præsenterer rammerne for den empiriske undersøgelse, herunder det valgte analysedesign samt hvilke detailhandelskæder, som er indgået i undersøgelsen, og hvordan undersøgelsen er blevet gennemført.

\subsection{Hvad vi gerne vil vide}

Formålet med undersøgelsen har været at afdække eksempler på best practice for afsætning af miljøtilpassede og/eller etiske produkter i den nordiske detailhandel, men best practice kan referere til mange emner fra det overordnede strategiske niveau i kædernes forretningsstrategier til det operationelle niveau i butikkerne. Spændvidden illustreres dels af, at der er gennemført interviews både med kædernes centralt ansvarlige for miljø/CSR og med butiksansvarlige - og dels af de emner, som er blevet indarbejdet i de anvendte spørgeguides.

Der blev udarbejdet en ganske omfattende spørgeguide med emner, det kunne være interessant at undersøge. Men eftersom den samlede mængde af spørgsmål kunne være urealistiske at gennemføre på den tid, der typisk var til rådighed for hvert interview, foretog projektets styregruppe en prioritering af hvilke emner og spørgsmål, som undersøgelsen først og fremmest skulle give svar på. Disse er:

- Hvad opfatter detailhandelen som best practice (herunder forskelle i opfattelser)?

- Hvad virker i forhold til at få forbrugerne til at købe de miljøtilpassede eller etiske produkter - og hvad skaber synlighed og kendskab?

- Hvilke barrierer for salg af miljøtilpassede/etiske produkter møder detailhandelen, og hvordan overvinder de barriererne?

- Hvad virker i forhold til „nye“ miljøbevidste forbrugere og hvad skal der til for at få folk til at købe endnu flere af disse produkter, når de er begyndt?

- Hvilke budskaber har stor gennemslagskraft?

- Er det butikkens/kædens holdninger og indsats, eller er det produkterne, som primært skal profileres for at øge omsætningen?

- Hvordan bliver strategi omsat til konkret handling? Og hvordan er samspillet mellem det centrale niveau og de enkelte butikker? Hvad er de vigtigste drivkræfter for at øge afsætningen af miljøtilpassede eller 
etiske produkter (ud over den velkendte med at forbrugerne skal efterspørge produkterne)?

- Hvilke forskelle er der mellem de forskellige typer miljøtilpassede/ etiske produkter (fx økologiske og svanemærkede), og hvorfor er der disse forskelle?

\subsection{Analysedesign}

Rapportens Bilag B indeholder de komplette spørgeguides, som blev brugt ved interviewene.

Spørgeguiden til det centrale niveau i kæden har følgende emner som omdrejningspunkt:

- Markedsstrategi og konkurrence

- Performance - salg/omsætning

- Videnopbygning om markedet

- Uddannelse og engagement af kunderne

- Samarbejde med eksterne parter

- Samspil mellem centralt niveau og butikkerne

- Uddannelse/træning af butikspersonale

- Indsatsen i butikkerne

- Kampagner

- Reklamer mm.

- Brug af mærker mm. på produkterne

Spørgeguiden til butiksniveauet har nogle af de samme emner, men også enkelte, særskilte emner:

- Butiksbestyrerens holdning til og prioritering af de miljøtilpassede/ etiske varer samt vurdering af, hvad best practice er

- Indsatsen i butikken, herunder hvordan kædens overordnede strategi bliver omsat til handling i butikken

- Kampagner - hvad virker?

- Mærker og anden information på produkterne - betydning for forbrugerne

- Uddannelse/træning af personalet

- Rundtur i butikken inkl. fotografering

Interviewene med det centrale niveau blev gennemført først, derefter butiksbesøgene. Inden interviewene blev kædernes hjemmesider og andet tilgængeligt materiale gennemgået med henblik på at få et godt vidensgrundlag for at gennemføre interviewene.

Ud fra en kombination af spørgeguides og følgegruppens prioritering (se ovenfor) blev der endvidere udarbejdet en standardskabelon for afrap- 
portering af de gennemførte interviews. Eftersom der var tale om en kvalitativ undersøgelse, vil resultaterne af et interview altid blive påvirket af måden, spørgsmålene bliver stillet på, og hvordan interviewet udvikler sig. I denne undersøgelse er interviewene gennemført af 3 forskellige personer i Norge, Sverige og Danmark, hver med deres forudsætninger og kendskab til detailhandelen og det miljørelaterede/etiske marked i landet. Skabelonerne - en for det centrale niveau og en for butiksniveauet - lagde op til, at den person, der havde gennemført interviewet, foretog en foreløbig vurdering samtidig med afrapporteringen med det formål at gøre den efterfølgende analyse på tværs af interviewene mest mulig i overensstemmelse med de faktiske interviews. Skabelonerne er vist i boks 5.2.1 og 5.2.2 nedenfor.

\section{Boks 5.2.1: Skabelon for afrapportering af centrale interviews}

\section{Markedsstrategi og konkurrence}

- Beskriv kædens holdning til dens eget ansvar og mulighed for at fremme salget af miljøtilpassede/etiske varer, herunder hvad kæden anser som de væsentligste drivkræfter for øget afsætningen af disse varer

- Beskriv kædens strategi for markedsføring og salg af miljøtilpassede/etiske produkter, herunder

- $\quad$ hvad kæden ønsker at opnå med strategien

- $\quad$ hovedelementer i strategien, herunder betydningen af at profilere kædens holdninger og værdier og betydningen af at satse på specifikke produkter

- $\quad$ kædens vurdering af markedspotentialer og udviklingen af markedet

- Beskriv hvilke barrierer for (større) afsætning af miljøtilpassede/etiske varer, som kæden oplever, samt hvad de gør for at overvinde disse barrierer. Barriererne kan både være interne i organisationen og eksterne i forhold til markedet

- Beskriv hvilke forskelle der er på, hvordan kæden arbejder med de forskellige typer miljøtilpassede/etiske produkter, fx økologiske og svanemærkede produkter. Er der fx forskelle mellem fødevarer og non-food i forhold til segmentering af kundegrupper, avancekalkulationer, typen af markedsføring...

\section{Resultater: salg af miljøtilpassede produkter}

- Noter data for kædens omsætning af miljøtilpassede/etiske produkter fordelt på de forskellige typer produkter (økologiske, fairtrade, svanemærkede, osv.)

- Beskriv kædens erfaringer med, hvad der virker i forhold til at synliggøre kædens holdninger og de miljøtilpassede/etiske produkter samt hvad der virker i forhold til at øge salget $\rightarrow$ hvad er best practice - gerne prioriteret i forhold til hvad kæden selv anser for vigtigst

- Beskriv hvilke typer slogans, budskaber og argumenter, kæden bruger for at afsætte de miljøtilpassede/etiske produkter. Herunder en vurdering af, om de miljørelaterede/etiske argumenter sælger i sig selv, eller om de skal kobles sammen med andre argumenter. Giv gerne konkrete eksempler på budskaber og argumenter sammen med en vurdering af, hvilke målgrupper, som de er rettet mod (segmentering)

- Beskriv hvordan kædens miljø/etiske politik og strategi bliver omsat til konkret indsats i butikkerne 
Vidensopbygning om „det miljørelaterede/etiske marked“

- Beskriv hvordan kæden skaffer sig viden om kundernes præferencer i forhold til de miljøtilpassede/etiske produkter, herunder typen af (markeds)undersøgelser og hvordan resultaterne af undersøgelserne bliver anvendt, dvs. omsat til strategier, prioriteringer, indsats, argumenter

- Beskriv hvad kæden har lært om kunderne og deres miljømæssige/etiske præferencer ud fra gennemførte undersøgelser

- Beskriv samarbejdet mellem kædens miljø/CSR ansvarlige og de markedsansvarlige

- Hvordan spiller vidensopbygningen sammen med best practice?

\section{Uddannelse og engagement af kunderne}

- Beskriv hvad kæden gør for at opbygge kundernes viden om og forståelse for de miljørelaterede og etiske spørgsmål i tilknytning til produkterne. Herunder om man primært argumenterer ud fra fakta eller ud fra oplevelser ( $\mathrm{fx}$ ved at fortælle historier om produkterne eller arrangere besøg hos producenter). Er der tale om et aktivt samspil med kunderne ud over det klassiske sælger-køber forhold?

- Hvordan spiller uddannelse af kunderne sammen med best practice?

Samarbejde med eksterne parter (NGO'er, medier, organisationer, myndigheder,...)

- Beskriv hvem kæden samarbejder med for at fremme salget af miljøtilpassede/etiske produkter, hvad de samarbejder om, og hvad formål og resultater er

- Hvordan spiller samarbejdet sammen med best practice?

Samspil mellem det centrale niveau og kcedens butikker

- Beskriv ansvarsfordelingen mellem det centrale niveau og butikkerne i relation til at sælge miljøtilpassede/etiske produkter. Hvem gør hvad? (indkøb, varesortiment, kampagner, butiksindretning,...)

- Vurder om det centrale niveau eller butikkerne er den vigtigste drivkræft for at fremme salget af miljøtilpassede/etiske varer. Er der konfliktende interesser?

- Hvordan spiller det sammen med best practice?

\section{Uddannelse/trcening af butikspersonale}

- Beskriv kædens indsats for at informere og uddanne relevante personalegrupper med henblik på at fremme salget af miljøtilpassede/etiske produkter og vurder betydningen og effekten af indsatsen

\section{Indsatsen i butikkerne}

- Beskriv hvad kæden gør for at synliggøre de miljøtilpassede/etiske produkter i butikkerne og om dette er anderledes end for konventionelle produkter. Vurder hvilken særlig indsats, der evt. bliver gjort for de miljøtilpassede/etiske produkter

- Beskriv og vurder forskellene i indsatsen for de enkelte typer af produkter (økologiske, fairtrade, svanemærkede etc.). Har forskellene betydning for resultaterne?

- Beskriv hvilke varer, kæden bruger som „begyndervarer“ for de forbrugere, der vil prøve de miljøtilpassede/etiske varer af, og hvilke varer, som de mener appellerer mere til forbrugere, der allerede køber nogle miljøtilpassede/etiske varer. Er der prisdifferentiering, så begyndervarerne bliver solgt med lavere avance? (eller anden form for differentiering?) 
Kampagner

- Beskriv kædens erfaringer fra gennemførte, succesfulde kampagner (dvs. kampagner, som har givet større salg): indhold, form, samarbejdspartnere, resultater,... Vurder hvorfor de var succesfulde

- Hvilken betydning har kampagner for best practice?

Reklamer, web-sites mm.

- Beskriv hvordan de miljøtilpassede/etiske varer bliver profileret i trykte reklamer og evt. TV-reklamer. Vurder hvilken effekt reklamer mm. har på interessen for produkterne og på salget

- Beskriv hvilke andre markedsføringskanaler og -medier kæden bruger. Er noget af dette specielt for de miljøtilpassede/etiske varer?

- Vurder hvilken rolle husstandsomdelte reklamer spiller for salget af de miljøtilpassede/etiske varer. Får disse varer mere plads eller større synlighed i reklamerne end andre varegrupper? Bliver de miljøtilpassede/etiske varer brugt som tilbudsvarer? Hvorfor/hvorfor ikke?

Mcrker og anden information på produkterne

- Vurder hvilken betydning kæden tillægger dokumentation og mærkning af de miljøtilpassede/etiske varer

\section{Boks 5.2.2: Skabelon for afrapportering af butiksinterviews}

\section{Holdning og prioritering}

- Beskriv den butiksansvarliges holdning til og prioritering af de miljøtilpassede/etiske varer (skeptisk, neutral, positiv, ,ildsjæl“), og hvad han/hun anser for de væsentligste drivkræfter for afsætning af miljøtilpassede/etiske produkter. Beskriv samspillet med det centrale niveau omkring indsatsen. Hvad og hvor meget kan han/hun selv bestemme i sin butik?

- Noter data for butikkens sortiment og omsætning af miljøtilpassede/etiske varer, hvordan det har udviklet sig og hvad forventningerne til fremtiden er. Vurderer den butiksansvarlige at sortiment henholdsvis omsætning er stor, medium eller lille sammenlignet med andre butikker i kæden og med lokale konkurrenter

- Beskriv hvordan den butiksansvarlige oplever kundernes interesse for de miljøtilpassede/etiske produkter. Hvordan kommer det til udtryk, hvordan har det udviklet sig over tid og hvad gør han/hun for at konvertere interessen til større salg af de miljøtilpassede/etiske produkter?

\section{Indsatsen i butikkerne}

- Beskriv hvordan de miljøtilpassede/etiske produkter bliver gjort synlige i butikkerne (fx markering på hyldeforkanter, prisskilte, eye-catchers, placering i butikken, særligt logo/varemærke, emballage...) - samt forskellen mellem forskellige miljøtilpassede/etiske varegrupper, hvis der er en forskel. Vedlæg gerne fotos med eksempler

- Beskriv om butikken gør en særlig indsats for at synliggøre de miljøtilpassede/etiske produkter og hvad det handler om for de forskellige typer produkter (økologiske, fairtrade, svanemærkede,...) Er indsatsen permanent eller kampagnebaseret? 
- Beskriv hvad den butiksansvarlige selv anser for at være „best practice“ i for-
hold til at sælge miljøtilpassede/etiske varer og hvordan det kommer til udtryk i
hans/hendes butik - og/eller i andre butikker
- Beskriv hvad den butiksansvarlige anser for gode „,begyndervarer“ for dem, der
vil prøve de miljøtilpassede/etiske varer af, og hvilke varer, som appellerer mere
til dem, der allerede køber nogle miljøtilpassede/etiske varer. Er der prisdiffe-
rentiering, så begyndervarerne bliver solgt med lavere avance? (eller anden form
for differentiering?)

Kampagner

- Beskriv hvilke effekter, som butikken mærker af en kampagne (fx økologi, fairtrade,...), herunder hvor længe effekten varer, og hvad der kendetegner kampagner, som er gode til at få forbrugerne til at købe (flere) miljøtilpassede/ etiske varer

Mœrker og anden information på produkterne

- Beskriv hvilken betydning den butiksansvarlige tillægger mærker og andre miljørelaterede/etiske informationer på produkterne, herunder om kunderne går efter de mærkede varer

Uddannelse/trcening af butikspersonale

- Beskriv hvad den butiksansvarlige gør for at informere og uddanne sit personale til at fremme salget af miljøtilpassede/etiske varer. På hvilket niveau - skal de fx primært kunne svare på spørgsmål fra kunderne, eller skal de aktivt kunne guide kunderne frem til at foretage miljøtilpassede eller etiske valg?

- Beskriv om butikken har særlige ordninger for at motivere de ansatte til at fremme salget af miljøtilpassede/etiske produkter (fx bonusordninger, holdningspåvirkning,...)

- $\rightarrow$ Hvilke elementer af best practice er der i denne butik?

\subsection{Valg af detailhandelskæder}

Både økologi og fairtrade er i vækst i disse år, og dermed er der mange dagligvarekæder og andre butikker, som er begyndt at sælge disse produkter. I de nordiske lande sælges størstedelen af de miljøtilpassede produkter via dagligvarebutikker og andre butikker med et stort varesortiment - ikke via specialbutikker. Det er derfor relevant at undersøge, hvad dagligvarebutikkerne gør, men undersøgelsen er suppleret med non-food butikker, som gør en indsats for miljøvenlige og/eller etiske produkter.

Dagligvarebutikkerne blev valgt ud fra, at de skulle være kendte for at forhandle miljøtilpassede/etiske produkter til den brede befolkning, dvs. ikke kun til de særligt interesserede. Fx har den danske Irma-kæde en af verdens højeste andele af økologi (bortset fra specialbutikker), men kundesegmentet er primært meget kvalitets- og miljøbevidste forbrugere i og omkring København. Kæden blev valgt fra, fordi undersøgelsen gerne skulle vise best practice både overfor de meget bevidste forbrugere og 
overfor de forbrugere, der ikke lægger så stor vægt på de miljørelaterede eller etiske aspekter.

Endvidere skulle kæderne have en vis omsætning af de miljøtilpassede/etiske varer og have arbejdet med området i et stykke tid, så der var grundlag for at have opnået erfaringer i forhold til effektive virkemidler mm..

Non-food kæderne blev valgt ud fra, at de er synlige i markedet og kendte for at have miljøtilpassede produkter i sortimentet.

Det skal bemærkes, at eftersom der er tale om en forholdsvis begrænset undersøgelse målt på antallet af kæder/butikker, er der givetvis andre eksempler på best practice end dem, der indgår i denne rapport. Endvidere er salg og markedsføring dynamisk, så resultaterne i denne undersøgelse er et udtryk for, hvordan billedet var på det tidspunkt, hvor undersøgelsen blev gennemført. Om nogle år kan situationen have ændret sig, fordi detailhandelen er i en proces, hvor de opbygger viden om markedsføring og salg af miljøtilpassede og etiske produkter. På den anden side er markedsføring og salg systematisk tilrettelagt og ikke udtryk for tilfældige beslutninger, hvilket er med til at sikre en vis stabilitet.

De valgte dagligvarekceder er Coop i Danmark, Norge og Sverige. I Danmark er der gennemført interviews og besøg i to af koncernens kæder - Kvickly og SuperBrugsen. I Sverige er ICA-kæden og i Norge er Meny-Ultra-kæden desuden med. Den danskejede Netto-kæde ønskede ikke at deltage. Ud over interviewene er der i Danmark gennemført anonyme butiksbesøg og gennemgang af reklamematerialer i en række butikker: Netto, Rema 1000, Lidl, Aldi, Føtex og SuperBest. Disse besøg bidrog til at skabe en referenceramme for den egentlige undersøgelse.

Inden for non-food deltog tøjkæden Polarn o Pyret i Sverige, byggevarekæden Byggmakker i Norge samt MATAS-kæden (personlig pleje) i Danmark. Desuden er der gennemført interview på centralt niveau med IKEA Danmark med henblik på at få et indblik i strategien hos en miljøbevidst producent, som også har egne butikker.

Så vidt det har været praktisk muligt, er de besøgte butikker valgt ud fra, at den butiksansvarlige i et eller andet omfang prioriterer og har en holdning til de miljøtilpassede/etiske varer.

\subsection{Gennemførelse og afrapportering}

Interviewene og de tilhørende afrapporteringer er gennemført i perioden april-juni 2008 af 3 personer fra henholdsvis Danmark, Norge og Sverige. I de fleste tilfælde var der tale om personlige interviews, men i enkelte tilfælde er interviewene af praktiske årsager været gennemført som telefoninterviews og/eller med opfølgning per telefon.

Interviewene er optaget på bånd og efterfølgende renskrevet i henhold til skabelonen for afrapportering. De skriftlige afrapporteringer er sendt til og godkendt af de interviewede personer. Interviewene er desuden 
gennemført med løfte om anonymitet, hvilket vil sige, at det ikke af analysen fremgår hvem der gør eller har sagt hvad. Dog er der medtaget en del eksempler og fotos, og disse er godkendt af den pågældende person bag interviewet.

Projektlederen gennemgik efterfølgende alle de skriftlige afrapporteringer og skrev en foreløbig analyse på tværs af interviewene. Denne blev sendt til projektets referencegruppe og til NMRIPP-gruppen til kommentering og vurdering $\mathrm{i}$ forhold til deres respektive erfaringsområder. Kommentarer fra referencegruppen og fra de interviewede personer er efterfølgende blevet indarbejdet. Udkast til slutrapporten har ligeledes været i høring hos NMRIPP-gruppen og referencegruppen, og kommentarerne herfra er indarbejdet. 


\section{Best practice i nordisk detailhandel}

Dette kapitel præsenterer resultatet af de gennemførte, empiriske undersøgelser og giver konkrete eksempler fra de interviewede og/eller besøgte butikskæder. Kapitlet er opdelt i følgende emner:

1. Strategi, holdninger og prioriteringer

2. Salg af miljøtilpassede/etiske ${ }^{9}$ produkter

3. Viden om kunderne - sammen med kunderne

4. Internt og eksternt samarbejde

5. Medarbejderne - uddannelse og motivation

6. Den aktive markedskommunikation

7. Indsatsen i butikken

\subsection{Strategi, holdninger og prioriteringer}

Dette afsnit har følgende emner som omdrejningspunkter:

- Virksomhedsstrategi

- Sortiment og samarbejde med leverandørerne

- Marked og konkurrence

- Forbrugernes valg og motiver

- Forskelle mellem de miljøtilpassede/etiske varegrupper

- Barrierer for (videre)udvikling af det miljøtilpassede/etiske marked

\section{Virksomhedsstrategi}

Meget groft sagt kan detailhandelen på det miljøtilpassede/etiske område opdeles i leaders og followers. Leaders er pionererne, der driver udviklingen, og followers er dem, der går ind på markedet, når det har nået et vist modningsstadie og dermed indtjeningspotentiale. I denne undersøgelse har vi primært interviewet virksomheder, der kan karakteriseres som leaders, fordi det primært var i denne gruppe, vi forventede at finde gode eksempler på best practice. Followers har dog også en markedsmæssig betydning, men denne er beskrevet ud fra, hvad leaders har fortalt, og hvad det har været muligt at konstatere via reklameaviser og butiksbesøg.

\footnotetext{
9 „Miljøtilpassede/etiske produkter“ bruges i denne rapport som en fællesbetegnelse for produkter, som er udviklet med særlige hensyn til miljø og/eller sociale forhold, og som er godkendt af en uafhængig 3. part.
} 
Leaders har truffet en ledelsesmæssig beslutning og ud fra denne formuleret skriftlige politikker og strategier for indsatsen. Næsten alle de interviewede ser det som en del af deres ansvar at give kunderne en reel valgmulighed, dvs. at når kunden står i butikken, skal hun kunne vælge mellem miljøtilpassede/etiske og konventionelle produkter. Men valget er kundens, og man ønsker ikke at påtvinge kunderne et bestemt valg. Der er dog nuancer og en decideret undtagelse. Nuancerne handler om, at nogle kæder har besluttet, at visse, meget miljøbelastende produkter ikke skal være på deres hylder. Især ikke, hvis der findes mindre belastende alternativer, som er funktions- og kvalitetsmæssigt lige så gode. Undtagelsen er IKEA, som primært er producent, men som også har egne butikker. Her har man valgt ikke at give forbrugerne en valgmulighed ud fra miljømæssige eller sociale aspekter. I stedet ønsker man, at brandet står som garanti for, at produkterne og produktionsforholdene er i orden, og at virksomheden har taget hånd om det på kundernes vegne.

\footnotetext{
„IKEA mærker som udgangspunkt ikke sine produkter med specielle mærker som FSC af både praktiske og konceptmæssige grunde. Konceptmæssigt har vi valgt, at IKEA-mærket i hele verden skal være garant for, at varerne er i orden, bl.a. for at komme ud over forskellene i de nationale mærker. På det praktiske plan kan det ikke på nuværende tidspunkt lade sig gøre at få tilstrækkeligt med FSC-mærket træ til, at vi kan garantere en given produktserie worldwide. IKEA arbejder med minimumsniveauer, som gælder overalt i verden, dvs. at vi ikke ønsker at fremhæve nogle produkter frem for andre. I stedet skal kunderne vide, at når de handler hos IKEA, så er der taget miljømæssige og sociale hensyn. Det er et grundsyn i IKEAs forretningsfilosofi, og derfor er vi ikke så afhængige af, hvad kunderne synes eller ønsker i forhold til enkelte produkter“.

PR-og kommunikationsansvarlig Thomas Uhd, IKEA Danmark.
}

Det, der karakteriserer leadernes strategier, er først og fremmest holdninger og vilje til at satse på markedet for miljøtilpassede/etiske produkter som en integreret del af forretningsstrategien. Der er ikke tale om filantropi, og virksomhederne erkender, at det kræver væsentlige investeringer, og at det er en langsigtet satsning. Holdningsmæssigt ønsker man at gøre en indsats for miljø, sundhed, social ansvarlighed osv., og dette sker både ved at begrænse egne negative påvirkninger og ved at forhandle miljøtilpassede/etiske produkter. Samtidig skal det være en sund forretning, ikke blot idealisme. Kæderne ønsker at tjene penge, men også at gøre det på en miljømæssigt og etisk forsvarlig måde. Netop fordi der er holdninger bag, ønsker leaders, at kunderne skal vælge at handle miljøbevidst/etisk på to niveauer. For det første ved at beslutte sig for at handle i deres butikker, og for det andet ved at købe miljøtilpassede/etiske varer, når de er i butikken - og her skal det være let at finde varerne i butikkerne. Med andre ord forsøger kæderne at opbygge et værdifællesskab med de miljø-/etisk bevidste kunder. Samtidig understreger de, at kunder, som ikke går efter de miljøtilpassede/etiske varer, skal føle sig lige så velkomne i butikkerne, og det er stadig langt den største del af markedet. Et 
konkret eksempel på udmøntning af værdifællesskabet er, at kunderne kan få ekstra rabat eller optjene bonuspoints på de miljøtilpassede/etiske varer, hvis de har et kunde- eller medlemskort.

Leaders sørger for at løbe markedet i gang og gøre de miljøtilpassede/etiske varer tilgængelige og synlige for forbrugerne. Det kræver en stor og vedvarende informationsindsats at opbygge kendskabet til de forskellige begreber og mærker for miljøtilpassede/etiske produkter - økologi, fairtrade, svanen, osv. Efterhånden som forbrugernes kendskab, interesse og ikke mindst efterspørgsel er steget, er flere kæder gået med ind på det miljøtilpassede/etiske marked. Disse followers, heriblandt discountkæderne i dagligvarehandelen, har set, at der er et forretningsmæssigt potentiale, og de ønsker derfor at få en andel af markedet.

Followers har en markedsmæssig betydning på flere måder. Jo flere steder, de miljøtilpassede/etiske varer bliver synlige, jo mere kender forbrugerne til dem. Endvidere er followers med til at skabe volumen på markedet, hvilket igen fremmer udbuddet. Sidst, men ikke mindst, er followers med til at skabe konkurrence på markedet, både i forhold til sortimentet og i forhold til prisniveauet. Ikke mindst discountkæderne har normalt et meget begrænset fast miljøtilpasset/etisk sortiment - typisk inden for basisvarer som økologisk frugt, grønt og mejeriprodukter, fairtrade kaffe og svane- eller blomstmærket husholdningspapir. Desuden kan der i perioder være udvalgte kampagnetilbud, hvor kæden fx har købt et parti FSC-mærkede haveredskaber.

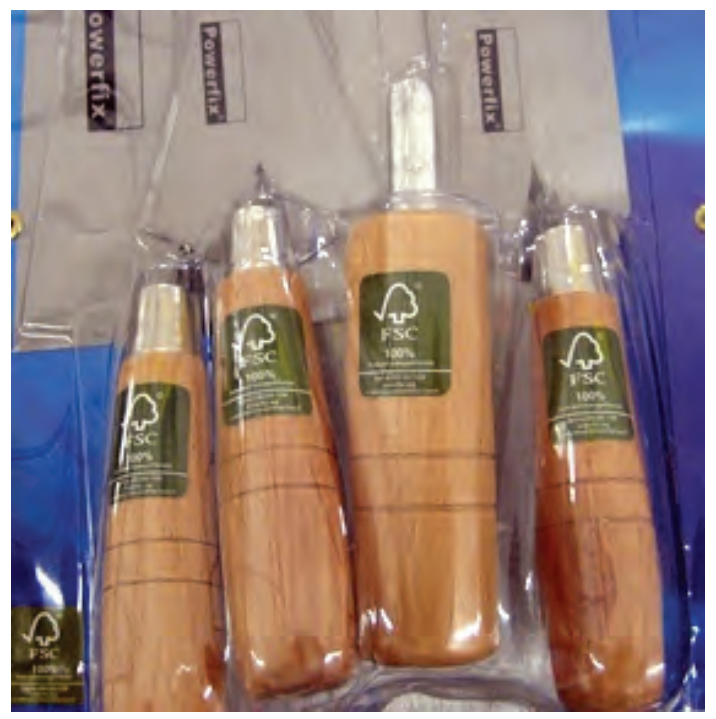

Tilbud på FSC-mœrket værktøj set hos et dansk discountsupermarked. Ugen efter fandtes produkterne ikke langere i butikken (Foto: Kirsten Schmidt). 


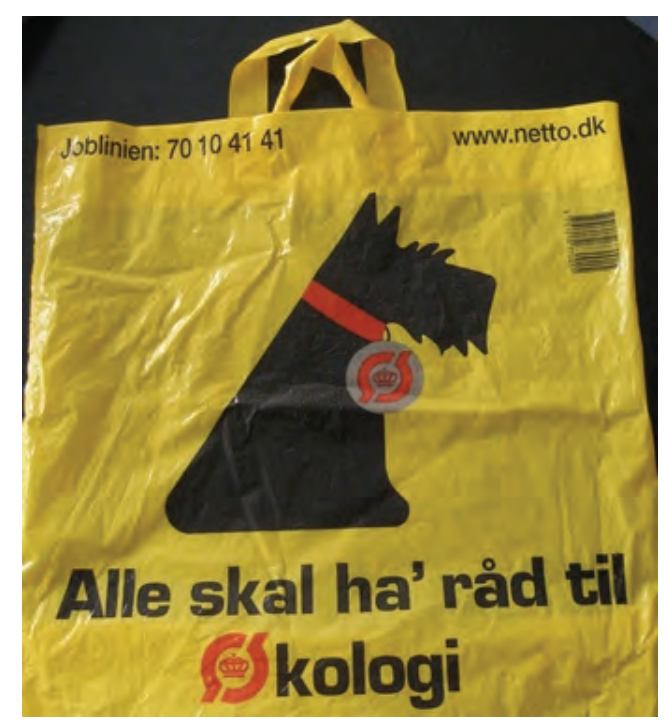

Den danskejede discountkcede Netto skiller sig ud fra de andre discountkceder ved en mere permanent satsning på økologi til rimelige priser. Under sloganet „Alle skal ha' råd til økologi“ "har Netto et fast, økologisk basissortiment. Dette sortiment er større end de andre discountkceders, men mindre end leader-kcedernes (Foto: Kirsten Schmidt).

Når først followers er med på markedet, er det ikke tilstrækkeligt for leaders at være kendt for at føre miljøtilpassede/etiske varer, og tendensen synes at gå mod, at de nu profilerer sig på at have den største bredde i sortimentet kombineret med stabilitet, dvs. at kunderne altid kan regne med at finde et vist sortiment i alle kædens butikker.

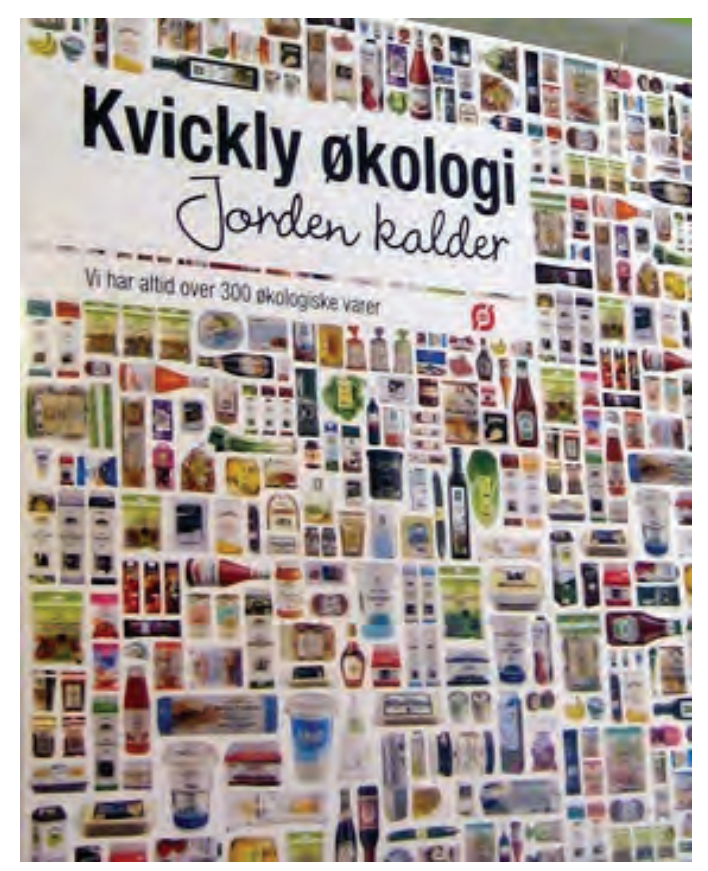

Kvickly (del af Coop Danmark) profilerer bevidst sit store, faste sortiment af økologiske varer. Som dette skilt i Kvickly, Vordingborg viser, så har Kvickly altid over 300 økologiske varer (Foto: Kirsten Schmidt). 


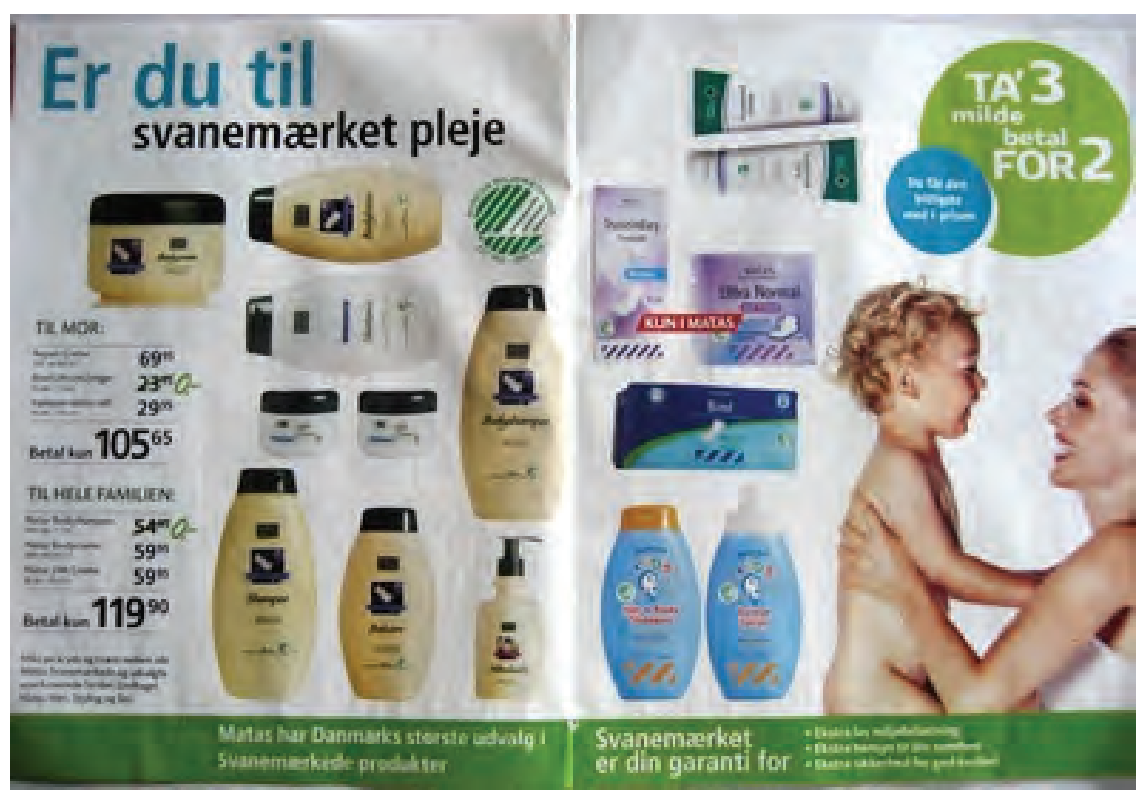

MATAS’ (Danmark) husstandsomdelte tilbudsavis fra september 2008 sætter fokus på de svanemcerkede produkter og fremhever, at MATAS har Danmarks største udvalg (Foto: Kirsten Schmidt).

Leaders synes at indgå en form for kontrakt med de miljø-/etisk bevidste forbrugere - baseret på tillid og troværdighed. Tilliden drejer sig om, at forbrugerne altid skal være sikre på, at de kan finde et godt sortiment af miljøtilpassede/etiske varer i butikkerne. Der må ikke være tomme hylder, og derfor er det meget vigtigt at have stabile forsyningskæder. Butiksbesøgene viste dog flere tilfælde af tomme hylder, hvilket indikerer, at selv om leader-kæderne lægger stor vægt på at undgå udsolgte varer i det miljøtilpassede/etiske sortiment, så kan det være vanskeligt at håndtere i praksis. Fyldte hylder er imidlertid ikke nok, de miljø-/etisk bevidste forbrugere skal også kunne få alt, hvad de har brug for i butikken, så de ikke behøver at handle flere steder. Trovœrdigheden ligger i, at kunderne skal vejledes, ikke vildledes. Der skal være solid dokumentation bag de miljøtilpassede/etiske produkter, og her er mærkerne og de organisationer, som står bag, vigtige. Leaders baserer sig på uafhængige 3. partsmærker og/eller stiller specifikke, dokumenterbare krav til deres leverandører. I det hele taget lægger leaders vægt på fagligheden på dette område. Ud over dokumentation og informationsmængde ses det ved, at de centralt i kæderne har ansat fagspecialister, der fungerer dels som drivkræfter for miljøindsatsen og dels som garanter for det faglige niveau. 
Strategien for prisscetning af de miljøtilpassede/etiske varer varierer fra kæde til kæde samt i forhold til hvilken type varer, der er tale om. Der synes således ikke at være én bestemt prisstrategi, og følgende varianter er fundet i dette studie:

- Samme avance som på de tilsvarende konventionelle produkter, hvilket i mange tilfælde betyder, at $\mathrm{fx}$ de økologiske varer er lidt eller meget dyrere. Her er tanken, at de miljøtilpassede/etiske varer selv bærer de ekstra omkostninger, der måtte være til produktudvikling, mærkning, dyrere råvarer osv.

- Samme pris for fx en miljømærket vare og en tilsvarende konventionel vare i samme produktserie fra starten, når det miljøtilpassede produkt lanceres på markedet. Her bliver meromkostningerne fordelt ud på samtlige produkter, så det ikke er prisen, der betyder noget for kundernes valg mellem den miljømærkede og den ikke-mærkede variant

- Lavere avance, som lanceres tydeligt for kunderne, så de oplever reelle prisfald på de miljøtilpassede/etiske produkter. Der er dog ikke belæg for at sige, at de dermed bliver billigere end de konventionelle, men prisbarrieren bliver væsentlig mindre eller forsvinder

- Permanente medlems- eller kundekortrabatter eller optjening af bonuspoint, dvs. at forbrugerne via et medlemskab kan opnå særligt fordelagtige priser. Det kan være på enkelte, udvalgte varer eller på et helt sortiment som økologisk frugt og grønt.

Derudover er almindelige markedsmekanismer også i spil på det miljøtilpassede/etiske område. Priserne bliver fastsat ud fra, hvad kunderne vil betale, og hvis en konkurrent sænker prisen permanent på en bestemt type varer, bliver ens egen prissætning taget op til revision for at undgå at miste markedsandele.

Tre delelementer synes at være centrale i gennemførelse af leaderstrategien: sortiment, markedsføring og synlighed i butikkerne. Sortiment-aspektet er uddybet i det følgende afsnit, mens markedsføring og synlighed i butikkerne er behandlet senere i kapitlet.

\section{Sortiment og samarbejde med leverandører}

Sortimentets størrelse og bredde har stor betydning for leaders, og sortimentet udvikles over tid baseret dels på efterspørgslen og dels på de produkter, som producenterne lancerer. I en introduktionsfase, hvor et etisk mærke skal bygges op, er sortimentet begrænset, og der er ofte fokus på produkter, der er standard i de fleste husholdninger. Disse produkter opnår en form for symbolværdi og kommer til at danne grundlaget for, hvad markedet opfatter som klassiske, miljøtilpassede/etiske produkter inden for økologi, fairtrade, svanemærkede osv. På økologi er det mejeriprodukter samt frugt og grønt; på fairtrade er det bananer, kaffe og chokola- 
de. På svanemærkede varer er der lidt mere forskel landene imellem, men vigtige varegrupper er kemisk-tekniske produkter til rengøring og vask, husholdningspapir og produkter til personlig pleje. På tværs af de forskellige miljøtilpassede/etiske produktgrupper synes der at være stor fokus på produkter til baby og børn.

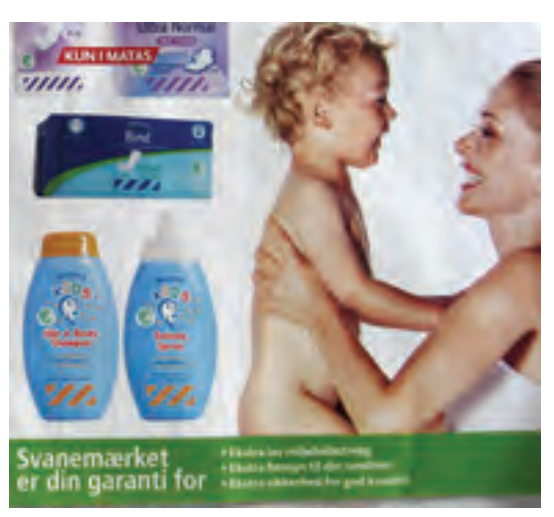

Svanemcerket børnepleje, MATAS, Danmark (Foto: Kirsten Schmidt)



Blomst-mærket babyundertøj, Kvickly, Danmark. (Foto: Kirsten Schmidt)

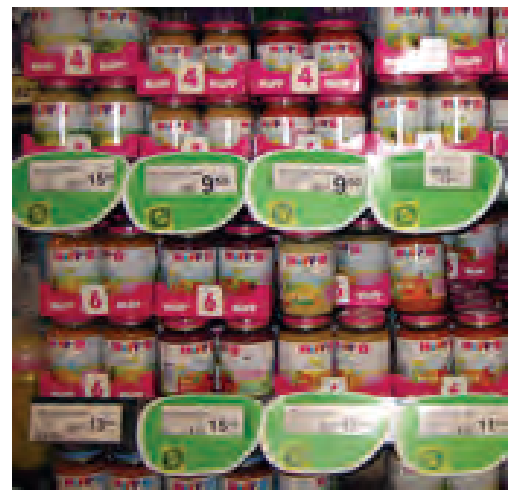

Økologisk babymad, Coop Mega, Norge (Foto: Hanne Møller)

I det mere modne marked stiger variationen i udbuddet, både i forhold til, at flere og flere produkter introduceres i en miljøtilpasset/etisk variant, og at der kommer flere varianter inden for samme produktgruppe. Endvidere er der også kommet produkter på markedet, som udelukkende findes i den miljøtilpassede/etiske variant, fx inden for kiks, kager og lignende luksusprodukter. Her er det i høj grad producenterne, der styrer udviklingen.

I det hele taget er der et tæt, men også varieret samspil mellem detailhandelen og producenterne, hvor det nogle gange er producenternes udbud, der er drivkraften, mens det andre gange er detailhandelens efterspørgsel, som driver udviklingen. Nogle eksempler er:

- Økologiske basisvarer. På områder som mælkeprodukter og frugt/ grønt er efterspørgslen så stor, at det er svært at dække markedet. Der er for få økologiske landbrug, og detailhandelen yder aktiv økonomisk støtte til omlægning og/eller samarbejder med de økologiske organisationer for at stimulere udbuddet. Samtidig er det vigtigt at fastholde et 
højt kvalitetsniveau, for kunderne køber ikke økologiske produkter, hvis de kvalitetsmæssigt er dårligere end de konventionelle

- Økologiske og fairtrade specialvarer. Disse varer henvender sig de forbrugere, der ønsker ekstra kvalitet, luksusoplevelser, eller som konsekvent køber økologisk/fairtrade. Efterspørgslen er ikke nødvendigvis stor, men produkterne er vigtige for at fastholde de miljø-/etisk bevidste forbrugere og dem, der gerne betaler lidt mere for oplevelsen af luksus. Her er det producenterne, der driver markedet ved at tilbyde nye, spændende varer, og det er vigtigt for at fastholde forbrugernes nysgerrighed

- Private labels. Nogle detailhandelskæder har egne varemærker inden for de miljøtilpassede/etiske varegrupper, og disse varemærker er en væsentlig del af kædens brand. Nogle kæder stiller særlige krav til deres egne miljøtilpassede/etiske varemærker - de skal gerne være lidt bedre og lidt billigere. De miljøtilpassede/etiske private labels varer er med til at drive udviklingen på markedet, fordi de skaber sortiment og volumen til rimelige priser

- Andre mcrkevarer. Forbrugerne ønsker ikke kun private labels, og detailhandelen har da også et stort udvalg af mærkevarer fra andre producenter - også på de miljøtilpassede/etiske varer. Nogle producenter er pionerer og udvikler hele tiden nye miljøtilpassede/etiske produkter, mens andre primært tilpasser eksisterende produkter, så de lever op til fx miljømærkekriterierne. Inden for nogle produktgrupper som husholdningspapir, shampoo og vaskepulver er miljømærkerne svanen og blomsten ved at blive standard - her er der dog nationale forskelle, idet svanen er langt mere udbredt i Sverige end i de andre nordiske lande. Men også i de andre lande vinder de svane/blomstermærkede produkter frem. De andre mærkevarer er med til at udvikle markedet, de trækker kunder til, og de er samtidig vigtige for kædernes indtjening, idet producenterne finansierer en ikke ubetydelig del af kædernes markedsføring. Leverandører af miljøtilpassede/etiske varer køber annonceplads præcis lige som alle andre leverandører

\footnotetext{
„Produktmæssigt er den fælles nordiske Änglamark-serie omdrejningspunktet for den miljøtilpassede/etiske indsats i Coop, men der er også andre miljøtilpassede/etiske varer på hylderne. Änglamark bliver også stadig vigtigere som kommunikationsplatform for miljøindsatsen“.

Miljøchef Katrine Milman, Coop Danmark
}

Sammenligner man leaders og followers på sortimentet, så har leaders klart det største sortiment, både i dybden og i bredden - i det mindste set over tid. For leaders ønsker stabilitet, så deres kunder altid kan være sikre på at finde de miljøtilpassede/etiske varer på hylderne. Followers kan godt i perioder have et stort sortiment, men så er der ofte tale om kampagner og særlige tilbud, hvor varerne ikke nødvendigvis findes i butikkerne ugen eller måneden efter. Dermed ikke sagt, at leaders ikke også 
kan have slagtilbud på særlige varer i en enkelt uge, men de lægger større vægt på at profilere det faste sortiment. Follower-gruppen er dog ikke homogen, idet nogle af disse kæder nu også opbygger et stadig større sortiment enten generelt eller inden for udvalgte produktgrupper, mens andre (typisk discountkæder) primært har slagtilbud.

Billedet er således ikke sort-hvidt, men forskellen kan illustreres ved, at for leaders indgår miljøaspektet som en væsentlig del af deres brand. Kunderne må meget gerne vælge deres butikker, fordi de har en aktiv holdning til miljø og etik, men når de er i butikken, er de velkomne til også at købe tilbud og konventionelle produkter. Followers brander sig ikke lige så tydeligt på miljø- og etiske aspekter, men når kunderne er i deres butikker, må de meget gerne også vælge at købe miljøtilpassede/etiske varer inden for det sortiment, som butikken nu har.

De miljøtilpassede/etiske alternativer er vigtige at få ud på markedet, for det er kun meget få kunder, der er så idealistiske, at de helt fravælger at købe et ønsket produkt, hvis de kun kan få en konventionel variant.

\section{Marked og konkurrence}

Markedet for de miljøtilpassede/etiske varer er kraftigt stigende i disse år. Alle de interviewede melder om høje stigningstakter og forventer, at det fortsætter, fordi markedet ikke synes at være mættet endnu, og fordi det er økonomisk gunstige tider, hvor forbrugerne har råd til at bruge penge på de ofte dyrere miljøtilpassede/etiske varer. De høje stigningstakter skal dog ses ud fra, at markedsandelene stadig er ret små med undtagelse af enkelte produktgrupper. Den stigende efterspørgsel går både i dybden og i bredden: der bliver solgt flere forskellige miljøtilpassede/etiske varer og mere af de enkelte varegrupper. Der er således plads til, at followers kan komme ind på markedet uden at leaders mister omsætning.

Lokal konkurrence er ikke negativt, men på den anden side er det bestemt en mulighed, at kunderne shopper efter gode tilbud - også når det gælder miljøtilpassede/etiske varer. Dem, der går efter miljøtilpassede/etiske produkter, er ikke nødvendigvis mere mærkeloyale end andre de går også gerne efter de billigste varer.

Der synes at være nationale forskelle på indstillingen til at samarbejde med konkurrenter om at udvikle det miljøtilpassede/etiske marked. I Danmark og Sverige samarbejder man kun indirekte i form af at deltage i kampagner, som gennemføres af myndigheder eller organisationer, $\mathrm{fx}$ Miljømærkesekretariater, Fairtrade eller andre organisationer. I disse kampagner er det primære formål information, dvs. at fremme kendskabet til et givet mærke, hvilket alle parter har en naturlig interesse i. Derudover gennemfører detailhandelen ikke fælles kampagner, men har hver deres markedsføringsindsats, og det kan skyldes, at der er få, meget stærke leaders, som ikke har nogen interesse i at hjælpe konkurrenterne ind på banen. I Norge er de største kæder gået sammen om kampagner, der skal 
fremme kendskab og synlighed for økologi, og her gennemfører man bl.a. også fælles markedsundersøgelser. Årsagen til, at samarbejdet mellem kæderne i Norge er lidt mere omfattende kan muligvis skyldes, at der ikke er eller har været en/få dominerende kæder på dette område, og at detailhandelen er kommet senere i gang i Norge end i de andre lande.

\section{Forbrugernes valg og motiver}

Der er i de senere år gennemført en del undersøgelser, der viser, at forbrugerne ønsker at handle miljøbevidst/etisk, men interessen slår langt fra igennem, når de står i butikkerne. Her er det stadig pris og vaner, der bestemmer. Ikke desto mindre er det miljøtilpassede/etiske marked stigende, og stadig flere forbrugere køber faktisk produkter, som er svanemærkede, økologiske, fairtrade osv.

„Hos ICA jobbar vi mot kunder genom att forsöka hålla et lågt pris och stimulere dem som vill handla etisk. Det finns en stor potential i denna marknad och kunderna blir mer och mer villiga att ta större ansvar för vilka produkter de köber“. Manager Environment and Social Responsibility, Kerstin Lindvall, ICA

„Det är en ekotrend på gång nu, och det fanns en ekotrend på 90-tallet, men den dog ut iblandt för det att kollektionen då var ganska tråkig og beige. De produkter, vi säljer nu, er i stället i linje med övriga produktudbud och kunderna har inte behövt göra några avkall på kvalitet och design. Det er nog nycklen till att vi ska kunna fortsätta denna gången“.

CSR-ansvarlig Mimmi Brodin, Polarn o. Pyret

Med begreber lånt fra detailhandelen skelner denne undersøgelse mellem det blå segment og det grønne segment. De blå er forbrugere, som ikke er specielt miljø-/etisk bevidste, men som godt vil prøve fx økologiske produkter, hvis det ikke koster dem for meget i penge, kvalitet, besvær eller andet. De grønne er de miljø-/etisk bevidste forbrugere, som stabilt, men ikke nødvendigvis udelukkende, køber miljøtilpassede/etiske produkter, og som gerne udvider deres forbrug til stadig flere produktgrupper, også selv om det koster mere. Nogle leader-kæder arbejder meget bevidst med denne segmentering i markedsføring, prissætning og synlighed i butikkerne, hvilket bliver uddybet senere i rapporten. Overordnet set handler det om at få „de blå“ til at prøve de miljøtilpassede/etiske produkter af, og få „de grønne“ til at købe endnu flere miljøtilpassede/etiske produkter.

Forbrugerne har varierede motiver til at handle miljøbevidst eller etisk, hvilket interviewene i denne undersøgelse bekræfter. Men nogle aspekter går igen. For det første er der baby-faktoren. Det at få børn betyder en mindre revolution, også i valget af produkter. Baby skal beskyttes og ikke udsættes for unødvendige parfumer, tilsætningsstoffer, kemikalier mm., så børnefamilierne er en meget vigtig målgruppe på det miljøtilpassede/etiske marked. Men det, at mor handler uparfumerede produkter til sine børn, betyder ikke, at hun holder op med at købe parfumevarer til sig 
selv. Tværtimod er markedet for velværeprodukter til krops- og ansigtpleje stigende, og her er der stadig mange forbrugere, som ikke stiller spørgsmål til indholdsstofferne.

Et andet aspekt er, at miljøhensyn ikke på nuværende tidspunkt bliver brugt som et selvstændigt markedsargument. Dette er i modsætning til fx Storbritannien, hvor transportform og klima bliver brugt direkte i markedsføringen. Den nordiske detailhandel vælger generelt at kombinere miljøaspekter med andre argumenter, $\mathrm{fx}$ sundhed og ekstra god kvalitet. Klimamærkning bliver dog diskuteret også i Norden, og den svenske kæde Max Burger klimamærker deres produkter.

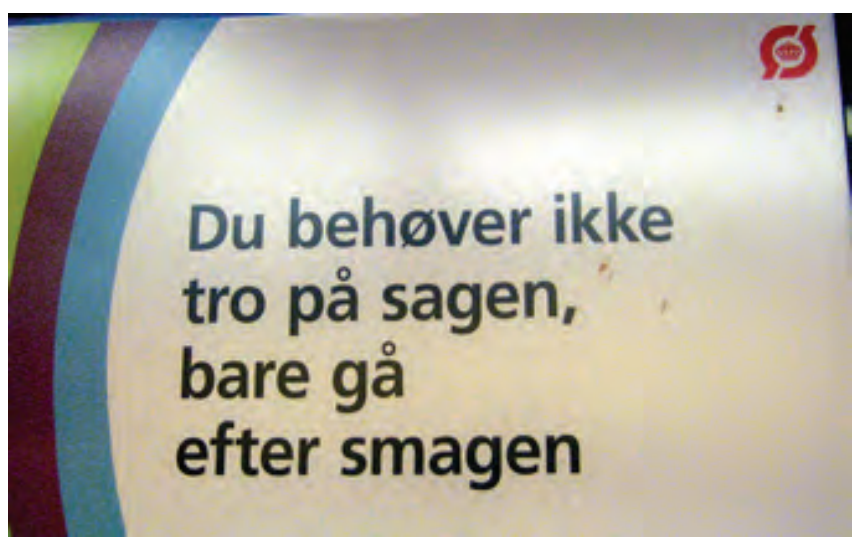

Skilt set ved køledisken med økologisk kød i en dansk SuperBrugsen (Foto: Kirsten Schmidt)

Inden for nogle varegrupper er de professionelle indkøbere desuden en større drivkraft på udvikling af det miljøtilpassede/etiske marked end de private forbrugere.

„For Byggmakker kan kunden være store entreprenører. De skal lage anbud/kontrakter og i disse inngår miljø med en vektet \%-andel. Statsbygg som kunde setter store krav til bruk af miljøvennlige løsninger, og derfor er satsning på miljøvennlige produkter vigtig“.

Miljøansvarlig Terje Lœrum, Byggmakker.

\section{Forskelle mellem de miljøtilpassede/etiske varegrupper}

I interviewene er der spurgt til, om detailhandelen prioriterer de forskellige miljøtilpassede/etiske varegrupper (økologi, fairtrade, svanemærkede, FSC-mærkede, MSC-mærkede) forskelligt. Der synes ikke at være en bevidst prioritering af nogle af disse grupper frem for andre, men der er en række forhold, som spiller ind på prioriteringen.

For det første handler det om, hvad der kom først i forhold til at opnå et vist gennembrud på markedet, og her er der nationale forskelle. I Danmark var det økologi, og det smitter stadig af på den måde, at den økologiske markedsandel er størst i Danmark, og det er de økologiske produkter, der bliver mest fremhævet i supermarkederne. Fx bliver der sat skilte 
op ved de økologiske produkter, men ikke ved de svane/blomstmærkede - med mindre der er en særlig kampagne. Der synes heller ikke at være en ændring på vej på dette område, bl.a. fordi man ikke ønsker at skabe informationsoverload ved at mange varer bliver specielt fremhævet. I stedet satser en kæde som Coop Danmark på at synliggøre deres eget, miljørelaterede varemærke - „Änglamark“.

Især i Sverige, men også i Norge kom der først fokus på miljømærkning, og svanemærket bruges aktivt i skiltningen. Nu er økologi og fairtrade imidlertid kommet så meget $\mathrm{i}$ fokus, at disse produkter også bliver fremhævet via særlig skiltning, og det synes ikke at være et problem i disse lande. I denne undersøgelse indgår en overvægt af supermarkedskæder, og det kan spille ind, idet supermarkeder har en væsentlig del af deres omsætning på fødevarer, og derfor vælger at prioritere disse - og dermed økologi - selv om det kan føre til mere omfattende skiltning.

I Norge er der udbredt skepsis over for FSC-ordningen, som ikke bliver anset som troværdig garanti for, at forpligtelserne bliver efterlevet det er for let at købe sig til et certifikat. Bl.a. afviser Byggmakker-kæden at godtage FSC og i det hele taget at sælge produkter, hvor der indgår truet regnskovstræ.

\footnotetext{
„Årsakene til mer satsning på økologiske varer er at Meny satser på ferskvarer og dette henger fint sammen med den økologiske profilen. For miljømerkede produkter er det mest non-food produkter, som ikke har like stort fokus hos Meny. For denne typen av produkter har også produsenten ett ansvar i større grad“.

Kategoriansvarlig Kenneth Lindland, Meny-Ultra.
}

Et andet aspekt er, at det tager meget lang tid at opbygge forbrugernes kendskab til et mærke. Der skal store mængder information over flere år til, så de markedsmæssigt „nyere“ mærker som fairtrade, FSC og MSC har stadig lang vej at gå.

\footnotetext{
„Kunnskapen kring rättvisemärkt är lägre än för ekologiska varor. Det gällar att rikta in sina insatser mot mer kunskapsmarknadsföring, og det är viktikt att visa på att produkten är tillverkad under sjysta arbetsförhållanden och visa på sådana saker som gör at kunderna förstår varför det kostar mer pengar och att de känner att det är värt att betala det högra priset“.

Manager Environment and Social Responsibility, Kerstin Lindvall, ICA.
}

I de første år, mens kendskabet er lavt, er usikkerhederne større i forhold til mulig omsætning, og det er i denne opbygningsfase, at behovet for synlige kampagner er størst. Her er samarbejde med organisationer, myndigheder og andre vigtigt.

\section{Barrierer for (videre)udvikling af det miljøtilpassedeletiske marked}

Lige nu er der så meget vækst på det miljøtilpassede/etiske marked, at nogle af de interviewede siger, at der egentlig ikke er nogen barrierer, for 
man kan dårligt nå at fylde varer på hylderne før de bliver tømt igen. Der bliver dog peget på en række udfordringer for (videre)udvikling af det miljøtilpassede/etiske marked.

Først og fremmest manglende kendskab hos forbrugerne og hos de ansatte i butikkerne. Vejen frem er information og mere information. Dernæst kan det på nogle områder - især økologi - være svært at skaffe varer nok til at dække efterspørgslen. Det tager fx tid at omstille til økologisk landbrug.

En tredje faktor er prisen. Nogle miljøtilpassede/etiske varer er noget eller meget dyrere end de konventionelle. Hvis man skal betale 3-4 gange mere for en økologisk kylling frem for en konventionel, skal man være meget overbevist som forbruger. I disse år er købekraften blandt forbrugerne stor, og dermed er betalingsvilligheden også til stede, specielt hvis man oplever en merværdi. Omsætningen af de miljøtilpassede/etiske varer er størst, hvor prisdifferencen er mindst, og her behøver detailhandelen på nuværende tidspunkt ikke at gøre en særlig indsats. Omvendt skal der mere til for at sælge de dyrere produkter.

\subsection{Salg af miljøtilpassede/etiske produkter}

Emnerne i dette afsnit er:

- Omsætning

- Best practice for salg af de miljøtilpassede/etiske produkter

- Fra strategi til handling i butikkerne

\section{Omscetning}

Nogle detailkæder oplyser data for omsætning, mens andre ikke gør. Alle melder om stor stigning inden for økologi og fairtrade, selv om den samlede markedsandel for disse produkter stadig er begrænset. Visse produkter har dog meget store markedsandele. Salget af de svanemærkede produkter stiger også og har pæne markedsandele på nogle produktområder. Det stigende salg går både i dybden og i bredden: der bliver solgt flere typer miljøtilpassede/etiske produkter, og flere inden for de enkelte produktkategorier.

Der er en trend i tiden, der stimulerer efterspørgslen efter de miljøtilpassede/etiske varer, og det får også detailhandelen til at sætte ekstra fokus på området. Nogle kæder melder, at de nærmest ikke behøver at gøre noget særligt for at få et stigende salg, men at de benytter lejligheden til at styrke deres brand inden for det miljømæssige/etiske område. Kæderne forventer, at det ikke blot er en forbigående trend. Kunderne har fokus på miljø, sundhed, dyrevelfærd, børnearbejde mm. - medierne har også fokus på det, og så må man som detailhandler være med på banen. 
Stigende (fødevare)priser og faldende købekraft kan dog godt få en betydning for det miljøtilpassede/etiske marked. En af de interviewede butikschefer vurderede situationen på følgende måde:

\footnotetext{
„Vi kan mærke, at folk har færre penge nu, men de køber stadig økologisk. De bruger samme beløb som før, men de får færre enheder for pengene. Det gælder alle varer, ikke kun de miljørigtige. Nogle kunder vælger at holde fast i deres økologiske favoritter, og så sparer de og køber discount på andre områder. Vi kan også se, at vi sælger mest økologi først på måneden og mindst sidst på måneden, indtil der kommer løn på kontoen igen“

Uddeler Qasiar Khan, SuperBrugsen, Nørrebro.
}

\section{Best practice for salg af de miljøtilpassede/etiske produkter}

For at fastholde kundernes interesse og få endnu flere til at købe de miljøtilpassede/etiske varer, er der behov for at fastholde fokus via kampagner, som udbreder kendskabet til de forskellige mærker, og frem for alt via synlighed - både i markedsføring og i butikkerne. Der skal med andre ord være en aktiv markedskommunikation om de miljøtilpassede/etiske produkter, for kunderne køber stadig ikke så mange af disse produkter, som de siger, at de gerne vil. Ud over kendskab og synlighed, indgår pris og sortiment i best practice sammen med de ansattes vidensniveau og indstilling. Endelig peger butikkerne på betydningen af „Jungletelegrafen“, dvs. mund-til-mund metoden, hvor det rygtes, at butikken har et særligt godt sortiment af miljøtilpassede/etiske produkter, eller at bestemte produkter er særligt gode.

Synlighed i butikkerne opnås på flere måder, hvilket er illustreret i afsnit 6.7. Overordnet set handler det om at have et stort varesortiment, at placere varerne, hvor de er mest synlige for kunderne og at stimulere kundernes nysgerrighed. Det kan fx være lancering af nye produkter, ved at flytte rundt og fremhæve forskellige produkter over tid eller ved at samle produkterne, så forbrugerne får øjnene op for bredden i sortimentet. Her har de store butikker et fortrin frem for de små butikker, dels fordi de har plads til en større bredde i sortimentet, og dels fordi de har flere iøjnefaldende pladser, hvor varerne kan fremhæves.

\footnotetext{
„Nøgleordet for salg af økologi er volumen: der skal være masser af plads og mange varer. Det har vi her, og det kan mærkes“.

Varehuschef Morten Houmann, Kvickly, Vordingborg
}

Varesortiment og synlighed skal appellere både til det blå og til det grønne forbrugersegment. Kæderne har forskellige måder at gøre dette på, og der kan også være varianter inden for den enkelte kæde alt efter geografisk lokalisering (de miljøtilpassede/etiske varer står generelt stærkest i storbyerne) og mulighederne i den enkelte butik. Der synes at være en tendens til, at butikkerne søger at fange de blås interesse ved at have basisvarer til en fornuftig pris og kvalitet. Disse varer er placeret synligt ude 
blandt de konventionelle varer, så kunderne ser dem, når de ønsker at købe den pågældende type produkt.

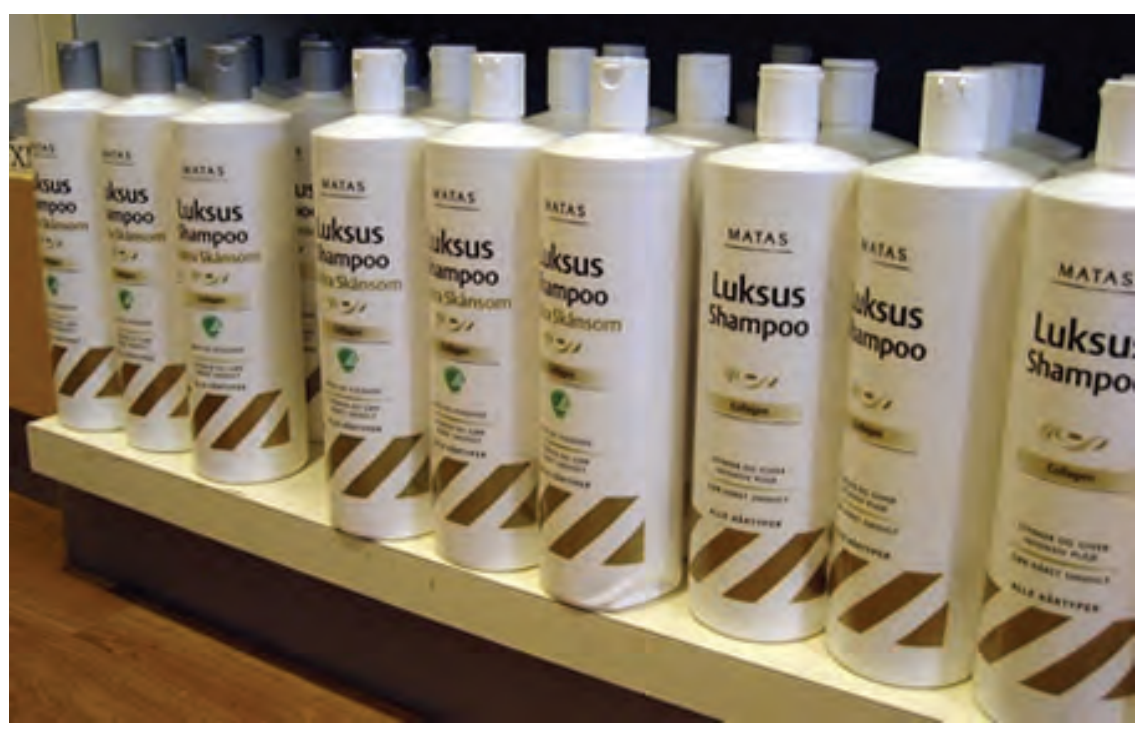

MATAS, Danmark, forhandler 3 varianter af deres luksusshampoo - en konventionel, en svanemcerket og en svanemcrket uden parfume. Alle 3 varianter står samlet, og prisen er den samme (Foto: Kirsten Schmidt).

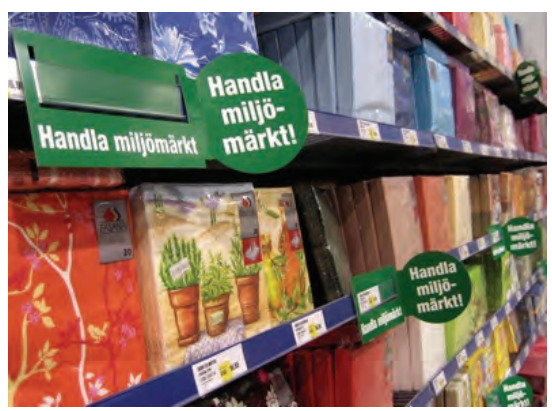

Servietreolen hos City Gross, Kalmar i Sverige. De miljømcrkede varer er tydeligt markede i det samlede sortiment (Foto: Kirsten Schmidt.)

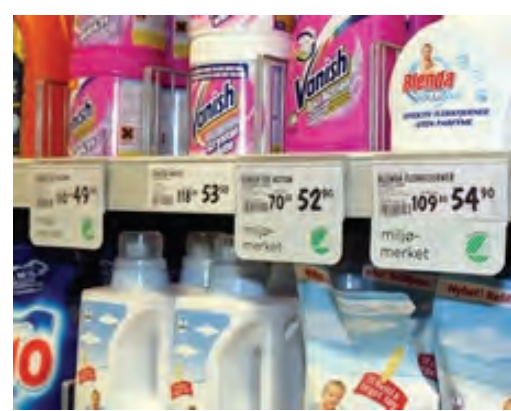

Svanemcerkede produkter blandt øvrige produkter hos Meny, Fredrikstad, $i$ Norge (Foto:Meny-Ultra).

Til de grønne, som mere bevidst går efter de miljøtilpassede/etiske varer, skal der være bredde i sortimentet, og der skal løbende introduceres nyheder, så interessen bliver yderligere stimuleret. Samtidig vurderer nogle, at det er en fordel at samle sortimentet, så kunderne kan se, at de også kan købe meget andet i en miljøtilpasset/etisk variant, end de lige var klar over. Det fører til mer-køb, bl.a. fordi de grønne er villige til at betale lidt mere for en miljøtilpasset/etisk variant. Andre vurderer, at det er for omkostningskrævende at have en sådan dobbelteksponering af varerne. Visse varer er af praktiske årsager bundet til at være i kølediske eller andet, men her er de miljøtilpassede/etiske varianter så samlet og synliggjort i en særlig sektion. 
I supermarkederne er strategien med at samle varerne i et specielt område mest udbredt på det økologiske område, men der er overvejelser om at gøre det samme på fairtrade.

„Vi har nu besluttet, at fairtrade produkterne ligeledes skal samles på en reol sammen med de økologiske produkter. Det er sådan, at varer sælger varer, så når kunden går efter en vare og opdager nye muligheder, så tager hun dem med“.

Marketingchef Tine Guldborg Bredvig, SuperBrugsen.

Strategien bruges også i non-food specialbutikkerne, hvor det ikke nødvendigvis handler om økologi. I Norge har man tidligere uden held haft det økologiske sortiment samlet, men ved at sprede det ud har man opnået et større salg. Set gennem en „blå forbruger versus grøn forbruger“ optik, kan den manglende succes hænge sammen med, at man fra starten henvendte sig til et grønt segment, men at forbrugerne befandt sig i det blå segment.



Økologiske mejerivarer samlet i en særlig sektion af kølemontren. Kvickly i Vordingborg, Danmark (Foto: Kirsten Schmidt)

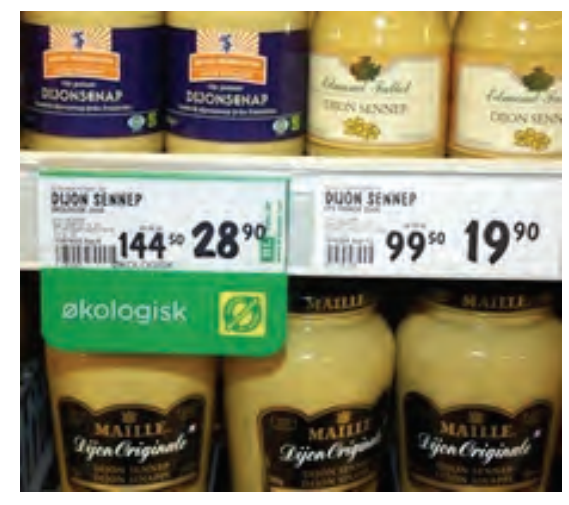

Økologiske varer blandet med konventionelle varer. Meny, Fredriksstad, Norge.(Foto:Meny-Ultra.).

Samlet set kan man sige, at ved at samle varerne skaber butikken synlighed og breder salget ud, og ved at have de miljøtilpassede/etiske varer ude blandt de konventionelle, stimuleres kundernes nysgerrighed i forhold til at prøve den miljøtilpassede/etiske variant. Den miljøtilpassede/etiske variant kan også blive valgt af andre årsager end at den er økologisk, svanemærket mm. (fx et særligt design på en tøjkollektion, en særlig duft i en creme osv.), lige som nogle kunder køber de miljøtilpas- 
sede/etiske varer ved en tilfældighed, dvs. uden at de har foretaget et bevidst valg om, at de ønskede netop sådan en variant.

\section{Fra strategi til handling i butikkerne}

Opsummerende om hvordan leader-kæderne omsætter deres strategier til handling i butikkerne, kan man sige, at det handler om:

- at have et stort og stabilt sortiment, som retter sig både mod de blå og de grønne

- at udvikle og forny sortimentet løbende, men fastholde høj kvalitet, så kunderne oplever en merværdi

- at prissætte varerne, så prisen ikke generelt opleves som en barriere

- at gøre sortimentet meget synligt i butikkerne

- at uddanne og motivere personalet til at prioritere de miljøtilpassede/ etiske varer og til at gå i dialog med kunderne

- at have en aktiv markedskommunikation både før kunderne kommer i butikken, og når de er der

\subsection{Viden om kunderne - sammen med kunderne}

Afsnittet har to omdrejningspunkter:

- Vidensopbygning om det miljøtilpassede/etiske marked

- Uddannelse og engagement af kunderne

\section{Vidensopbygning om „det miljøtilpassede/etiske marked“}

Når kæderne skal vurdere kundernes præferencer, er salgsstatistikkerne formentlig den mest udbredte informationskilde, specielt i forhold til, hvad kunderne reelt køber og ikke køber. Denne information bliver blandt andet brugt til at styre indkøb og sortiment, men også varernes placering i butikkerne. Varer, som står på fremtrædende pladser, sælger godt, og det bliver bl.a. udnyttet til at sætte fokus på udvalgte produkter. Denne undersøgelse tyder på, at supermarkederne har særlige opgørelser, når det handler om økologi, men ikke nødvendigvis for de andre miljøtilpassede/etiske varekategorier. Her opgøres salget på varenumre, men det er ikke altid, man kan se, om et givet varenummer dækker over et miljøtilpasset/etisk eller et konventionelt produkt.

Til gengæld siger salgsstatistikkerne ikke direkte noget om eventuelt udækkede behov. Her bruger detailhandelen markedsundersøgelser, fokusgrupper, testpaneler mm., lige som på andre produktområder. Emnerne kan være alt fra idéer til nye produkter, test af produkter under udvikling, prissætning, service osv. Der bliver generelt ikke gennemført særli- 
ge markedsundersøgelser for de miljøtilpassede/etiske varer, men der kan være spørgsmål om disse produkter med i de overordnede markeds- eller kundetilfredshedsundersøgelser. Kundernes respons bliver brugt både som pejlemærke for sortiment, informationsniveau, tilgængelighed i butikkerne, prisniveau og meget andet. I Norge er de store supermarkedskæder gået med i Varehandelens Økogruppe, som får udarbejdet et årligt Økobarometer om kundernes økologiske præferencer og reelle køb.

\section{Økobarometer 2007}

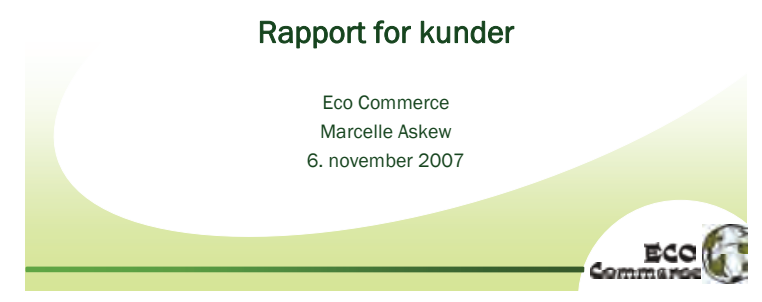

\section{Formål}

Årlig adferds- og holdningsundersøkelse om økologisk mat

- Få frem konkret informasjon om hva som skal til for at forbrukere handler (mer) økologisk mat.

- Følge og analysere trender over tid.

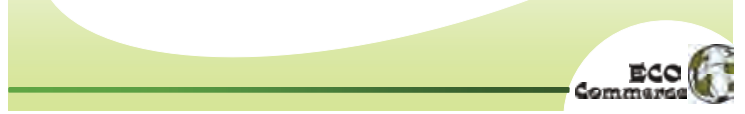

OH's fra præsentation af 2007-udgaven af Økobarometeret

Desuden følger kædernes ansvarlige for miljøområdet med i udviklingen generelt, fx via undersøgelser, som bliver gennemført af miljømærkesekretariaterne, NGO'er og andre organisationer, samt hvad der kommer op i medierne. NGO'erne fungerer i et vist omfang også som forbrugernes talerør via dialog og samarbejde med kæderne. Relevant viden bliver formidlet videre til kædernes markedsafdelinger, og tilsvarende bliver butikkernes viden om kundeønsker, præferencer, klager og andet formidlet videre til det centrale niveau i kæderne. En aktiv to-vejs dialog mellem kæderne og markedet og mellem det centrale niveau og butikkerne har betydning både for, hvor hurtigt de miljøtilpassede/etiske varer slår igennem på markedet, og for leadernes muligheder for at forblive leaders. 
Medierne har en tydelig funktion i forhold til at sætte dagsordenen på det miljø- og etisk relaterede område, og det gælder både positiv og negativ omtale. Kunderne fokuserer meget på det, der er oppe i medierne, så de interesserer sig ikke kun for (miljø)mærker, men lige så meget for enkeltområder som parfumer, parabener mm.. En artikel kan godt føre til mange spørgsmål i butikken, men effekten er kortvarig med mindre emnet bliver fulgt op i medierne.

\section{Uddannelse og engagement af kunderne}

Kundernes vidensniveau er af meget stor betydning for salget af de miljøtilpassede/etiske produkter, og det er måske her, en af de største forskelle er sammenlignet med de konventionelle produkter. Derfor bruger detailhandelen mange ressourcer på information, og det sker på mange måder, både før kunderne kommer i butikken og i selve butikken. Alle kæderne har hjemmesider med mere eller mindre omfattende information om kædens holdninger og indsats samt om det miljøtilpassede/etiske varesortiment.

Som eksempler kan nævnes, at Coop S udarbejder hæfter om økologisk landbrug og at flere butikker deler smagsprøver ud i butikkerne, så kunderne kan prøve produktet.

„Ind i mellem uddeler vi smagsprøver på økologiske produkter - typisk i forbindelse med kampagner. Desuden gør vi det her i butikken, at hvis vi har overskud, så vælger vi at bruge noget af det på at skabe mere synlighed og uddele smagsprøver. Især af økologisk kød, som er rigtig lækkert, og det vil vi gerne have forbrugerne til at prøve“.

Uddeler Qasiar Khan, SuperBrugsen, Nørrebro.

Coop DK (Kvickly) har udarbejdet en kogebog med økologiske retter, og den sælges billigt i butikkerne sammen med de økologiske varer.

„Idéen bag bogen er at vise vores kunder, at der findes flere økologiske varer i Kvickly end mange umiddelbart tror, og at hele måltider kan tilberedes udelukkende ved brug af økologiske produkter“.

(Citat fra bogen) 

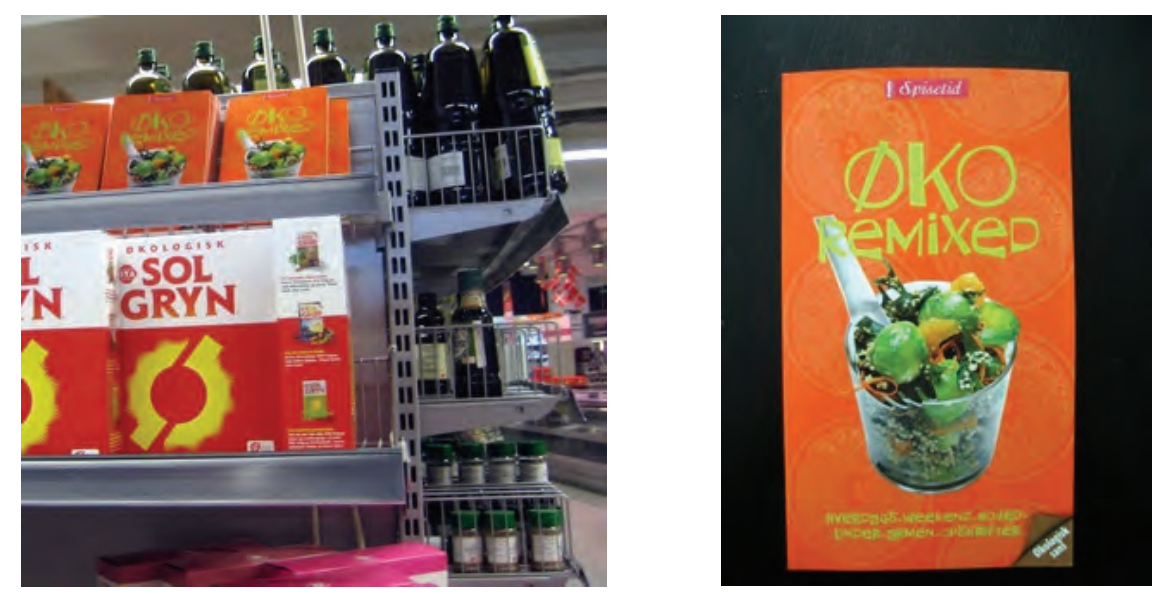

Kvicklys økologiske kogebog er udarbejdet i samarbejde med Økologisk Landsforening og madskribenten Tina Scheftelowitz. Dermed er den også et eksempel på, at kendte kokke/madskribenter er med til at profilere de økologiske fødevarer (Fotos: Kirsten Schmidt).

I reklameaviser, på skilte i butikkerne og på kædernes hjemmesider bliver det forklaret, hvad økologi, svanemærket, fairtrade osv. står for. Coopkæderne benytter også medlemsbladene til at informere om de miljøtilpassede/etiske varer. Herunder er vist en række eksempler på, hvordan informationerne formidles.

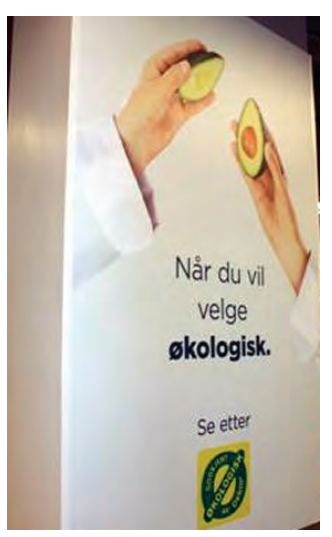

I Norge har Meny-Ultra kceden prioriteret et klart og enkelt budskab, der handler om at slå kendskabet til økologi-merket fast. De store skilte er placeret rundt om i butikken $i$ ncrheden af de økologiske produkter (Foto: Meny-Ultra). 


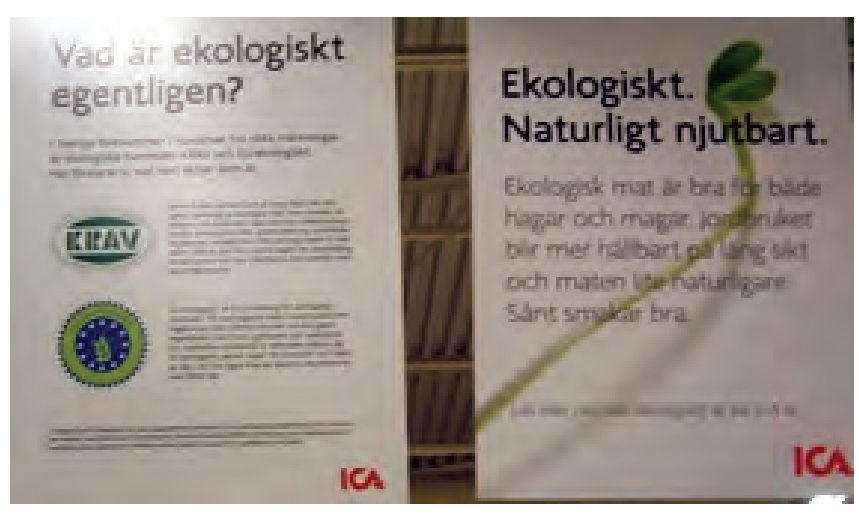

(Foto: Christian Lindskog.)

Store skilte ophængt i ICA MAXI, Mölndal i Sverige. Skiltene hænger ned fra loftet over reolerne med økologiske varer og forklarer, hvad økologi er samtidig med, at økologimærkerne bliver vist

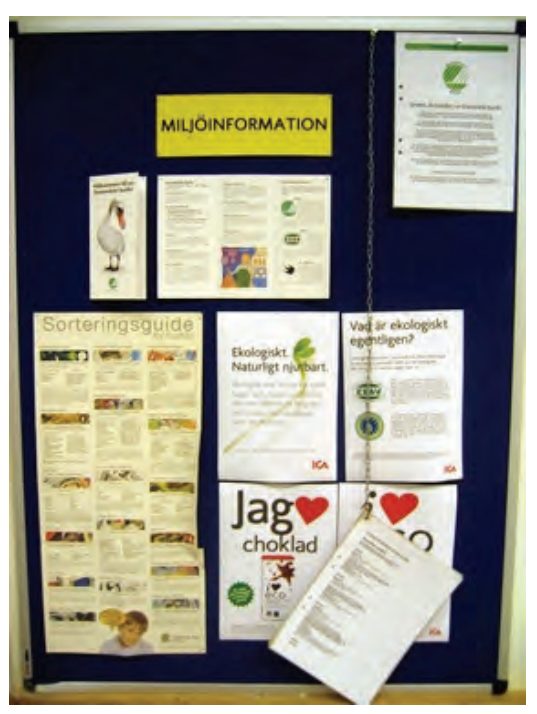

(Foto: Christian Lindskog).

ICA MAXI har ligeledes en kundeinformationstavle i nærheden af indgangen til butikken, hvor der er en sektion med miljøinformation. Denne information handler både om forklaring af mærker og begreber - og om praktiske handlingsanvisninger, her i form af en sorteringsguide for affald 


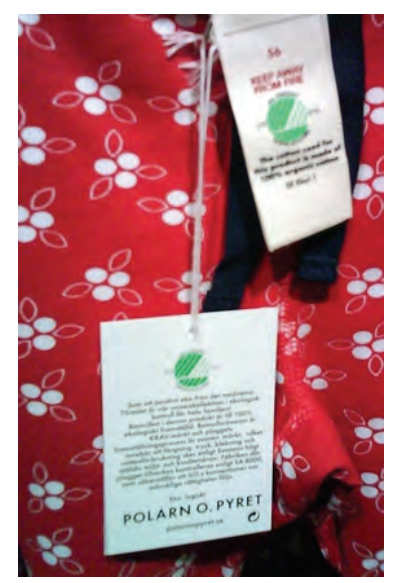

På Polarn o. Pyrets økologiske tøjkollektion er der sat skilte på tøjet med forklaring om miljøtilgangen. Af skiltet fremgår at:

- $\quad$ tøjet er svanemæerket samt information om hvad det betyder, specielt i forhold til kemikalier

- $\quad$ der er brugt KRAV-certificeret bomuld

- $\quad$ tøjet er produceret under kontrollerede forhold i henhold til SA 8000 standarden og ILO's konventioner (Foto: Christian Lindskog)

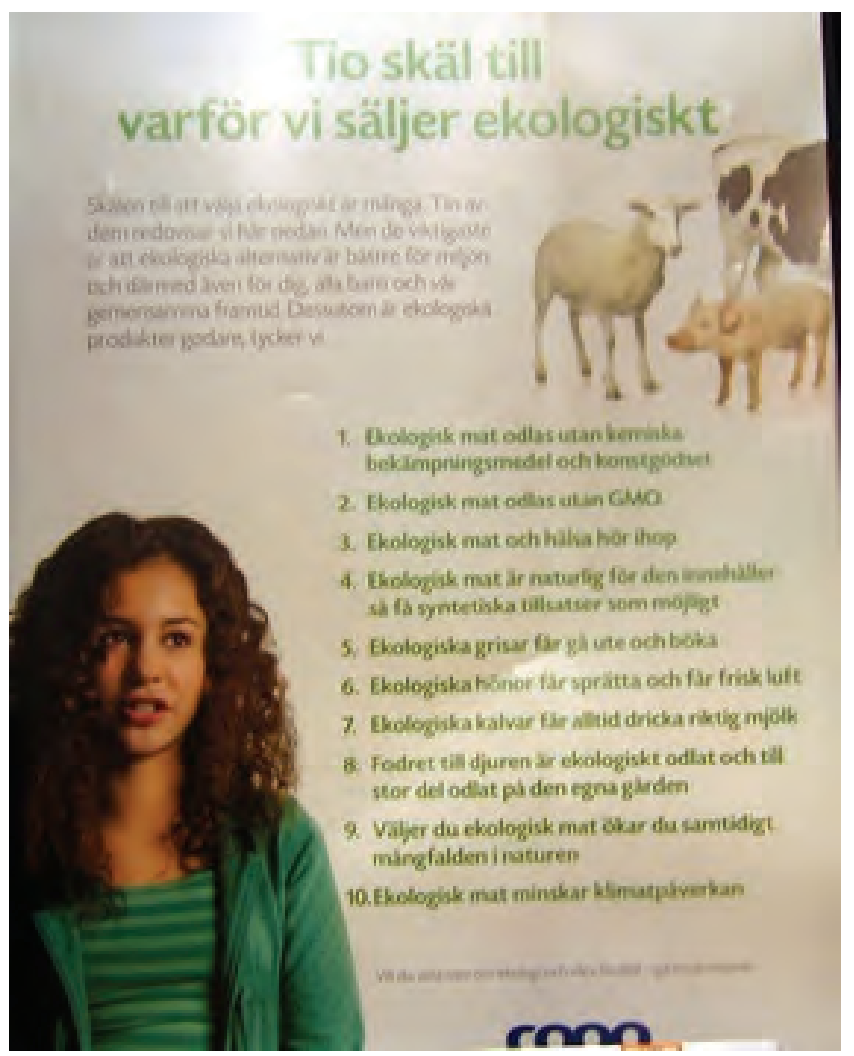

Coop, Sverige har valgt en holdningsbaseret tilgang til informationen. Ved at forklare hvorfor Coop scelger økologiske varer bliver det samtidig forklaret, hvad økologi er. Dette er også et eksempel på information, som ikke sigter på at illustrere og forklare et mcerkelet logo, men derimod fordelene for dyr og mennesker ved den økologiske produktionsmetode (Foto: Christian Lindskog). 


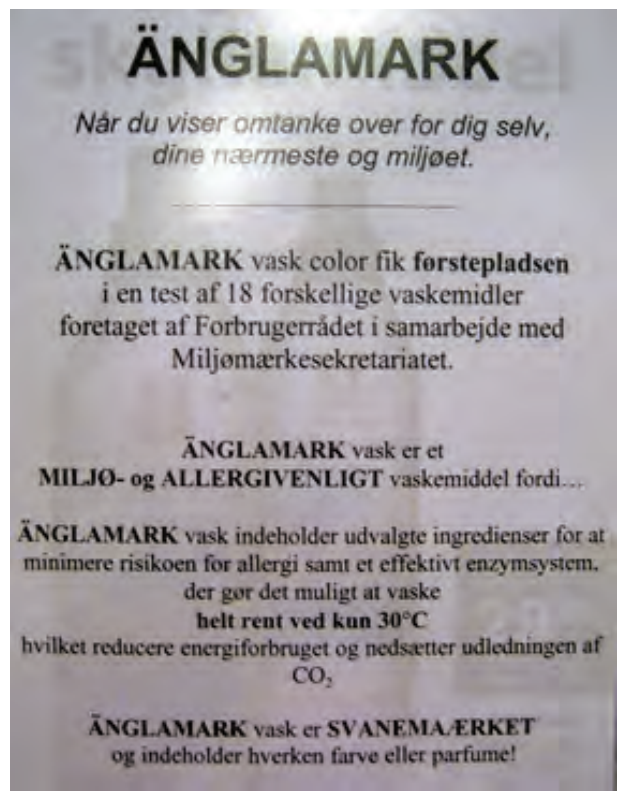

SuperBrugsen, Nørrebro i København, ligger i et område med mange miljøbevidste og vidende beboere. Derfor har man i butikken valgt at give endnu mere miljøinformation om produkterne, end hvad der er normal praksis i kceden. En yderligere begrundelse er, at der findes flere forskellige svane/blomstmcerkede vaskepulvere, og butiksbestyreren har derfor valgt at tydeliggøre de fordele, som han mener, at Coops Änglamark produkter har (Foto: Kirsten Schmidt).

Kunderne henter dog langt fra kun deres viden om det miljøtilpassede/etiske marked fra kæderne selv, men også fra medierne, interesseorganisationer, offentlige kampagner - og ikke mindst ,jungletelegrafen“.

Når først kunden er i butikken, har medarbejdernes viden betydning. Ekspedienterne skal være et skridt foran og kunne forklare kunderne om økologi, fairtrade, miljømærkning osv. Hvor omfattende og vigtig, dialogen mellem kunderne og ekspedienterne bliver vurderet til at være, varierer. Nogle dagligvarekæder vil gerne svare på kundernes spørgsmål, men ikke aktivt påvirke dem til at købe ét produkt frem for et andet. Andre dagligvarekæder tillægger medarbejdernes viden en større betydning og mener, at det er med til at tiltrække og fastholde kunderne, når man kan give dem gode svar.

I specialbutikkerne er dialogen relativt stor, og mange kunder har ofte en vis viden, inden de kommer. De ansatte skal kunne møde kunden, hvor hun er, og har derfor også brug for ret omfattende viden, hvis kunderne har det.

\footnotetext{
„Bästa sätt att främja försäljningen av ekologiska kläder är information til personalen och att denne sedan får kommunicera med kunderna og tala om att det er ekologisk bomull i. Det är som med alla andre typer av kläder att sälja via samtal och att visa upp produkten“.

Butikschef Rebecka Berg, Polarn o. Pyret
} 
Butikkerne følger også med i medierne for at være forberedt på emner, der dukker op.

\footnotetext{
„Omtale i medierne har stor betydning. Hvis der bliver sat fokus på et bestemt problem i en artikel, har det typisk en effekt i butikken i omkring to uger, hvor kunderne stiller spørgsmål. Hvis der kommer opfølgende artikler, holder effekten længere. Det er vigtigt at følge med i de emner, som medierne rejser. MATAS hovedsæde orienterer os derfor løbende om relevante nyheder i medier og ruster os til at svare på evt. spørgsmål herom fra kunder“.

Butiksbestyrer Carl-Erik Christensen, MATAS, Allerød.
}

Kædernes indsats for at uddanne og motivere de ansatte er behandlet i et senere afsnit.

Opbygning af kundernes vidensniveau er en langsigtet indsats, som skal fastholdes over mange år. Dette kan måske være med til at forklare, at detailhandelen i de forskellige lande holder fast i „det der kom først“ som det, der bliver gjort mest for at synliggøre. I Sverige slog de svanemærkede varer først igennem, og her er de tydeliggjort på hyldeforkanterne. I Danmark kom økologien først. Her er der skiltning for økologi på mange måder, herunder på hyldeforkanterne. Det er der ikke for de svanemærkede varer, som slog igennem senere. I dag er der så mange forskellige miljøtilpassede/etiske varer og mærker, at supermarkederne i Danmark vurderer, at det vil skabe forvirring, hvis alle de miljøtilpassede/etiske varer skal fremhæves specifikt - så forsvinder idéen med særlig skiltning. I det hele taget er man opmærksom på, at kunderne skal forholde sig til ganske meget information - ikke kun om miljø/etiske spørgsmål, så det er vigtigt at finde en god balance mellem tilstrækkelig information og for meget information.

Nogle kæder og virksomheder ser udvikling og profilering af egne, miljøtilpassede/etiske varemærker eller brugen af det overordnede virksomhedsbrand som „etisk garant“ som en måde at gøre valget lettere for forbrugerne, fordi man har indbygget mange forskellige hensyn under ét mærke. Det giver også en basal platform for den miljøtilpassede/etiske markedskommunikation. Omvendt kan der være en risiko for, at information og gode markedsargumenter ikke kommer i spil, hvis markedsføringen udelukkende fokuserer på varemærket. En af de interviewede butikker havde således valgt at supplere med ekstra information på udvalgte produkter af eget varemærke for netop at give mest mulig information til kunderne. 


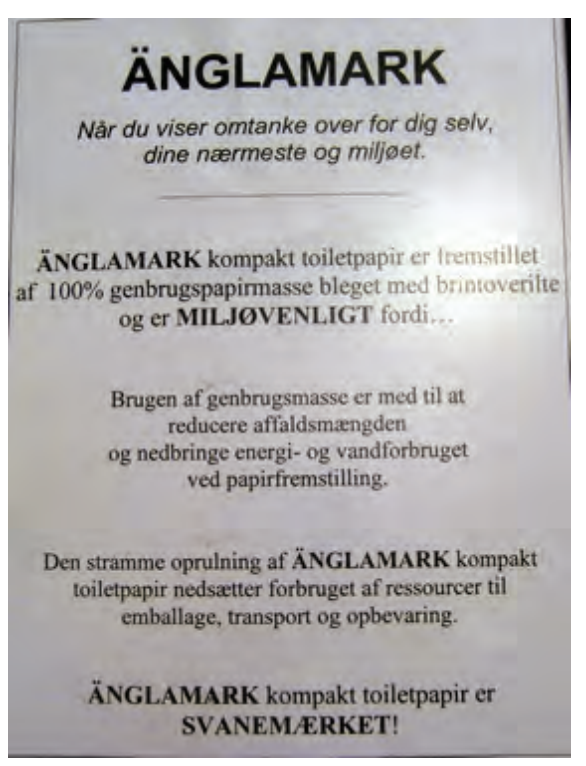

Dette skilt er fotograferet i SuperBrugsen, Nørrebro i København. Det har en tydelig placering ved den reol i butikken, hvor der findes husholdningspapir (Foto: Kirsten Schmidt).

Nogle kæder har valgt en meget direkte form for uddannelse af kunderne, hvor de afholder kurser, som også inddrager miljøhensyn. Byggmakker i Norge har i samarbejde med Grønn Hverdag afholdt kurser i 4 butikker for private om istandsættelse af boligen, og her indgik valget af miljøvenlige produkter. Kurset vakte stor interesse både i den lokale presse og $\mathrm{i}$ boligmagasiner. Desuden har Byggmakker købt et hus, som skal sættes fuldstændig i stand. Dette bliver filmet og brugt til at vise kunderne, hvordan man kan sætte i stand på miljøvenlig vis, både i forhold til valg af produkter og i forhold til håndtering af affald. Projektet er omtalt i Byggmakkers magasin „Forandring Fryder“ og på hjemmesiden.

Kilde: www.byggmakker.no.

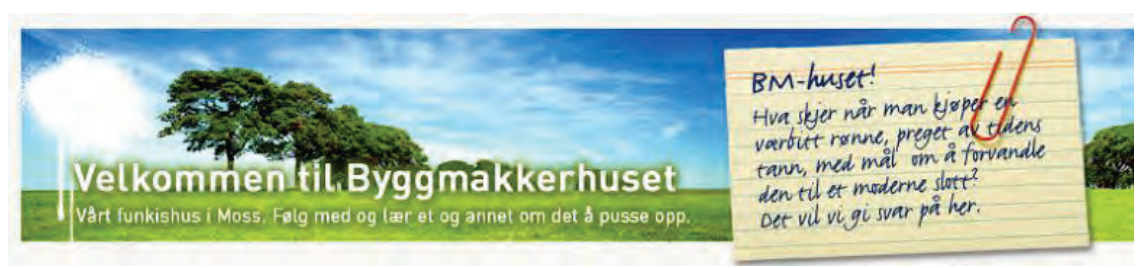

\subsection{Internt og eksternt samarbejde}

Dette afsnit fokuserer på:

- Samspillet internt i kæderne mellem det centrale niveau og butikkerne

- Samarbejdet med eksterne parter 


\section{Samspil mellem det centrale niveau og keedens butikker}

Generelt bliver politikker, strategier mm. udarbejdet centralt i kæderne, hvor det også besluttes hvilket basissortiment af miljøtilpassede/etiske varer, der skal være i butikkerne. Ejerskab, traditioner og holdninger er med til at bestemme, hvor udbredt den centrale styring er, og dermed hvor stort råderummet er for den enkelte butik. En del af markedskommunikationen styres centralt, herunder hjemmesiden og de reklameaviser, som dækker alle kædens butikker. Kæderne udarbejder også indretningsplaner for butikkerne, som tilpasser dem til de lokale forhold. I nogle kæder er ejerstrukturen ikke central, men baseret på privatejede butikker, og her er den centrale styring ikke så udtalt, og butikkerne har større frihedsgrader. Dette kan betyde, at de enkelte butikker har en højere eller en lavere miljø-/etisk profil end kæden generelt.

Indkøb og dermed udbuddet af miljøtilpassede/etiske varer styres i de fleste tilfælde ligeledes centralt via indkøbsafdelingerne, både egne varer (private labels) og andre mærker. I langt de fleste kæder skal butikkerne have et vist minimumssortiment, og desuden er der et større udvalg, som de frivilligt kan vælge til. I interviewene er der desuden set et tilfælde, hvor en butikschef har fået dispensation til at indkøbe yderligere varer, eftersom selv det udvidede sortiment i kæden ikke dækkede efterspørgslen i butikken. I nogle af de mere decentralt styrede kæder har butikkerne selv mulighed for at købe ind, så her kan sortimentet af miljøtilpassede/etiske varer være mere varierende.

I alle de interviewede kæder er der et samarbejde mellem markedsafdelingerne og de miljø/etisk ansvarlige, men der er forskel på, hvor tæt samarbejdet er, og hvad det omfatter. De miljø/etisk ansvarlige sikrer det faglige niveau i indsatsen, samt at markedsinformationerne er korrekte og ikke vildledende. Desuden følger de med i udviklingen på området bl.a. via dialog med eksterne parter og holder regelmæssige møder med markedsfolkene for at opdatere disse. I leader-kæderne er de markedsansvarlige selv meget interesserede i miljøområdet og er med til at drive udviklingen. I en af de interviewede kæder er den miljø/etisk ansvarlige samtidig ansvarlig for kædens overordnede kommunikation og PR, hvilket betyder, at afdelingen er direkte involveret i kædens strategi- og forretningsudvikling.

„MATAS har valgt organisatorisk at koble ansvaret for miljø og PR, fordi miljøog sundhedsområdet er vigtigt i forhold til både risk management og markedsudviklingen“.

Informations- og miljøchef Henrik E. Johannsen, MATAS hovedscede

De store supermarkedskoncerner har typisk flere kæder med selvstændige profiler. De(n) miljø/etisk ansvarlige er placeret på koncernniveau, mens markedsafdelingerne fungerer på kædeniveau, og det er dem, der har ansvaret for at udvikle kædens marked, så længe det foregår inden for koncernens overordnede strategier. Det er almindeligt inden for koncer- 
nerne både at have discountbaserede kæder og kæder med en stærk etisk profil. Det betyder, at den overordnede koncernpolitik typisk udstikker nogle overordnede rammer, som kæderne skal følge, men rammerne kan fyldes ud på forskellig vis og med forskellig vægtning af produktkategorierne. Nogle kæder er desuden selvstændige enheder, der er blevet købt op af koncernen, og her fortsætter man sin egen linje og har selvstændige politikker, indkøbsafdelinger mm.

Selv om en væsentlig del af indsatsen bliver styret centralt, har den enkelte butik betydning for omfanget af salget. Butikken spiller i sagens natur tæt sammen med kunderne, og den lokale efterspørgsel efter miljøtilpassede/etiske varer varierer. Butikkens størrelse og fysiske indretningsmuligheder har ligeledes indflydelse på, hvordan og i hvilket omfang det er muligt at prioritere de miljøtilpassede/etiske varer. Fx kan små butikker have begrænsede muligheder for at føre et stort sortiment, fordi det meste af butikken er fyldt op af de basisvarer, som man skal have inden for de forskellige miljøtilpassede/etiske såvel som konventionelle produktkategorier.

\footnotetext{
„Jeg forsøger at skabe ekstra plads til de økologiske varer i butikken, men vores problem er, at med $830 \mathrm{~m} 2$, så er det en lille butik. Hvis jeg havde dobbelt så meget plads, kunne jeg sælge væsentlig flere økologiske varer, for efterspørgslen er der. Derfor prøver vi hele tiden at se på, hvor der er mulighed for at gøre andre områder lidt mindre“.

Uddeler Micki Høyer Hansen, SuperBrugsen, Ndr.Frihavnsgade.
}

Derudover har den enkelte butikschefs holdning og prioritering stor betydning for den konkrete indsats i butikkerne og dermed for salget. Miljøildsjæle findes, og det kan bl.a. ses, når de flytter til en anden butik og tager et højere salg med sig. Ildsjælene baner vejen og skaber forretningsresultater - så følger de andre butikker med. Nogle af de interviewede butikschefer gør en indsats for de miljøtilpassede/etiske varer, fordi de har en personlig holdning til det, andre fordi de kan se at det er god forretning.

\footnotetext{
„Både jeg og kunderne synes at økologi og fairtrade er rigtig vigtigt, så jeg opfylder det behov, der er i lokalsamfundet. Men derudover synes jeg personligt, at det er vigtigt, så jeg handler også økologisk, hvis det er god kvalitet, men jeg er ikke øko-freak. Hvis varerne er meget dyre og ikke så gode som de konventionelle, så køber jeg dem ikke“.

Uddeler Micki Høyer Hansen, SuperBrugsen Ndr. Frihavnsgade
}
„Økologi er god forretning, salget går strygende, og derfor gør jeg en del ud af det - ikke fordi jeg er specielt idealistisk (...) For et år siden skulle vi bygge om i bu- tikken, og det var vigtigt for mig at blive klar på, hvad der skulle differentiere os fra de lokale konkurrenter. Vi er klart bedst på kød og grønt, men der måtte gerne være endnu mere, så vi prioriterede masser af plads til økologi“.
Varehuschef Morten Houmann, Kvickly, Vordingborg


Butikschefens indstilling og indsats slår igennem på flere måder i butikken. For det første hvordan de miljøtilpassede/etiske varer er placeret i butikken, og hvor stort sortimentet er. For det andet om butikken vælger at fremhæve miljøtilpassede/etiske varer på tilbudspladser, også når der ikke er kædebaserede kampagner. For det tredje via den måde, der bliver skiltet med de miljøtilpassede/etiske varer, og hvor omfattende information, der findes om varerne i butikken. For det fjerde ved at sørge for, at de miljøtilpassede/etiske varer er hjemme og på hylderne, dvs. ved at undgå tomme hylder. Og for det femte, hvordan han/hun motiverer personalet til at prioritere området. Den konkrete indsats i butikkerne er behandlet i afsnit 6.7.

Hvem er så drivkræfter i den miljø/etisk relaterede markedsudvikling? Interviewpersoner fra centralt hold mener, at det centrale niveau er den væsentligste drivkraft især i opbygningsfasen, fordi butikscheferne har øjnene rettet mod salgstallene, og fordi det kræver en koordineret indsats. Når markedet er modnet og efterspørgslen bliver mere synlig, stiger interessen hos butikkerne. Interviewpersoner fra butikkerne fremhæver, at de har en væsentlig betydning, fordi det er dem, der har kontakten med kunderne og samler op på, hvad kunderne ønsker. Begge parter har således en væsentlig rolle at spille i udviklingen af det miljøtilpassede/etiske marked, men pilen peger på det centrale niveau som igangsætter og butiksniveauet som det, der skaber markedet.

\section{Samarbejde med eksterne parter}

Det miljø/etisk relaterede område er meget informationstungt og komplekst, og derfor samarbejder detailhandelen gerne med eksterne parter. Dels for at få del i deres viden, og dels fordi forenede kræfter kan give større gennemslagskraft i offentligheden og dermed fremme forståelsen for området. Desuden er anerkendte NGO’er med til at skabe troværdighed om kædernes indsats.

Detailhandelen samarbejder med mange forskellige NGO'er og andre organisationer - fx UNICEF, Red Barnet, Folkekirkens Nødhjælp, Kræftens Bekæmpelse, Cancerfondet, WWF, Naturbeskyttelsesforeninger, miljømærkesekretariater, Fairtrade-organisationer, Regnskogsfondet, økologiske foreninger, forbrugerorganisationer, osv. Nogle samarbejdsrelationer er projektbaserede, $\mathrm{fx}$ om en konkret kampagne, mens andre er mere langvarige og handler om fx uddannelse, opbygning af viden, produktudvikling og markedsudvikling.

Detailhandelen er dermed et godt træfpunkt for mange forskellige organisationer. Organisationerne kan opnå synlighed for deres mærkesager, og detailhandelen kan få større viden og input til deres indsats. 


\subsection{Medarbejderne - uddannelse og motivation}

De interviewede giver udtryk for, at de ansattes viden spiller en rolle, og at de skal være i stand til at svare på spørgsmål fra kunderne. Derfor modtager butikkerne også løbende information fra de centrale niveauer, fx bruges intranettet en del. Helt basalt skal de ansatte vide, hvad de forskellige mærkningsordninger står for, dvs. fakta om økologi, fairtrade, miljømærkning, FSC, MSC, naturkosmetik osv. Og så skal de vide, hvem der kan svare, hvis de ikke selv kan. Behovet for denne type information er størst i starten, når et nyt mærke eller en ny produktserie bliver introduceret. Fordelene ved, at de ansatte kan give gode svar, har flere facetter. Dels handler det om at give god service i butikken, hvilket i sig selv kan bidrage til at fastholde kunderne. Dels er det en forretningsmæssig nødvendighed at kunne forklare en kunde, hvorfor fx en økologisk variant er dyrere end den konventionelle. Og dels er det et spørgsmål om de ansattes egen motivation - det er mere meningsfuldt at gøre en indsats, når man forstår baggrunden for den. Men uanset om man selv „tror på sagen“, skal de kunder, der synes, at det er vigtigt, opleve at blive taget seriøst.

Ud over at informere - via intranettet, besøg i butikkerne, andet informationsmateriale - holder flere kæder kurser for de ansatte. Disse kurser kan være meget forskellige i form, indhold og omfang, lige som nogle er obligatoriske og andre er frivillige. Netbaserede kurser vinder frem, fordi de ansatte kan tage kurset på distance, og når der er tid til det. Desuden er det langt hurtigere og billigere, end hvis der holdes mere traditionelle klassekurser. De netbaserede kurser kan endvidere i princippet følges af alle de butiksansatte, uanset om de har en butiksuddannelse bag sig, eller om de er ansat som medhjælpere i en kortere eller længere periode. Netop den store udskiftning i personalet bliver set som en væsentlig barriere for opbygning af et højt vidensniveau hos de ansatte.

Kurserne - uanset form - kan handle om alt fra:

- grundlæggende kemisk forståelse og påvirkning af mennesker og miljø,

- generelle begreber som økologi eller fairtrade,

- specielle problemstillinger fx i tilknytning til allergi,

- kendskab til en bestemt produktserie, herunder de sundheds- og miljømæssige aspekter,

- og til en mere forretningsrelateret vinkel om, hvordan man fremmer de miljøtilpassede/etiske produkter i butikkerne og påvirker kollegerne til at gøre en indsats.

Ofte er det ansatte fra kædens centrale niveau, der holder kurserne, andre gange er det leverandørerne/producenterne, som kommer og fortæller om deres produkter, og atter andre gange er det eksterne konsulenter eller 
organisationer, der står for undervisningen. Selv om de interviewede giver udtryk for, at de ansattes viden og indstilling er vigtig, skinner det også igennem, at det er et område med plads til forbedringer i form af en mere omfattende og mere systematisk indsats.

Anonyme besøg i detailhandelen viser, at mange ansatte stadig har svært ved at kende de forskellige mærker fra hinanden og endnu flere kan ikke fortælle mere specifikt, hvad et konkret miljø/etisk mærke handler om. Hvis der foregår en træning af de ansatte, omfatter det normalt kun det fastansatte personale, og ikke løstansatte ungarbejdere mm., som der kan være en del af i butikkerne i eftermiddags- og aftentimerne.

Egentlig uddannelse og træning af personalet er én ting, noget andet er at fremme de ansattes motivation til at gøre en indsats for de miljøtilpassede/etiske produkter, og her bruger kæderne flere tiltag, hvor nogle styres fra centralt niveau, mens andre er lokale i den enkelte butik.

Konkurrencer mellem butikkerne i en kæde om at have det største salg af en eller flere udvalgte, miljøtilpassede/etiske produktgrupper er et eksempel på et centralt initiativ. Butikkerne giver på deres side udtryk for, at de synes, at det er sjovt og motiverende - og så giver det en mulighed for at lære af hinanden, fx ved at besøge den butik, der har klaret sig bedst.

I forhold til at opbygge de ansattes viden og motivation lokalt er diskussioner kollegerne imellem vigtige. Hvis en af de ansatte er ekstra interesseret, smitter det af på de andre. Også de mere formaliserede diskussioner på møder spiller en rolle - at sætte økologi, sundhed, miljømærkning eller andet på dagsordenen fremmer synligheden og gør de ansatte mere opmærksomme på emnet. I forhold til at påvirke salget er det værd at nævne et par eksempler:

\footnotetext{
„Hver uge holder vi et planlægningsmøde, hvor vi aftaler, hvad der skal ske i forhold til de næste to ugers tilbud. Jeg søger at påvirke mine ansatte til at prioritere økologi og Änglamark, og det gør de også gerne, for de kan jo mærke, at kunderne efterspørger det. Vi koordinerer på tværs af afdelingerne, så vi får samlet fokus. Hvis flere afdelinger i samme uge gør noget for en varegruppe, bliver det meget synligt i butikken. Det betyder, at der godt kan være en udstilling i en afdeling, hvor varerne egentlig hører mere hjemme i en anden afdeling. Koordineringen er også med til at skabe korpsånd og fælles prioritering i personalegruppen“. Uddeler Micki Høyer Hansen, SuperBrugsen, Ndr. Frihavnsgade.
}

„Vi får information från Polarn o. Pyrets kvalitetsavdelning om olika märkninger osv. Sedan pratar man mycket om dessa frågor bland personalen - kanske er vi ekstra interesserade för det att en av de anställda er engagerad i miljöfrågorna“. Butikschef Rebecka Berg, Polarn o. Pyret.

I MATAS, Silkeborg i Danmark skulle en elev gennemføre en praktisk prøve af en uges varighed i butikken. Hun valgte at sætte fokus på de svanemærkede produkter, og en af aktiviteterne bestod i at starte med et morgenmøde med kollegerne, hvor de i fællesskab fandt frem til alle fordelene for kunderne. Det blev skrevet på en planche, som hang i frokoststuen ugen ud. Ud over at det øgede fokus gav et stort salg, har der været en langsigtet effekt i og med, at de ansatte er blevet 
bedre til at tolke kundernes signaler og dermed hurtigere fanger, hvis nogen er interesserede i sundhed og miljø.

Kilder: Materialist Mona Holm Sørensen, MATAS, Silkeborg samt Materialisten, nr.1, 2008,

\subsection{Den aktive markedskommunikation}

Dette afsnit behandler følgende emner:

- Budskaber og slogans

- Tilbudsaviser og andre medier

- Mærker og anden information på produkterne

- Kampagner

\subsubsection{Budskaber og slogans}

Fakta, holdninger, oplevelser og gode historier - og masser af det - synes at være væsentlige ingredienser i markedskommunikationen om de miljøtilpassede/etiske varer. Ud over behovet for masser af information er det ud fra denne undersøgelse ikke muligt at konkludere entydigt på, hvad der bruges hvornår, men der synes at være nogle tendenser.

Når det handler om at slå kendskabet til et mærke og/eller en mærkningsordning fast, er der behov for fakta og god dokumentation, for troværdigheden er vigtig. Men fakta alene er sjældent nok til at ændre forbrugernes adfærd, så derfor er der også brug for gode historier og oplevelser. Dette bruges inden for økologi og fairtrade, men er tilsyneladende ikke så udbredt, når det drejer sig om de svane- eller blomstmærkede varer. Oplevelser kan fx være besøg på økologiske landbrug, mens gode historier er centrale i forbindelse med fairtrade. I begge tilfælde handler det om at knytte forbindelser „fra jord til bord“ mellem bønderne - lokale eller i 3. verdenslande - og forbrugerne. I fairtrade markedsføring bruges ofte billeder (bønder, børn) for at personificere kundernes forhold til produkterne. Kvalitet og god smag er også helt centrale: „Man behøver ikke at være idealist, bare gå efter den gode smag og kvalitet“ er derfor også et anvendt budskab.

Inden for de svane-/blomstmærkede varer handler budskabet i høj grad om sundhed og om at beskytte børnene, både ens egne og de kommende generationer. Rene miljøargumenter bliver ikke brugt i sig selv, men bliver kombineret med andre argumenter, som forbrugerne ifølge detailhandelen bedre kan forholde sig til. Her kommer hensynet til egen og sine nærmestes sundhed i første række. Klimadebatten i disse år har fået flere forbrugere til også at tænke på mere overordnede miljøhensyn, lige som mediefokus på enkelte, skadelige stoffer som parabener, parfumer og andre tilsætningsstoffer kan mærkes i butikkerne. Positive bud- 
skaber, der handler om tilvalg er bedre end negative budskaber, der handler om fravalg. Den løftede pegefinger duer ikke.

Brugen af slogans og særlige, holdningsbaserede budskaber er udbredt i tilknytning til kampagner, både mere kortvarige kampagner, som er rettet mod udvalgte produkter, og mere langvarige, holdningsbaserede kampagner. Slogans er især fundet i tilknytning til økologi - her er nogle eksempler:

- $\quad$ ICA - I love Eco (ICA, Sverige)

- Jorden kalder (Kvickly, Danmark)

- Alle skal ha’ råd til økologi (Netto, Danmark)

- Naturlig mat (flere kæder i Norge)

- En helt naturlig del af livet (Änglamark, Coop Danmark)

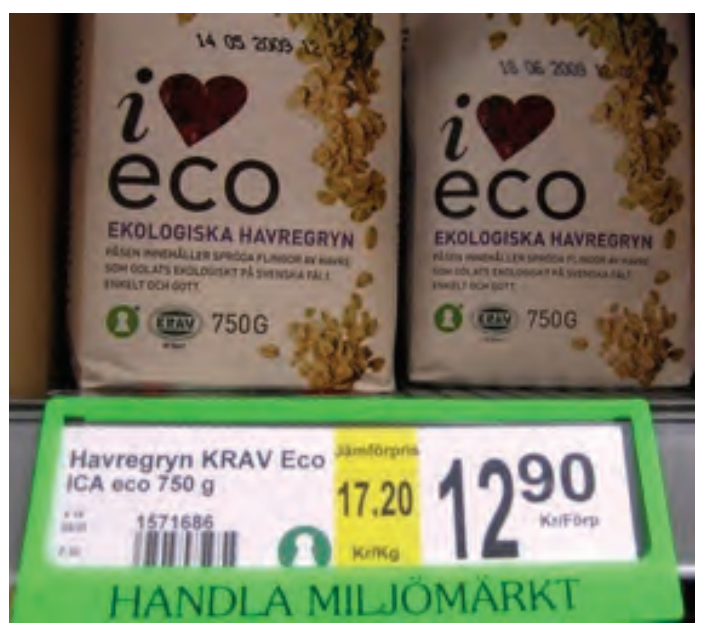

ICA's slogan er nu blevet omdannet fra at være et kampagneslogan til at være navnet på deres økologiske private label varemcerke, som blev lanceret i starten af 2008. Disse økologiske havregryn er fra ICA, Torsås i Sverige (Foto: Kirsten Schmidt).

Ellers synes leaders i detailhandelen mere at satse på at integrere miljøindsatsen i den overordnede forretning mere end at profilere den som et separat fokusområde.

Emballagen og mærkerne på emballagen sender signaler, som kæderne også er bevidste om. Specielt inden for private labels og/eller eget design gør detailhandelen en indsats for at emballagen og budskaberne på denne skal sende de rette signaler. De skal opleves som pæne eller på anden måde attraktive, så forbrugerne dels bliver tiltrukket, og dels har lyst til at vise dem frem. Der er dog også et dilemma omkring emballage, idet nogle forbrugere helst ser, at emballagemængden minimeres eller helt kan undgås. Nogle detailhandlere tilbyder at tage brugt emballage fra egne varer retur. 


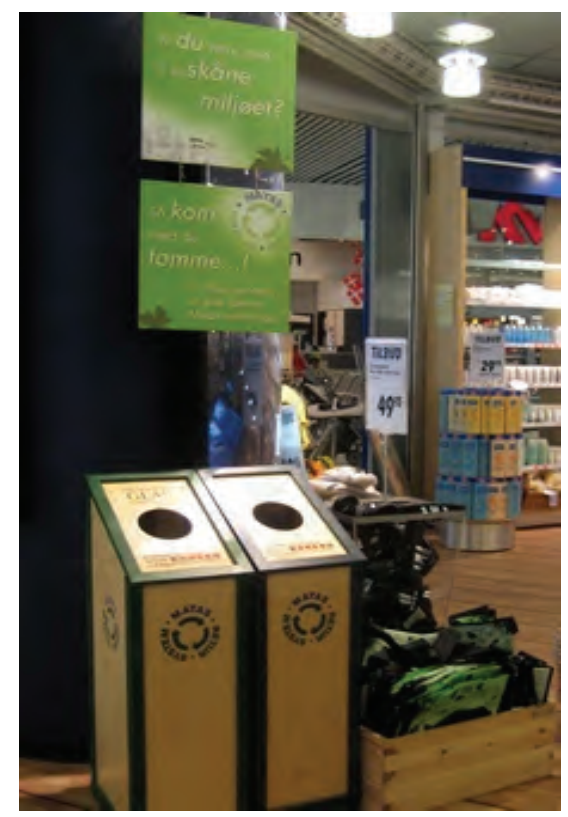

MATAS-kcedens butikker i Danmark tager tom emballage fra alle varer købt i MATAS retur for at fremme genbruget.I denne butik i Bruuns Galleri, Arhus, står beholderne til den tomme emballage lige ved indgangen. Ved siden af ses en kasse med slidstcerke indkøbsbcreposer, som kan bruges flere gange, og som Matas opfordrer kunderne til at købe i stedet for engangsbcreposer $i$ plast (Foto: Kirsten Schmidt)

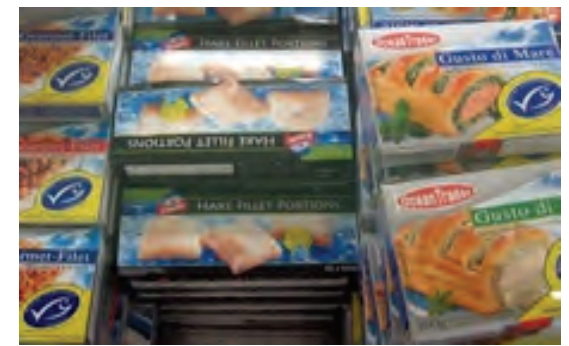

På det „nye” område-MSC-mærket har producenterne valgt en tydelig merkning på emballagen fra starten. Her foto fra et dansk discountsupermarked. (Foto: Kirsten Schmidt)

Efterhånden som de forskellige mærker (svanen, øko-mærkerne, fairtrade osv.) er blevet mere udbredte, dvs. findes på stadig flere produkter, er mærkerne også blevet mere synlige. Desuden er der sket en udvikling fra, at miljølogoet var lille og fandtes på bagsiden, til at det nu er på forsiden af emballagen, samt at det er blevet større.

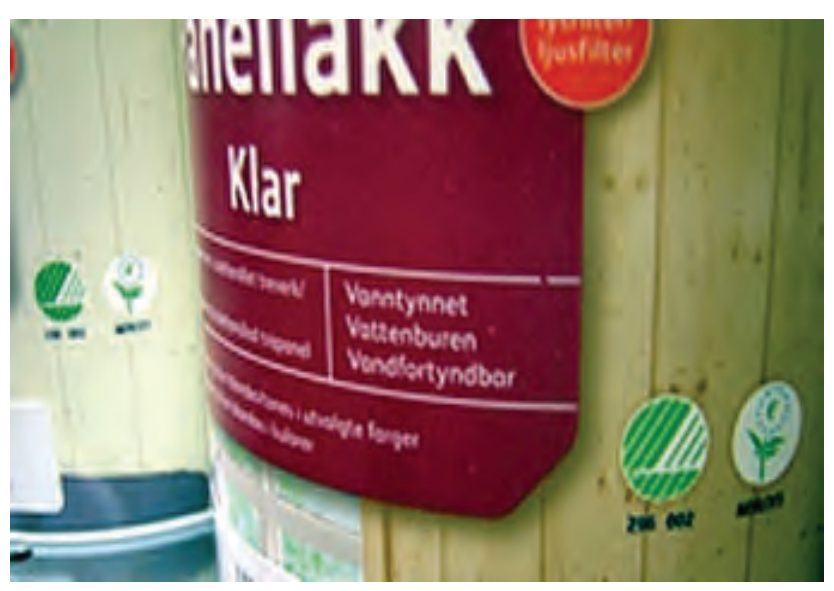

Tydelig miljømæerkning på produkterne i Byggmakker, Norge. (Foto: Hanne Møller) 


\subsubsection{Tilbudsaviser og andre medier}

De periodiske tilbudsaviser er det vigtigste markedsføringsmedie for detailhandelen - også når det gælder de miljøtilpassede/etiske varer. Der er dog visse begrænsninger og forskelle i, hvordan der bliver kommunikeret via dette medie. Tilbudsaviserne, som er mest udbredte i Danmark, dækker store, regionale områder (i Danmark hele landet), derfor kan der kun omtales produkter, som findes i alle butikker, dvs. det grundlæggende basissortiment, ikke det større specialsortiment, som appellerer til det grønne segment. Dog har de lokale ICA-butikker i Sverige på grund af ejerstrukturen mulighed for at udarbejde deres egne tilbudsaviser.

Tilbudsaviserne handler først og fremmest om pristilbud, og er derfor mest egnet til det blå segment. Tilbudsaviserne bruges dog også til at introducere nyheder og sætte fokus på udvalgte produktgrupper, og i denne sammenhæng er de miljøtilpassede/etiske produkter også i spil. I tilbudsaviserne drejer kommunikationen om de konventionelle varer sig om pris, mens kommunikationen om de miljøtilpassede/etiske varer mere handler om information og profilering. I Sverige og Norge er andre reklameformer mere udbredte, fx direct mails for økologiske produkter, fokuserede annoncer i lokalaviser og i magasiner rettet mod kvinder og børnefamilier, samt TV-reklamer og lignende.

Når man sammenligner markedsføring af miljøtilpassede/etiske varer og konventionelle varer, er der således ikke så stor forskel på valget af medier, men mere på typen af information og budskaber. Markedsføringen af miljøtilpassede/etiske produkter handler om holdninger og indeholder information om fx et mærke - dvs. at der ikke kun er fokus på pris og produktbeskrivelser.

Som et særligt „medie“ kan dog nævnes, at flere blandt leaders nævner, at de holder oplæg til konferencer og andet, hvor formålet er at profilere kædens indsats og holdninger, men samtidig er der også mulighed for at nævne særlige produktgrupper, typisk private labels.

Alle kæderne bruger deres hjemmesider til at fortælle om deres holdninger og indsats på det miljømæssige/etiske område, men der er forskel på omfang, detaljeringsgrad og typen af information. Nogle vælger at fokusere på holdninger og beskrivelser af indsatsen, mens andre vælger at fokusere på mere produktrettet information og handlinger ud fra det synspunkt, at kunderne ønsker at vide, hvad butikkerne reelt gør - snarere end hvorfor de gør det.

„På MATAS’ hjemmeside er der stillet fokus på, hvad MATAS konkret gør på området, snarere end hvorfor vi gør det. Vi vælger at udvise ansvarlighed igennem konkret handling frem for at trætte forbrugerne med en masse ideologiske slagord og hensigtserklæringer“.

Informations- og miljøchef Henrik E. Johansen, MATAS. 
Den mere holdningsbaserede information på hjemmesiderne er ikke nødvendigvis salgsrettet, men kan i mindst lige så stort omfang have en intern funktion i koncernen/kæden, nemlig at vise de ansatte og andre interesserede at kæden har en holdning til miljøområdet. Nogle koncerner er meget bevidste om at motivere de ansatte på det centrale niveau til at tænke miljø og etik med i deres arbejde.

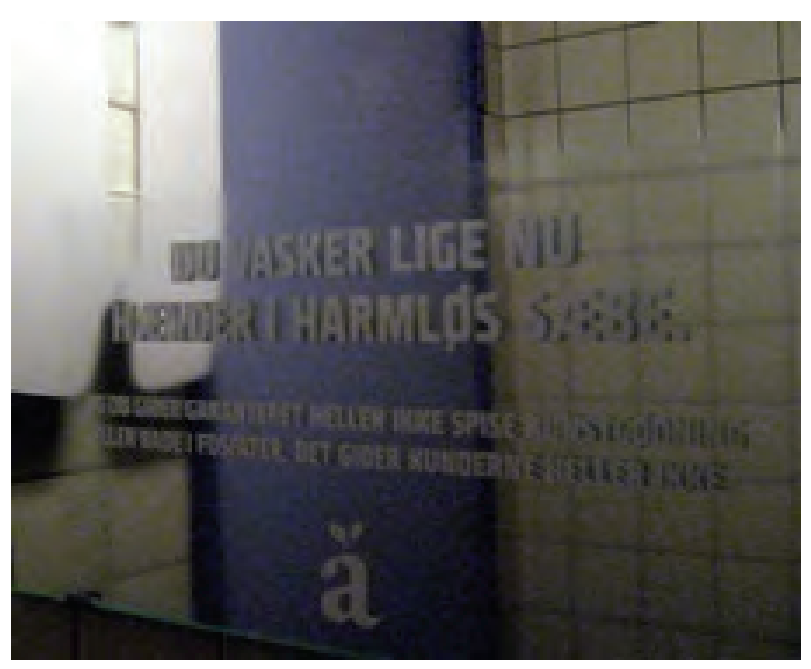

Set på toilet i Coop Danmarks hovedkontor. Teksten på spejlet lyder: „Du vasker lige nu hæender i harmløs scebe. Og du gider garanteret heller ikke spise kunstgødning eller bade i fosfater. Det gider kunderne heller ikke"(Foto: Kirsten Schmidt).

Langt de fleste af de interviewede kæder har valgt at bruge indsatsen aktivt i markedsføringen, og de miljøtilpassede/etiske produkter indgår i kædernes almindelige markedsføringsmateriale sammen med de konventionelle produkter. Der er dog forskel på, hvor højt de miljøtilpassede/etiske bliver prioriteret, idet nogle vælger at give de miljøtilpassede/etiske varer mere plads i reklamerne end den faktiske andel af omsætningen berettiger til. Det ses som en investering, som man forventer tjener sig hjem.

\subsubsection{Mcerker og anden information på produkterne}

Mærkerne er en god kommunikationsplatform, fordi de visuelt er let genkendelige og dermed gør det lettere at finde de miljøtilpassede/etiske varer i butikkerne. Mærkernes succes handler især om to aspekter, som hver især er væsentlige: troværdighed og kendskab. Et tredje aspekt er mærkernes udbredelse, altså hvor mange mærkede produkter, der findes på markedet, men det er ikke med i denne undersøgelse. Dog bør det nævnes, at svanemærket på nogle produktområder er blevet så udbredt, at stort set alle produkter er mærkede, og dermed kan kunderne ikke undgå at vælge de mærkede produkter. 


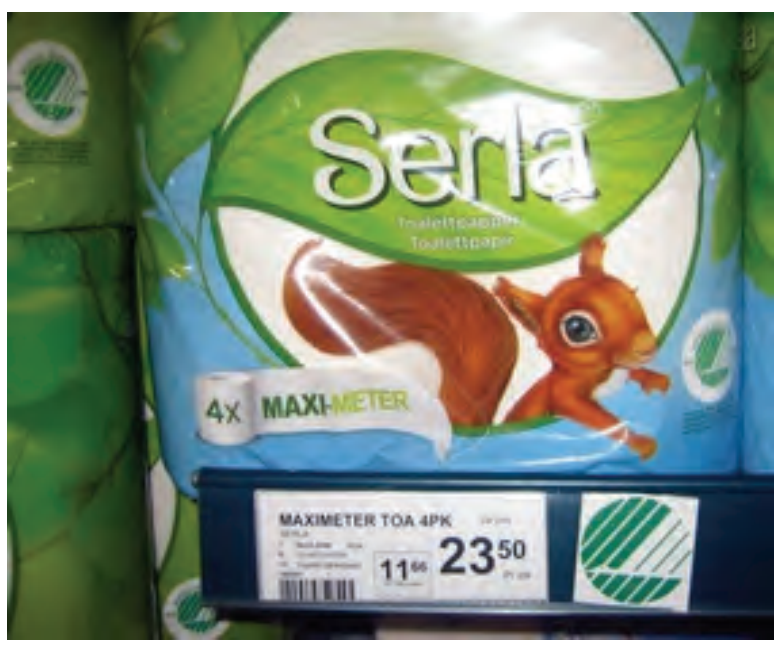

„,Alle‘ kjøber svanemœrkede mykpapir og vaskemiddel, fordi at sortimentet i hovedsak består af disse - på noen produktgrupper utgjør sortimentet opp mot $100 \%$. Dette synes jeg er godt, på denne måden bliver alle forbrukere litt mer miljøvennlige gennem sin daglige handel “ Miljøchef Knut Lutnces, Coop Norge (Foto: Hanne Møller).

Man kan dog også bemærke, at hvis stort set alle produkter i en produktgruppe er svanemærket, så synes en af ambitionerne med mærket - at det kun skal kunne opnås af de omkring 30 \% bedste på markedet i en given produktgruppe - ikke at være opfyldt.

For detailhandelen er mærkerne med til at signalere troværdighed, og det er vigtigt, hvis kunderne skal overbevises om og fastholdes i at vælge de miljøtilpassede/etiske produkter. Omvendt er der en vis skepsis over for mærker og andre statements, som ikke er godkendt af en uafhængig tredjepart. Selv i forhold til de anerkendte mærker bliver der udtrykt skepsis i forhold til, om de nu er gode nok - dette er fx tilfældet i Norge, hvor der er en udbredt skepsis over for FSC-mærket.

De kæder, som har egne varemærker, går meget op i at stille krav til leverandørerne og sikre dokumentation, for her står de selv inde for produkterne. Derimod synes processen at være mindre omfattende i forhold til mærker fra andre brands. Her er holdningen mere, at hvis produktet er svanemærket, økologimærket eller lignende, så er det godt nok.

Nogle kunder ved ganske meget og fungerer som vagthund i forhold til troværdigheden. De er med til at gøre butikkerne opmærksomme på, at der kan være problemer eller brådne kar. Dette samspil indgår i det værdifællesskab, som leaders opbygger med deres kunder.

Ud over selve produktmærkerne er andre mærker eller logoer i spil, typisk hvis en kæde samarbejder med en organisation om en sag. Her bruges organisationens logo i markedsføringen som en yderligere garanti for troværdigheden. En af de interviewede kæder - MATAS i Danmark anvender desuden farvekodning til at signalere ét bestemt aspekt nemlig indholdet af parfume i produkterne. Disse farvekoder går på tværs af miljømærket, idet der findes såvel parfumerede som uparfumerede varianter inden for både svanemærkede og ikke svanemærkede produkter. 
Farvekodningen blev indført for at hjælpe de forbrugere, der har særligt fokus på parfumestoffer.

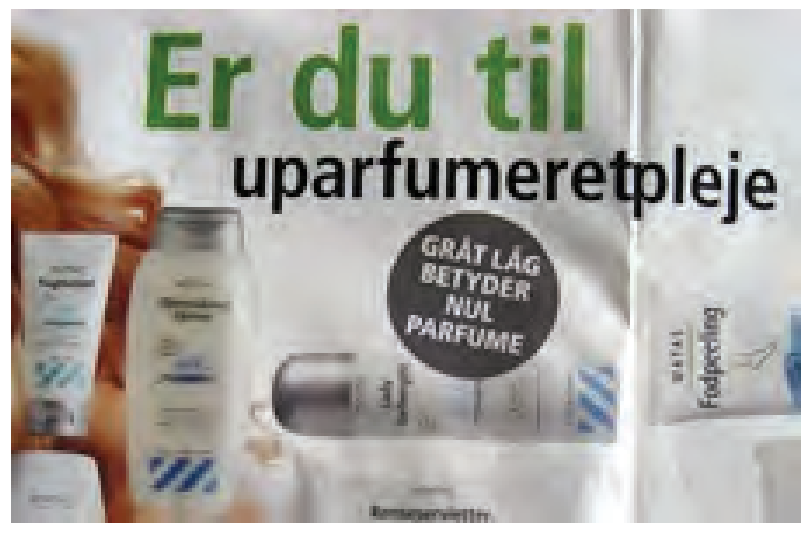

Foto fra MATAS, Danmarks, husstandsomdelte tilbudsavis, september 2008 (Foto: Kirsten Schmidt).

Som denne undersøgelse også viser, er der flere miljø/etisk relaterede mærker på markedet. Nogle detailhandlere peger på, at det som forbruger kan være svært at forholde sig til de forskellige mærker og forstå, hvad de hver især dækker og ikke dækker. Ønskedrømmen for dem er derfor et holistisk mærke, som omfatter alle de relevante miljøaspekter. De arbejder derfor på at gøre deres eget logo/brand eller et bestemt private label til et sådant holistisk mærke, så forbrugerne ikke behøver at forholde sig til mange forskellige, men „nøjes“ med det ene. Formålet er at gøre det lettere for forbrugerne, men detailhandelen er også meget opmærksom på, at det lægger et endnu større ansvar på dem selv. Andre kæder vælger at gøre en særlig indsats for at hjælpe kunderne gennem „mærkejunglen“ se afsnit 6.7.

Kendskabet til mærkerne opbygges over lang tid, og når de først er slået igennem forsvinder de ikke igen, men der kan godt over tid ske en ændring i hvilke aspekter og særligt problematiske stoffer, der i offentligheden bliver lagt vægt på. Her står mærkerne som en overordnet garanti for ,det gode“, selv om man som enkeltperson ikke nødvendigvis har styr på detaljerne bag.

Netop tidsaspektet, at det tager lang tid at opnå en høj kendskabsgrad, kan blive en udfordring for detailhandelen på det økologiske område. De nationale, nordiske økologimærker er efterhånden blevet meget kendte, men der er i EU truffet beslutning om et fælles EU økologimærke. Dette findes allerede på nogle produkter og skal på sigt erstatte de nationale mærker, og heri ligger der en stor udfordring i forhold til at opbygge såvel kendskab som tillid og troværdighed hos forbrugerne. 


\subsubsection{Kampagner}

„Kampagner“ dækker over flere forskellige situationer og kan have forskellige formål og set-up. Butikkerne bruger begrebet om de aktiviteter, de gennemfører i en afgrænset periode, hvor der er særlig fokus på et bestemt produkt eller en varegruppe. Disse aktiviteter er beskrevet $i$ afsnit 6.7 om indsatsen i butikkerne.

Kampagner dækker også over et mere omfattende projekt med planlagte aktiviteter, som er afgrænset i tid, og hvor fokus er bredere end at sælge „et godt tilbud“. Det kan være i den enkelte kæde, eller det kan være forankret i en organisation, som samarbejder med flere kæder om at opfylde formålet med den pågældende kampagne. Dette afsnit handler om kampagner i den sidste betydning.

\section{Formål med kampagnerne:}

Kæderne gennemfører kampagner eller deltager i eksternt organiserede kampagner ud fra forskellige formål. Først og fremmest er kampagner et middel til at opbygge kædens brand og fremme kendskabet til egne varemærker og andre væsentlige produktgrupper. I forhold til miljø/etik området handler det i høj grad om at profilere, at kæden har en holdning og gør en indsats, men derudover handler det også om at opbygge kendskabet til de forskellige ordninger (økologi, fairtrade, svanemærket,...). Den miljøtilpassede/etiske indsats generelt favner desuden mange komplekse forhold, som det er svært at kommunikere om i en sammenhæng. I kampagner kan man fokusere på et enkelt eller få udvalgte aspekter, men erfaringerne er, at det kun er troværdigt at fremhæve enkelt-aspekter, hvis der også er styr på helheden.

Kampagner, der fokuserer på at opbygge kendskab til en bestemt ordning, bliver oftest organiseret af organisationerne bag ordningen, mens detailhandelens rolle primært er at sørge for, at de produkter, der bliver stillet skarpt på, findes og bliver gjort synlige i butikkerne. I disse kampagner, som har et relativt langsigtet perspektiv, samarbejder detailhandelskæderne også indbyrdes, fordi alle har fordel af, at kendskabet til den pågældende mærkningsordning stiger. I Danmark er der opbygget en tradition, hvor forskellige organisationer holder faste kampagneuger hvert år. Fx er uge 9 fairtrade, uge 35 er økologi og uge 41 er svane/ blomstmærket. Den faste rytme er godt for detailhandelen, fordi det gør det lettere at indarbejde disse kampagner i deres langsigtede planlægning, indkøb, markedsføring osv.

Formålet med kædernes egne miljø-/etisk relaterede kampagner er ofte mere direkte rettet mod en umiddelbar forøgelse af salget af en given produkttype - samtidig med at kæden bliver (endnu mere) kendt for at forhandle disse produkter. Der kan også godt være langtidseffekter af kædernes egne kampagner, idet nogle kunder fortsætter med at købe de 
produkter, som kampagnen fokuserede på. De produktspecifikke kampagner handler ofte om at introducere nye produkter, eller få nye kundegrupper til at prøve miljøtilpassede/etiske varianter af en produktgruppe. Selvfølgelig må de kunder, der plejer at købe produkterne, også gerne benytte sig at kampagnetilbuddet, men det er ikke for deres skyld, kampagnerne bliver gennemført. Generelle rabatter - fx $20 \%$ rabat på alle varerne i det udvalgte sortiment - er et godt middel, når det handler om miljø-/etisk set små og dermed mindre kendte varegrupper, fordi kunderne her kan vælge at prøve netop de produkter af, som de selv har mest lyst til. Miljøtilpassede/etiske varegrupper med stort salg er det ikke så nødvendigt at køre kampagner på; de sælger sig selv.

Selv om kampagner er rettet mod forbrugerne, sender de også vigtige signaler til producenterne om, at detailhandelen ønsker at sælge disse varer, og at varerne bliver solgt. Fx var Coop Sveriges første kampagne et opråb, hvor Coop opfordrede producenter, som ikke brugte kemikalier eller som arbejdede med dyrevelfærd, om at henvende sig, for man ville gerne sælge deres produkter.

\section{Kendetegn ved gode kampagner:}

Succesrige kampagner er først og fremmest dem, der giver et større salg. Det er selve formålet med en kampagne. Men det er også godt at give kunderne en god oplevelse ved at prøve noget nyt, gerne miljøtilpassede/etiske varer, så de fortæller andre om dem, og dermed bliver en form for ambassadører for butikken.

De bedste kampagner bygger på det positive tilvalg frem for negativt fravalg. Desuden skal der være et enkelt, klart budskab og en modtagelig målgruppe - og varerne skal findes i butikkerne! Jo mere produktspecifikke kampagner, jo større direkte effekt på salget. Mere brede kampagner er til gengæld gode til at opbygge den generelle bevidsthed og til at skabe profil.

Set over tid kan kampagnerne ikke stå alene. Det er vigtigt at vise, at der er grundlæggende holdninger og handlinger bag - der skal også være miljøtilpassede/etiske produkter på hylderne mellem kampagnerne, hvis kæderne ønsker kundernes tillid på området.

Andre kendetegn for succesrige kampagner er timing og involvering af kunderne. De kampagner, der ligger i tilslutning til helligdage (jul, påske mm.) og andre sæsonrelaterede begivenheder, giver størst positiv forskel i salget. Kampagner, hvor kunderne via deres køb bidrager til en særligt formål, har også stor gennemslagskraft. Denne type „etisk salg“ synes generelt at være stigende og er en måde at samle penge ind til forskning, bistand til udviklingsprojekter, støtte til udsatte grupper osv. 


\section{Effekten af kampagner:}

Kampagner for miljøtilpassede/etiske produkter giver positiv respons fra kunderne, som bliver glade for at finde ud af, at sortimentet er større end de troede. Kunderne får øjnene op for de miljøtilpassede/etiske produkter, og det bliver mere naturligt for dem at handle etisk efter en kampagne, men det er vigtigt at holde fast i en vedvarende indsats. Det er også vigtigt, at de butiksansatte er i stand til at informere kunderne og bidrage med viden, for når en kampagne sætter fokus på et emne, er der flere kunder, som stiller spørgsmål.

De interviewede kæder har forskellige erfaringer med, hvor stor effekt kampagner har på salget. Nogle mener, det er begrænset, og at kampagnerne mest har en informationseffekt. Andre giver udtryk for, at der er en stor salgsmæssig effekt, størst i starten, hvorefter det flader ud. Ved at køre kampagner med jævne mellemrum bliver interessen holdt ved lige og salget af de miljøtilpassede/etiske produkter bliver over tid løftet op på et højere niveau. Den måde, pristilbuddet i kampagnerne er sat sammen, synes at have en effekt på salget, idet generelle \%-rabatter eller „køb 3 og betal for 2" rabatter inden for et større sortiment af fx svanemærkede varer giver højere mersalg end pristilbud på udvalgte enkeltvarer.

\footnotetext{
„Vi gennemfører ofte kampagner, som kan være mere eller mindre omfattende. Det er især vigtigt for at skabe synlighed omkring de salgsmæssigt små varegrupper. I kampagnerne for de mindre varegrupper bruger vi fx generelle \%-rabatter frem for tilbud på enkeltvarer. Så kan forbrugerne prøve de varer af, som de kunne tænke sig, til en rigtig god pris“.

Marketingchef Tine Guldborg Bredvig, SuperBrugsen.
}

„Kampagnene gir en viss salgsøkning, men det er ikke særlig større enn ellers, så det er mest en informasjonseffekt“.

Kategoriansvarlig Kenneth Lindland, Meny-Ultra.

Blandt andre erfaringer fra butikkerne kan nævnes, at kendskabskampagner ikke skaffer flere kunder i butikken, men dem, der kommer, køber flere af de pågældende produkter. Endvidere har kampagnernes omfang betydning. Store landsdækkende kampagner, hvor der både er TVreklame, husstandsomdelt reklame og reklame i butikkerne, har større gennemslagskraft end mindre, lokale kampagner.

\subsection{Indsatsen i butikken}

Indsatsen i butikkerne handler om, hvordan de miljøtilpassede/etiske varer bliver placeret samt gjort synlige og attraktive for kunderne. Der er tale om en blanding af en dynamisk, vekslende indsats og en mere langvarig. Den vekslende indsats foregår primært i form af profileringskampagner og kampagner i samspil med de tilbudsaviser, som kædernes centrale niveau sender ud. Der kan også være tale om andre kampagner, fx 
samarbejde med en organisation om et bestemt emne, eller en lokal kampagne, hvor butikken selv vælger at sætte fokus på udvalgte produkter. Den mere permanente indsats er det stabile underlag, som også er der mellem kampagnerne. I de efterfølgende afsnit er beskrevet de virkemidler, som butikkerne anvender:

- Sortiment

- Placering i butikken

- Skiltning og symboler

- Informations- og profileringsmaterialer

- Miljømærket butik

- Aktiviteter og dialog med kunderne

\section{Sortiment}

Sortimentet har som tidligere omtalt stor betydning for salget - der skal ganske enkelt være de varer i butikkerne, som kunderne ønsker og forventer + gerne lidt mere til, så man bliver stimuleret til at prøve nyt. Det er vigtigt for synligheden og salget af de miljøtilpassede/etiske varer at sørge for, at alle varer er hjemme, at der ikke mangler noget på hylderne, og at prismærkningen er tydelig. Det betyder også, at stabile leverancer bliver en kritisk faktor, specielt hvis der ikke er alternative miljøtilpassede/etiske varer, som den grønne kunde kan vælge. Manglende varer er et tillidsbrud, for kunderne regner med at kunne finde varerne i butikken.

\section{Placering i butikken}

Kæderne udarbejder for de flestes vedkommende fra centralt hold planogrammer for indretning af butikkerne, dvs. hvor i butikkerne de enkelte varegrupper skal placeres for at optimere salget. Et bud, som giver et rimeligt dækkende billede af prioriteringen er 1) Lønsomhed, 2) Egne varemærker, 3) Miljøtilpassede/etiske produkter. Derudover indgår nogle kæder aftaler med leverandører, som køber sig til en vis plads og placering i butikkerne, og som i visse tilfælde selv står for at indrette og fylde op på hylderne.

De mest synlige pladser i en butik er ved indgangen og langs med hovedstrøgene, der leder kunderne rundt i butikken. Nedenstående foto er fra MATAS i Allerød, Danmark og er taget lige inden for indgangsdøren. På podiet i midten står månedens tilbudsvarer, herunder også svanemærkede varer. Andre svanemærkede varegrupper står samlet og tydeligt placeret - markeret med røde pile. Den stiplede pil viser vejen til disken, og på denne vej er der endnu en svanemærket produktserie. 


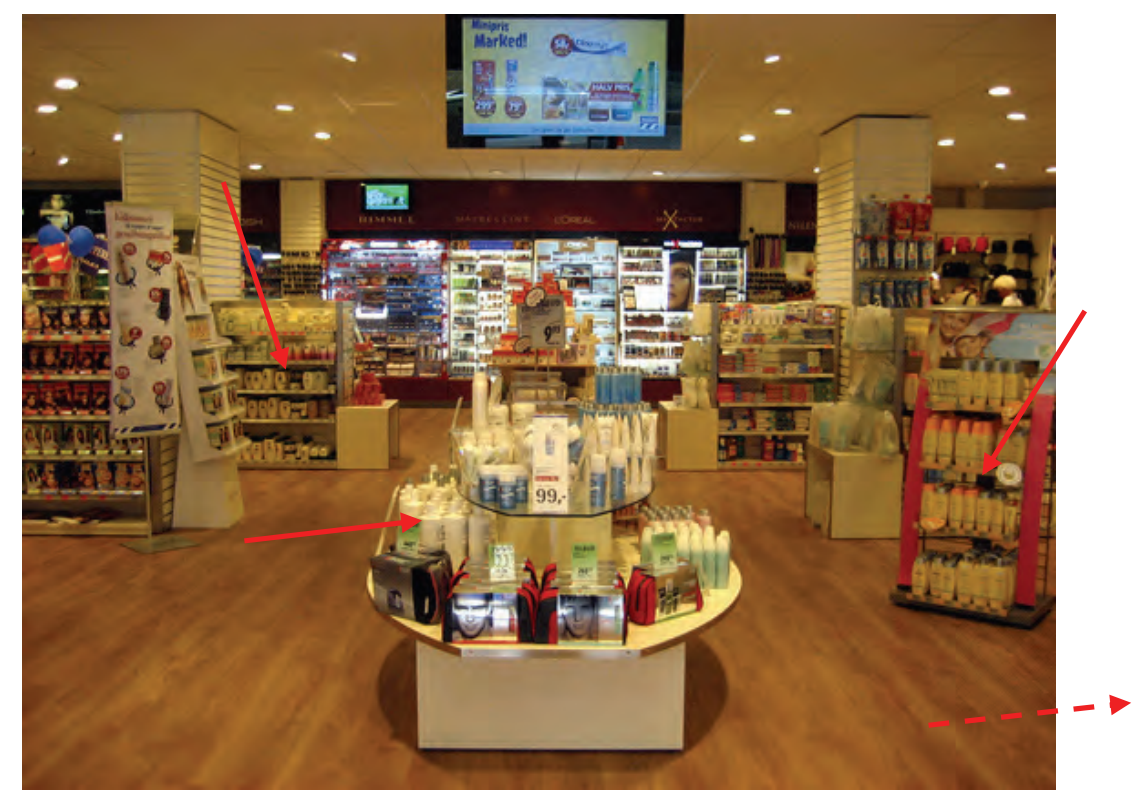

I supermarkeder, som prioriterer økologi højt, vil man ofte se, at økologisk frugt og grønt, et Øko-torv eller Øko-reoler står ulige synligt og ofte tæt på indgangen. Inden for samme kæde kan der imidlertid godt være butikker, der vælger at placere Øko-reolerne mere diskret, fordi de ikke prioriterer det lige så højt.



„Ud over at samle varerne, som er det vesentligste for at fremme salget, bruger vi skilte og Ø-symboler. I frugt og grønt afdelingen er der en hel væeg med økologi, og det er indrettet med trckasser, som signalerer noget rustikt, lidt bondegårdsagtigt. Man må gerne kunne fornemme koen, bare man ikke kan lugte den.... På Ø-væeggen fremhœver vi også, at man kan abonnere på økologiske grøntkasser, og vi har fået en kølemontre til at holde varerne mere friske“. Varehuschef Morten Houmann, Kvickly Vordingborg (Foto: Kirsten Schmidt). 


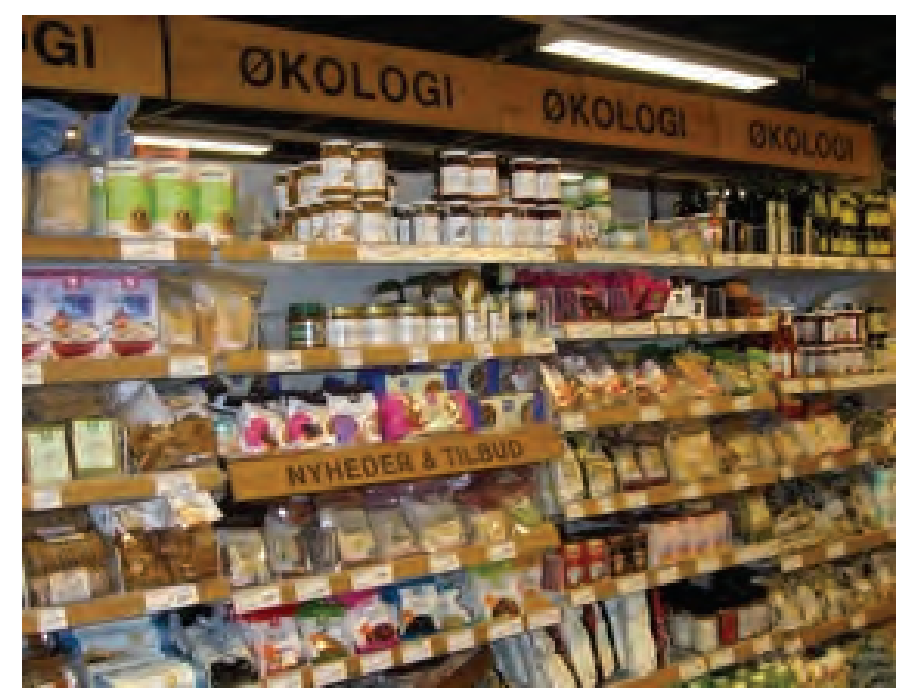

I SuperBrugsen på Nørrebro i København er pladsen trang, så der er ikke mulighed for et stort økotorv, selv om efterspørgslen er stor. I stedet fylder reolen med økologiske kolonialvarer en stor del af pladsen i den første gang, når man er kommet ind i butikken (Foto: Kirsten Schmidt).



Hos City Gross i Kalmar, Sverige, er området med økologisk frugt og grønt fremhœuet både med store skilte i loftet og med stor tekst på skiltene ved de enkelte produkter.

Indgangsområdet bliver ofte anvendt til at synliggøre ugens/månedens tilbud, og her bliver de miljøtilpassede/etiske varer også stillet frem, hvis der er kampagne for dem i tilbudsavisen. På samme måde bruges gavlene for enden af reolerne rundt $i$ butikken. 


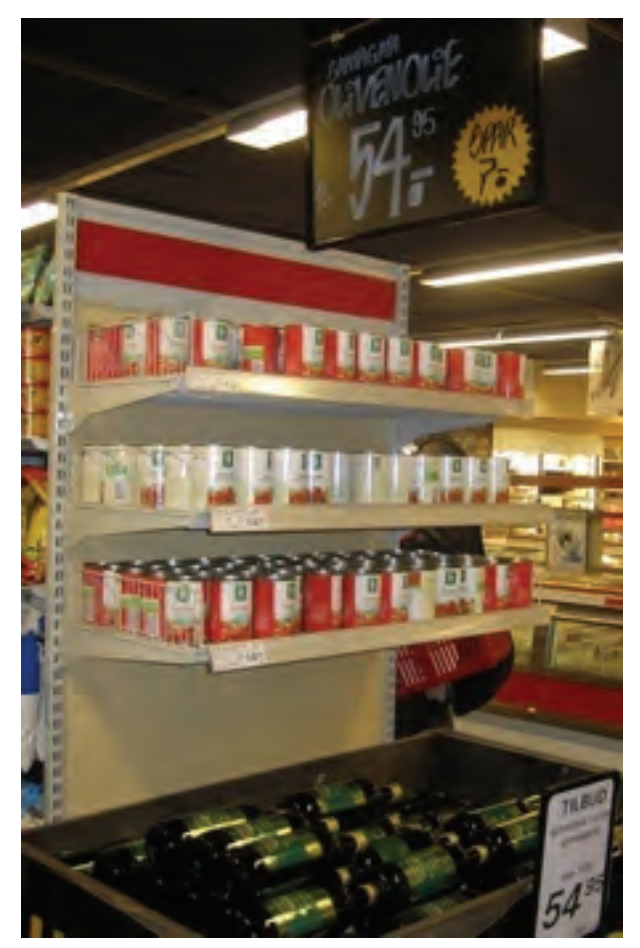

Et ugetilbud på koldpresset, italiensk olivenolie er placeret meget synligt for enden af en reol. Overover er placeret økologiske, flåede tomater, som ikke er på tilbud. Men mange forbinder olivenolie med tomater i madlavningen, så ved at fremhreve tomaterne i denne sammenhceng, bliver salget stimuleret. Set i SuperBrugsen på Nørrebro i København.(Foto: Kirsten Schmidt).

I den mere faste opstilling af varerne bliver der skabt synlighed ved at placere varerne i produktgrupper, og det gælder både for de miljøtilpassede/etiske og de konventionelle varer. I mange tilfælde står de miljøtilpassede/etiske varianter således blandet med de konventionelle. Her får forbrugerne derfor det umiddelbare valg, om de vil købe økologisk eller ikke-økologisk mel; svanemærket eller ikke mærket shampoo osv. Den faste opstilling er dog ikke permanent. I nogle butikker er der en hyppig omgruppering af varerne for at få plads til nye varer, køre kampagner osv., og så er det ikke hensigtsmæssigt med helt faste pladser. 

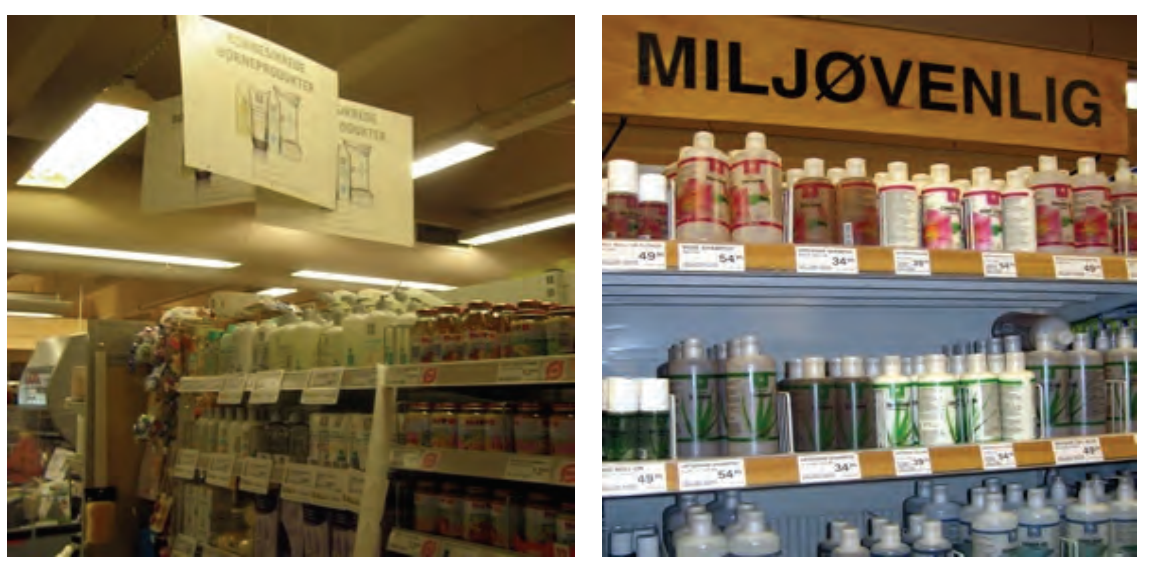

I eksemplet til venstre er børneprodukter fra Coops Änglamark-serie placeret samlet $i$ reolen for baby-produkter. Ved siden af står der babymad, hvoraf en del er økologisk. I eksemplet til højre er en relativt højtprofileret naturplejeserie samlet $i$ stedet for at stå fordelt mellem andre shampooer, sceber osv. Begge eksempler er fra SuperBrugsen, Ndr. Frihavnsgade i København (Fotos: Kirsten Schmidt).

Hvis kæden har egne private labels, bliver disse prioriteret specielt inden for produktområder, hvor der er mange/en hel serie af miljøtilpassede/etiske produkter. Disse bliver samlet, og eftersom emballagen for disse private labels produkter har et særligt design, bliver de meget synlige, når de står samlet. Disse private labels står endvidere placeret på gode pladser i butikken, så det er dobbelt op på synligheden.

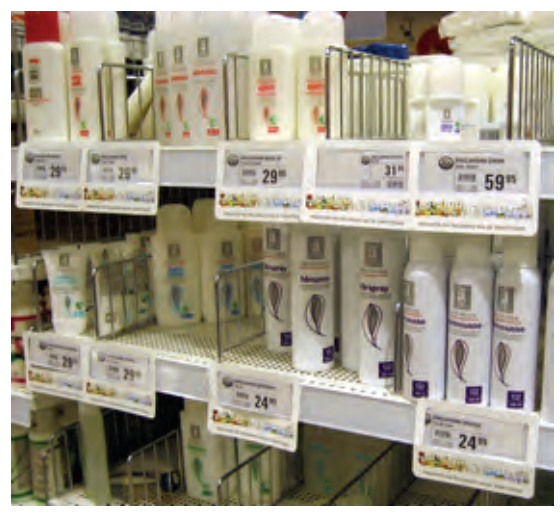

Coops Änglamark serie er meget synlig i alle Coops butikker, bl.a. på grund af det karakteristiske logo. Her fra Kvickly, Vordingborg i Danmark. (Foto: Kirsten Schmidt)

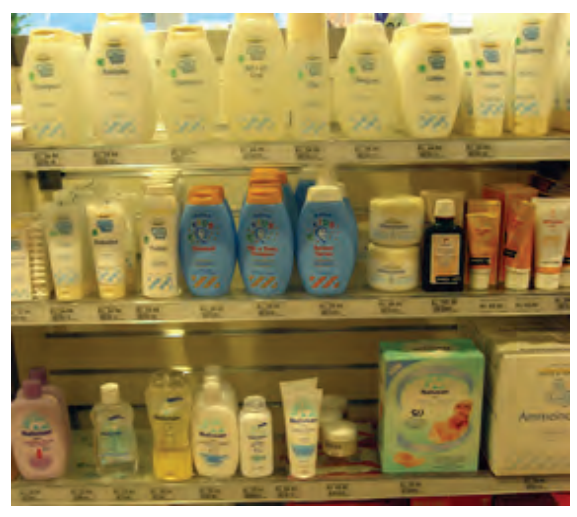

MATAS' eget varemcerke med de let genkendelige striber. Her den svanemcerkede børne-serie i MATAS, Allerød i Danmark. (Foto: Kirsten Schmidt)

På det økologiske område vælger nogle butikker både at have varerne ude på hylderne blandt de konventionelle varer og at have dem samlet, så kunderne får et bedre overblik over sortimentet. Denne tilgang påvirker salgstallene i positiv retning, men er formentlig mest hensigtsmæssig i et mere modent marked, hvor der er en god afsætning af de økologiske produkter. Disse butikker overvejer også at samle fairtrade varerne på sam- 
me måde, og det skal være ved siden af de økologiske, fordi mange fairtrade produkter også er økologiske.

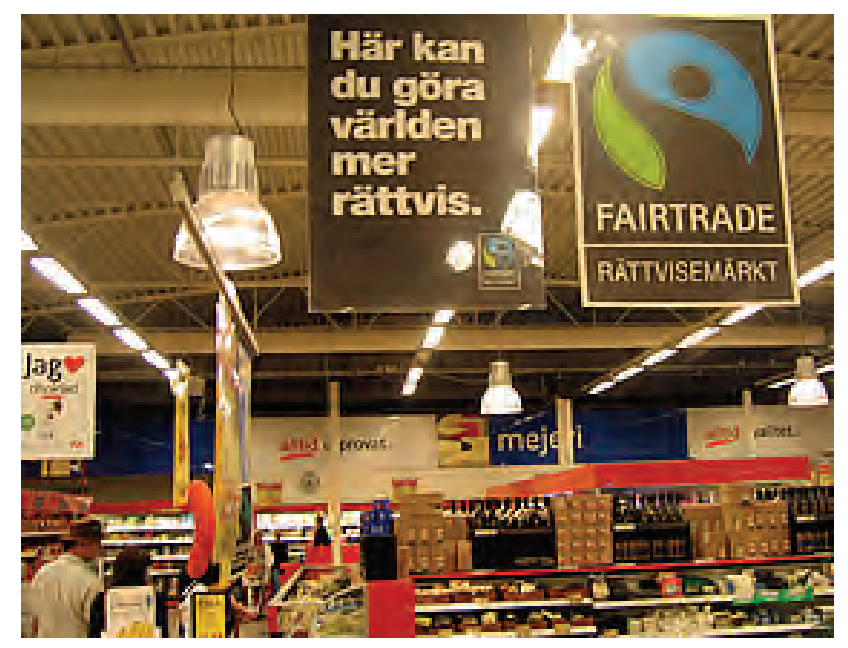

Hos ICA MAXI i Mölndal, Sverige, er fairtrade varerne tydeligt skiltet og placeret i næerheden af de økologiske varer (Foto: Christian Lindskog).

\section{Skiltning og symboler}

Sammen med volumen og placering er skiltning det vigtigste middel til at synliggøre varerne i butikkerne, og det gælder for alle varer, ikke kun de miljøtilpassede/etiske. Skiltning foregår på mange måder og i mange størrelser, hvor de største og mest synlige hænger fra loftet, så de kan ses på afstand. Disse skilte bruges både til at lede kunderne til bestemte varegrupper og til at skabe opmærksomhed om kampagner og tilbud. Førstnævnte hænger i længere tid, mens sidstnævnte skiftes ud sammen med kampagnerne/tilbuddene. På miljøområdet synes der at være en tendens til at bruge hængeskilte i forbindelse med de økologiske varer i supermarkederne, hvor det nogle gange er ordet „økologi“ og andre gange er det økologiske logo, som anvendes. Kæderne fremstiller deres egne skilte, men ens skilte på tværs af kæderne ses også, fx på fairtrade området. Her er der formentlig tale om en kampagne, som gennemføres af en organisation, og hvor flere kæder deltager.

Coop-butikkerne fremhæver endvidere deres svanemærkede Änglamark produkter via hængeskilte. Her er det ikke svane-logoet, men kædernes eget varemærke, som er i fokus. I Danmark har der i foråret 2008 kørt en Änglamark-kampagne i Coop Danmark med det formål at opbygge kendskabet til dette varemærke. I butikkerne er skiltningen ganske omfattende, fra hængeskilte til hyldeskilte og skiltning ved kasseapparaterne. Herunder er vist nogle eksempler. 


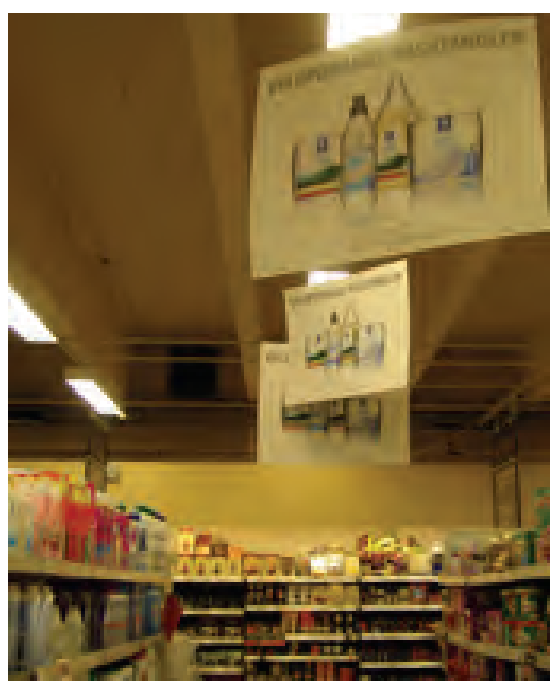

Hœengeskilte, SuperBrugsen, Ndr. Frihavnsgade i København

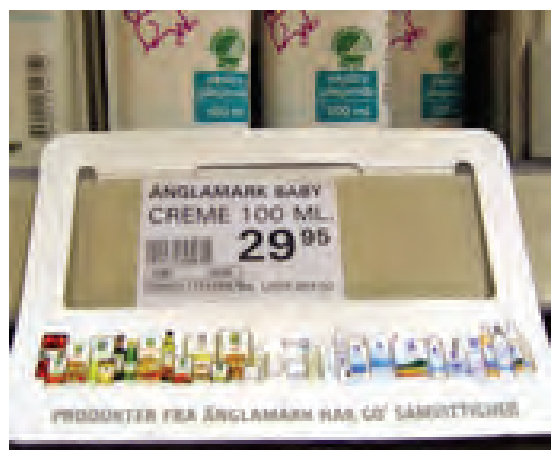

Skilt på kassebåndet, SuperBrugsen på Nørrebro i København

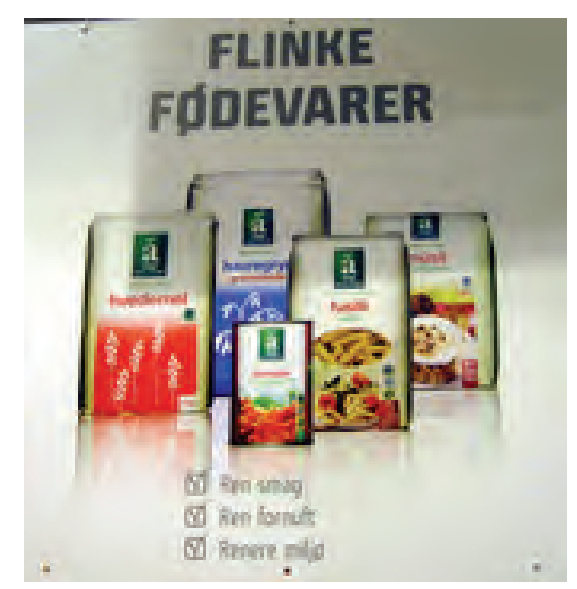

Hœngeskilt, Kvickly i Vordingborg
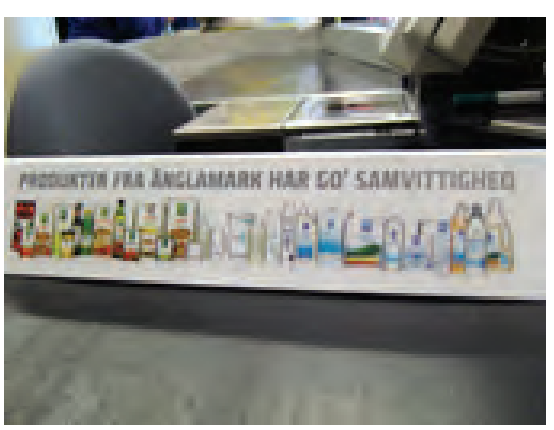

Skilt på hyldeforkant, SuperBrugsen på Nørrebro i København (Fotos: Kirsten Schmidt).

I forbindelse med kampagner eller tilbud bliver de øvrige miljøtilpassede/etiske begreber og logoer (fairtrade, FSC osv.) også anvendt på hængeskilte, mens det ikke synes at være slået igennem i den mere faste skiltning.

Næste trin i skilte-hierarkiet er mindre skilte umiddelbart i tilknytning til en varegruppe, fx over en kølemontre, som tekst på en reol eller som vippeskilte på hyldeforkanter. Disse skilte gør det lettere for kunden at finde de ønskede produkter, når først hun er i nærheden, og samtidig er de med til at fremhæve de udvalgte produkter. Også her er det mest udbredt i forhold til økologi, men svanemærket eller svanemærkede private labels er godt med. Som eksemplerne herunder viser, bliver mærkernes logoer ind i mellem brugt, men det i andre tilfælde er et ord ( $\mathrm{fx}$ „økologisk“ eller „miljømærket“) 


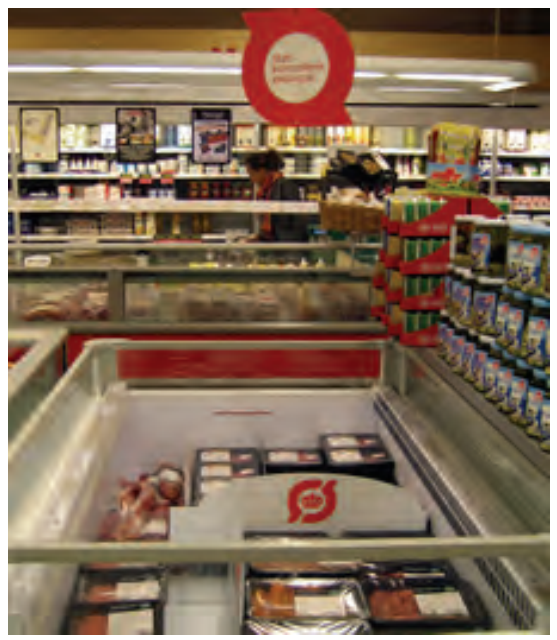

Køledisken med økologisk kød, SuperBrugsen, Ndr. Frihavnsgade i København (Foto: Kirsten Schmidt).

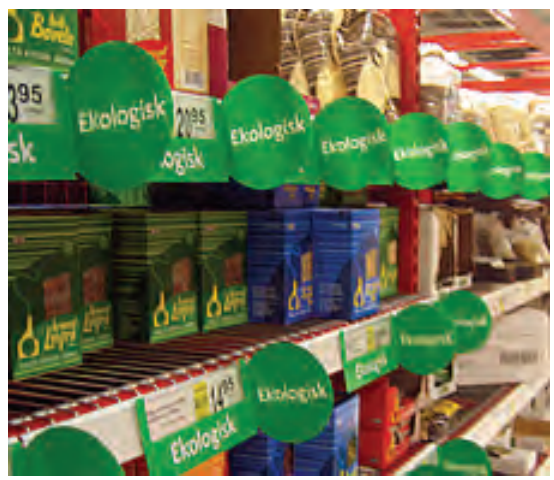

Økologiskiltning, som både kan ses forfra og på langs af hylderne. Fra ICA MAXI, Mölndal, i Sverige (Foto: Christian Lindskog).

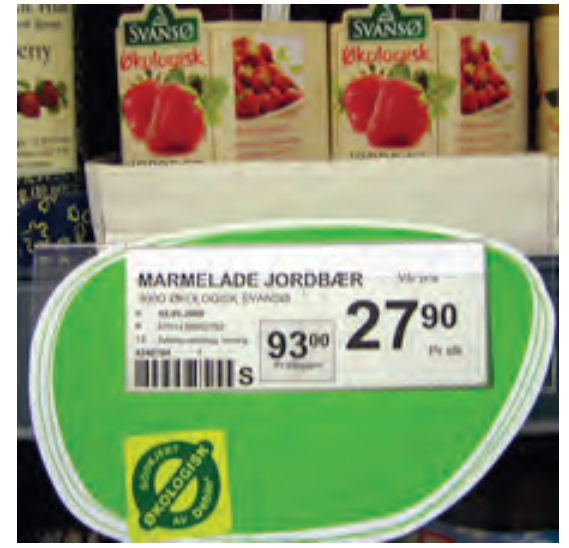

Store økologi-skilte på hyldeforkanter i Coop Mega, Fredrikstad i Norge (Foto: Hanne Møller).

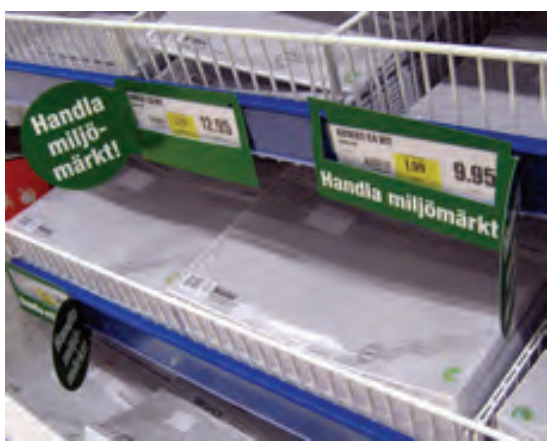

CityGross i Kalmar, Sverige fremhrever svanemerkede papirvarer på denne måde på hyldeforkanten (Foto: Kirsten Schmidt).

Tredje skiltningstrin er skilte umiddelbart ved varerne, fx på hyldeforkanter. Her står produktets pris og andre relevante informationer, og her bliver de miljøtilpassede/etiske varer ofte fremhævet med logo og/eller tekst. Visuelle logoer er mere tydelige end tekst, og dette er den mest udbredte måde at skilte med de miljøtilpassede/etiske varer. De mest kendte eller mest omtalte typer miljøtilpassede/etiske varer (økologi, svanemærket og fairtrade) er mest synlige, men der er nationale forskelle, idet svanemærket bruges aktivt på hyldeforkanter i Sverige og Norge, mens det ikke er tilfældet i Danmark. Nedenstående er eksempler på diskret skiltning. 


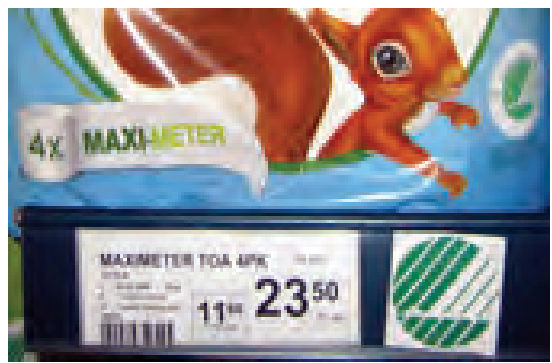

Svanemæerket toiletpapir i Coop Mega, Fredrikstad i Norge (Foto: Hanne Møller).

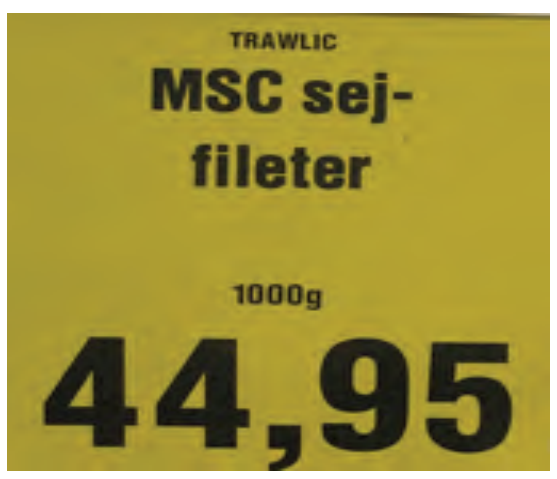

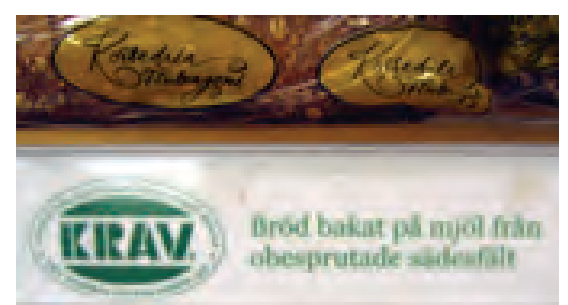

Økologisk, KRAV-mcerket brød i ICA MAXI, Mölndal, Sverige (Foto: Christian Lindskog).

MSC-mœrket fisk hos et dansk discountsupermarked (Foto: Kirsten Schmidt).

Ud over selve skiltningen fungerer logoer på produktemballagen også som en form for skiltning. Her synes der at være sket en ændring over tid, hvor de miljøtilpassede/etiske logoer efterhånden som de er slået mere igennem, også bliver større og placeret mere synligt på emballagen. Når mange produkter med det samme logo står samlet opnår logoet en synlighed, der er større end et enkelt logo på hyldeforkanten.



Fairtrade mærket appelsinjuice i Meny, Fredrikstad i Norge. Fairtrade-logoet på emballagen er større end det tilsvarende logo på hyldeforkanten (Foto: Hanne Møller.) 
Den store udfordring i forhold til skiltning er at opnå en balance mellem at vejlede kunderne og at skilte så meget, at det i stedet skaber skilteskov med en overflod af information. Hvis man fremhæver for meget kan man ende med at kunderne i stedet ignorerer skiltene. Hvilke typer miljøtilpassede/etiske produkter, der „vinder” i skiltekonkurrencen, synes at hænge sammen med, hvor længe de har været på markedet, så de ældste har den mest omfattende basis-skiltning. Derudover spiller aktuelle trends også ind, idet butikkerne i sagens natur gerne fremhæver de varer, som forbrugerne viser interesse for. De nye miljø/etiske mærker skal først arbejde sig ind i hierarkiet, og her går vejen gennem kampagner og tilbud, når det handler om skiltning. Kampagner er i det hele taget en mulighed for at bruge flere virkemidler også inden for skiltning og symboler. Fx skiltning uden for butikkerne, skilte på diskene, ophængte TV-skærme samt badges, som personalet bærer på tøjet.

Coop i Sverige har valgt at bruge et helt særligt symbol - en grøn trekløver - for de miljøtilpassede varer, og dette symbol bruges på varen, på hyldeforkanterne, i opskrifter på kasseboner, osv. Ved at anvende symbolet på kassebonen får kunden et overblik over omfanget af sit miljøtilpassede indkøb, hvilket de bevidste forbrugere giver udtryk for, at de er glade for.
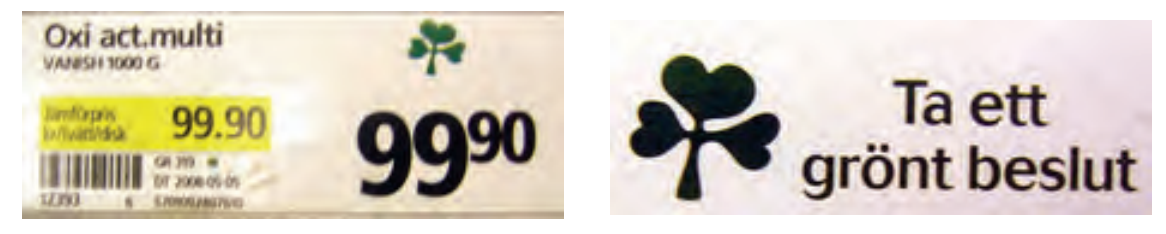

(Fotos: Christian Lindskog)

I forhold til de miljøtilpassede/etiske varer er der en særlig form for skiltning, som synes at være udbredt - nemlig informationsskilte. Disse skilte er placeret et synligt sted i butikken, fx ved indgangen, bag disken, ved kasseapparatet eller i tilknytning til en varegruppe. Skiltene giver baggrundsinformation og forklarer fx hvad økologi eller fairtrade er, og henviser i nogle tilfælde til hjemmesider, hvor man kan få mere information. (Se eksempler i afsnit 6.3)

Kæderne fremhæver i interviewene, at der er et stort behov for information, når det handler om de miljøtilpassede/etiske varer, og det gælder både før kunderne kommer i butikken, og når de er der. Hovedparten af informationsmaterialet bliver udarbejdet centralt, men undersøgelsen har vist, at enkelte butikker vælger at supplere med yderligere informationsskilte, som de selv har fremstillet. 


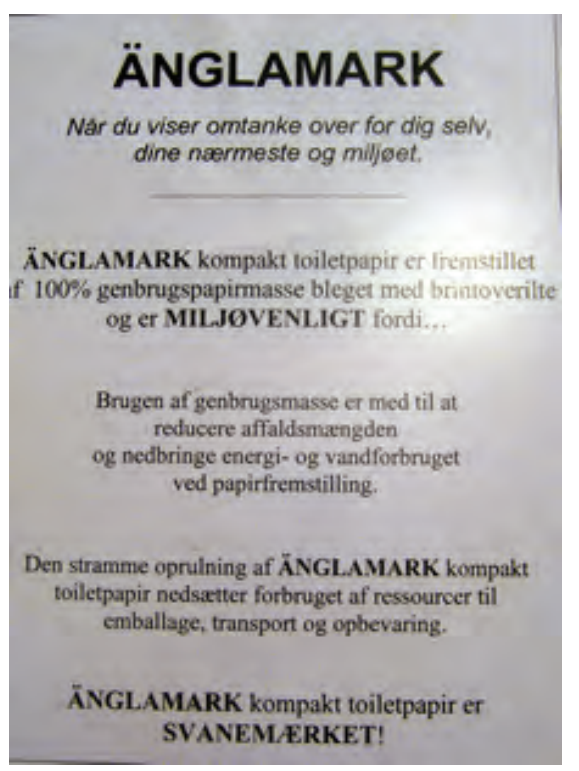

SuperBrugsen på Nørrebro i København har sat ekstra skiltning op for nogle af Änglamark-produkterne for at fremhœeve disse i forhold til andre miljømœerkede produkter (Foto: Kirsten Schmidt).

Samlet set er der således en ret omfattende skiltning af de miljøtilpassede/etiske varer, men der er store variationer både i omfang, i typen af skilte, mellem de forskellige miljøtilpassede/etiske varegrupper, mellem kæderne og mellem landene. Det er i høj grad her, den enkelte kædes „personlighed“ kommer til udtryk. Det viser sig også ved, at nogle kæder ikke blot fremhæver produkterne, men også deres holdning til og prioritering af indsatsen. Det skal være let for kunderne at finde de miljøtilpassede/etiske varer i butikken, men de bevidste kunder skal også styrkes i, at de har valgt „den rigtige butik“ at handle i.
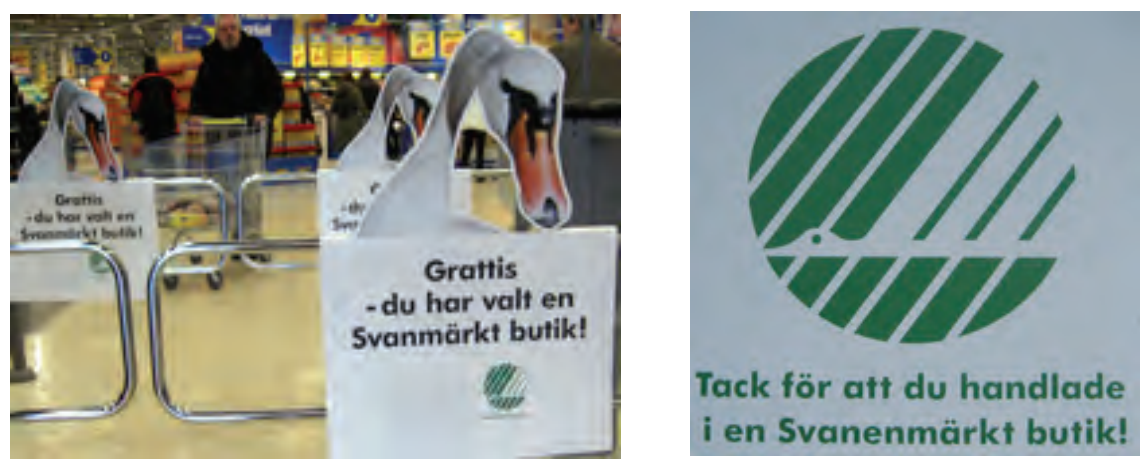

City Gross i Kalmar, Sverige, gør meget ud af at fortclle kunderne, at butikken er svanemcerket - både når de er på vej ind i og på vej ud af butikken (Fotos: Kirsten Schmidt). 


\section{Informations- og profileringsmaterialer}

Netop fordi behovet for information er stort, når det drejer sig om de miljøtilpassede/etiske varer, vælger flere kæder at udarbejde foldere og lignende, som er tilgængelige i butikkerne.

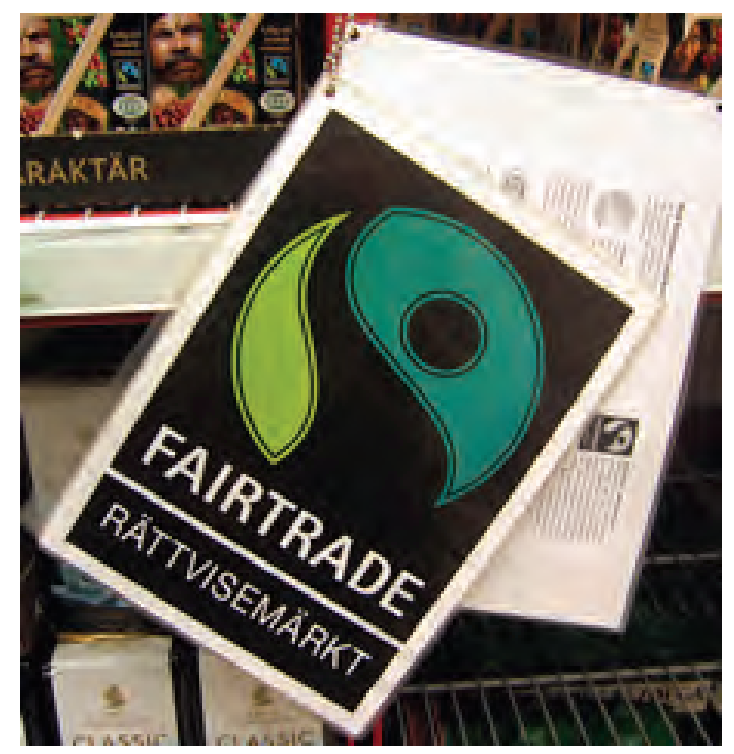

Information om fairtrade hæengt op ved kaffehylden i ICA MAXI, Mölndal, Sverige. Bemerk, at det ikke kun er fairtrade, som bliver forklaret, men også andre mcerker som svanen og KRAV (Foto: Christian Lindskog).

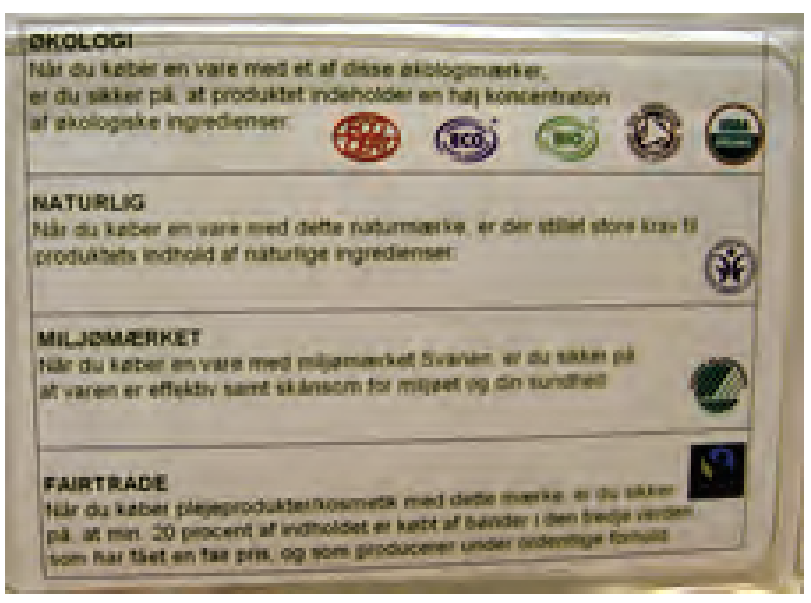

MATAS har ligeledes valgt en holistisk tilgang, hvor man forklarer forskellige begreber på skilte, og samtidig bliver personalet uddannet $i$ at forstå og forklare de forskellige mcerker og hvad de står for. Her et skilt fra MATAS, Bryggen i Vejle, Danmark, hvor de forskellige marker i tilknytning til kosmetik bliver forklaret.(Foto: Kirsten Schmidt).

Det kan være generelt om kædens indsats, om en speciel kampagne eller projekt, eller om en given produkttype. Folderne har den fordel, at kunderne kan tage dem med sig, og de kan bruges aktivt i dialogen mellem de ansatte og kunderne. Levende medier som TV-skærme bliver ligeledes 
brugt til at give information, fx om hvad økologi er, eller hvorfor en kæde har valgt ikke længere at forhandle æg fra burhøns. Billedmediet er en stærk måde at formidle følelser og koble forbrugerne mere direkte sammen med oprindelse af varerne eller hvordan de er blevet produceret.

Poser og emballage bruges aktivt som medie til at signalere holdninger. Det kan være gaveæsker med et tydeligt logo og/eller slogan, hvor indpakningen er med til at skabe værdi til produkter, fordi den formidler en holdning. Endvidere sælger flere kæder genbrugsposer med slogans, hvor selve det at bruge poserne flere gange er udtryk for en miljøbevidst holdning. I nogle tilfælde giver kunderne et bidrag til en særlig sag ved at købe genbrugsposerne.

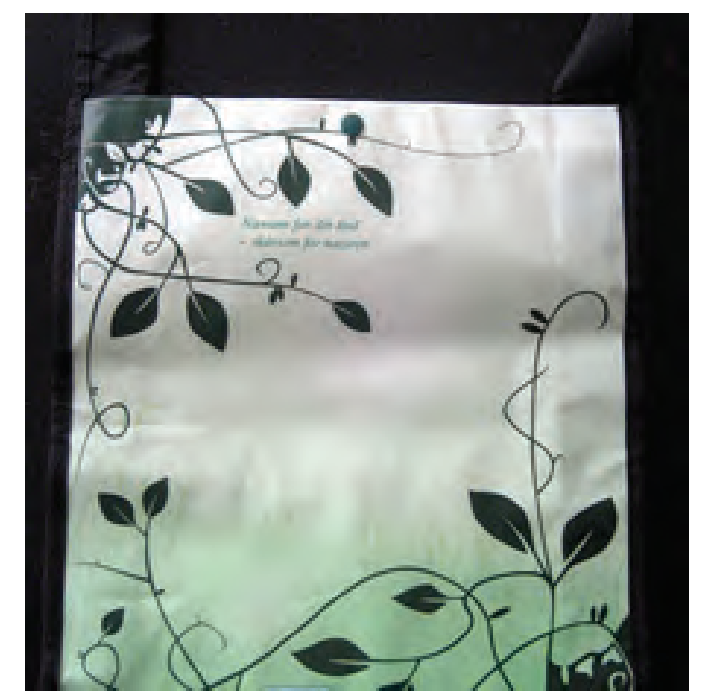

MATAS' miljøposer (indkøbstasker) scelges til fordel for MATAS' miljøfond, som donerer buske og trceer til børns legepladser. Indkøbstaskerne er lavet af genanvendt materiale og kan bruges mange flere gange end en almindelig plasticpose (Foto: Kirsten Schmidt).

Økologiske og fairtrade fødevarer bliver desuden profileret via særlige opskrifter eller kogebøger, som er baseret på disse ingredienser. Det er med til at stimulere kundernes nysgerrighed, men også viden om, hvor mange produkter, der findes i en miljøtilpasset/etisk variant. Nogle kæder samarbejder med kendte kokke, som således er med til at give såvel kæden som de pågældende varer et kvalitets- og smagsmæssigt blåstempel maden skal også være en oplevelse.

\section{Miljømærket butik}

Antallet af svanemærkede butikker i Norge og Sverige er stigende, mens der ikke er nogen i Danmark - af flere årsager. For det første er afgiftssystemet på nuværende tidspunkt forskelligt, så norske og svenske butikker betaler en fast afgift til miljømærkeordningen, mens de danske skal betale en \%-afgift af den samlede omsætning, dvs. af alle varer ikke kun de svanemærkede, hvilket gør det meget dyrt. Der er kommet en ny be- 
kendtgørelse, som gør det muligt at ændre det danske system, men det er et spørgsmål, om det får kæderne til at søge om at blive svanemærkede.

Forbeholdene handler også om, at:

„svanemærket er først og fremmest profilering, og vi er allerede kendt for Danmarks største udvalg af miljøtilpassede varer“

Miljøchef Katrine Milman, Coop Danmark.

Endvidere opfatter nogle det som vildledning af forbrugerne, fordi der i en svanemærket butik sagtens kan være rigtig mange konventionelle produkter. Svanemærkede butikker forpligter sig til at have et vist sortiment af miljømærkede varer, men der er ikke specifikke krav til omfanget.

I Sverige og Norge er der gennemført interviews i miljøcertificerede butikker, men ingen af de interviewede nævner selv dette faktum. Det kunne tyde på, at man ikke tillægger det en stor og bevidst betydning i butikkerne, men at det ligger som en ramme for indsatsen. Eftersom stadig flere kæder/butikker vælger at blive miljøcertificeret er den største betydning muligvis i en opstartsfase, hvor kæden har besluttet at gøre en særlig indsats og nu skal til at konkretisere denne.

\section{Aktiviteter og dialog med kunderne}

Især de interviewede specialbutikker giver udtryk for, at dialogen mellem de ansatte og kunderne har stor betydning for at kunderne vælger de miljøtilpassede/etiske produkter. Dette hænger formentlig sammen med, at vejledning af kunderne i det hele taget er vigtigere i specialbutikkerne end i supermarkederne.

Butikkerne gennemfører også aktiviteter - typisk i forbindelse med en kampagne eller særligt tilbud - hvor der sker noget, dvs. hvor kunderne bliver mere aktivt involveret. På fødevareområdet kan det fx være uddeling af smagsprøver, så kunderne kan prøve produktet, hvilket specielt er egnet, når der er tale om små og ikke så kendte leverandører. Uddeling af non-food vareprøver bruges også ved (re)lancering af produkter, men det er dyrt, eftersom det koster næsten lige så meget at producere de små vareprøver som de almindelige størrelser. Uddeling af smags- og vareprøver synes ikke at være mere eller mindre udbredt på det miljøtilpassede/etiske område end på det konventionelle. 


\section{Diskussion og perspektiver}

Dette sidste kapitel samler op på resultaterne af undersøgelsen og diskuterer, hvad best practice for afsætning af miljøtilpassede/etiske produkter synes at være i den nordiske detailhandel baseret på de fundne eksempler; hvilke forskelle og ligheder, der er mellem de enkelte lande og de forskellige varegrupper (økologiske, fairtrade, svanemærkede osv.); samt hvordan salget af de miljøtilpassede/etiske varer kan fremmes yderligere.

Bemærk, at i denne rapport bruges begrebet „Miljøtilpassede/etiske produkter" som en fælles betegnelse for produkter, hvor der er taget miljømæssige og/eller sociale hensyn, og som er godkendt/mærket af en uvildig 3. part.

\subsection{Diskussion af best practice}

Best practice i forhold til at sælge miljøtilpassede produkter ses på flere niveauer - fra den strategiske ledelsestilgang over vidensopbygning og samarbejde - og til omsætning af strategierne i praksis. Denne undersøgelse har haft til formål at afdække eksempler på best practice, og diskussionerne i dette afsnit er derfor udtryk for tendenser mere end entydige konklusioner, som er dækkende for hele den nordiske detailhandel.

\subsubsection{Den strategiske tilgang}

Set udefra synes der at være flere holdninger og strategiske tilgange i detailhandelen, når det drejer sig om bæredygtig udvikling:

- Den komplette butik, som udelukkende forhandler miljøtilpassede/ etiske varer

- Butikken/kæden som garant for miljøtilpasset/etisk adfærd, dvs. at de miljø- og etisk bevidste forbrugere i lige så høj grad vælger butikken som de miljøtilpassede/etiske produkter. Nogle kæder vælger at synliggøre indsatsen direkte på produkterne, mens andre ikke gør. Disse butikker forhandler både miljøtilpassede/etiske som konventionelle produkter

- Kæden satser på miljøtilpassede/etiske produkter inden for et specialområde i sortimentet, og det er dette specialområde, som bliver brugt i brandingen over for de bevidste kunder

- Kæden tester markedet med udvalgte miljøtilpassede/etiske produkter og forventer at udvide sortimentet, hvis forbrugernes reaktion er positiv. Dette er hvor de fleste specialbutikker, fx tøjbutikker, starter 
- Kæden ønsker ikke at satse på miljø/etik, men eftersom nogle forbrugere efterspørger miljøtilpassede/etiske produkter, har kæden nogle få produkter som en form for risikogardering, men har i øvrigt ingen intentioner om at udvide sortimentet i nævneværdig grad.

I denne undersøgelse er der fokuseret på de 3 midterste tilgange, fordi de er mest repræsentative for den del af detailhandelen, som har en aktiv, forretningsmæssig tilgang til miljø og social ansvarlighed, og som forhandler såvel miljøtilpassede/etiske som konventionelle produkter. Denne gruppe ønsker generelt at give kunderne et reelt valg. Både de miljøbevidste og de ikke miljøbevidste forbrugere skal føle sig velkomne i butikkerne.

\section{Leaders \& Followers}

Ser man nærmere på kædernes tilgang, er det relevant at skelne mellem „Leaders“ og „Followers“. Leaders er dem, der løber markedet i gang, mens Followers kommer med senere og er så med til at skabe volumen. Leaders er endvidere kendetegnet ved, at de opbygger miljøbrands, dvs. at de søger at tiltrække de miljø/etisk bevidste forbrugere. De bagved liggende ledelsesbeslutninger er baseret på holdninger, men samtidig handler det om forretning - ikke om filantropi. Leaders har erkendt, at det tager tid og kræver en vedvarende indsats med langsigtede investeringer at opbygge et marked for miljøtilpassede/etiske produkter. I hvert tilfælde hvis markedet skal opnå et vist volumen og ikke kun være en niche, som henvender sig til ganske få procent af forbrugerne.

Opbygningen af miljøbrandet hos leaders sker blandt andet ved at skabe et værdifællesskab med kunderne, hvor de miljøbevidste forbrugere har tillid til, at butikken sørger for et ordentligt sortiment af miljøtilpassede/etiske varer, og at disse - ofte dyrere - varer også reelt er bedre. Troværdigheden er vigtig, og her er detailhandelen afhængige af, at myndigheder og organisationer bag de forskellige mærkningsordninger populært sagt „har styr på sagerne“.

Eftersom udvikling af et marked for miljøtilpassede/etiske produkter er en proces, er det vigtigt med en vis dynamik. Der skal nye, spændende produkter på hylderne, og kvaliteten skal være høj. Derfor har leader-kæderne også et tæt og normalt langvarigt samarbejde med centrale leverandører.

Et marked af en vis størrelse og med god vækst lokker Followerkæderne til. De ønsker en bid af kagen, men har også en reel betydning for den fortsatte udvikling af markedet. For det første er de med til at skabe større volumen og større synlighed, og for det andet stimulerer de konkurrencen. Både ved at presse priserne og ved at skabe et større udvalg af miljøtilpassede/etiske varer.

\section{Prisscetning}

Undersøgelsen har vist, at prissætningen af de miljøtilpassede/etiske varer varierer fra kæde til kæde, og der synes heller ikke at være nationalt base- 
rede mønstre. Alle er enige om, at det handler om at undgå, at de miljøtilpassede/etiske varer bliver væsentligt dyrere end de konventionelle produkter, for jo større prisforskel, jo sværere er det at sælge de miljøtilpassede/etiske varer. Nogle typer prissætning sigter mod at eliminere eller minimere prisbarrieren, andre fokuserer på at fastholde de miljøbevidste kunder, mens atter andre følger almindelige markedsmekanismer, hvor prisen bliver fastsat efter kundernes betalingsvillighed. Den enkelte kæde kan arbejde med prissætning på flere forskellige måder, bl.a. i forhold til forskellige varegrupper og segmentering af forbrugerne.

Alle de interviewede kæder melder om stor vækst på markedet for miljøtilpassede/etiske produkter. Især synes økologi og fairtrade at boome, næsten uden at detailhandelen gør noget særligt for det. Kæderne har travlt med at følge med efterspørgslen, men leaders går desuden bevidst efter at få flere miljøbevidste stamkunder, som - forhåbentlig - fastholder deres forbrug også på sigt.

\section{Barrierer i markedet}

Selv om der på nuværende tidspunkt er stor vækst på markedet for miljøtilpassede/etiske produkter, peger kæderne på, at såvel forbrugernes som de ansattes viden om og kendskab til de miljøtilpassede/etiske produkter stadig skal videreudvikles. På visse områder er der opnået et basalt kendskab til de mest udbredte mærkningsordninger som svanemærket, økologi og fairtrade, men der er stadig plads til forbedringer. Både i forhold til mere dybtgående viden om, hvad mærkerne står for, og i forhold til viden om de nyere mærker som FSC og MSC. Sammenlignet med markedet for de konventionelle produkter synes markedet for de miljøtilpassede/etiske produkter at være ret videntungt, og en væsentlig del af markedsføringen handler om information mere end om produktanprisninger. Mærkernes troværdighed kan ligeledes være en barriere, hvilket fx ses i Norge, hvor der er en udbredt skepsis over for FSC-mærket.

Prisen er en anden velkendt barriere, men dette skal nuanceres. Inden for nogle produktgrupper, fx økologisk mælk, er prisforskellen lille, og markedsandelen er efterhånden blevet stor. Ligeledes er der en stigende gruppe af forbrugere, som har foretaget et bevidst tilvalg af de miljøtilpassede/etiske produkter, og som er villige til at betale merprisen. Omvendt er der en gruppe af forbrugere, som stort set kun går efter prisen, og som ikke vil betale ekstra for økologi eller lignende. I Danmark melder detailhandelen nu om, at der synes at være sket en polarisering mellem de to forbrugergrupper, idet både discountvarerne og de økologiske varer er i vækst, mens varerne „i midten” går tilbage. Selv om fødevarepriserne er steget en del det sidste år, og forbrugerne generelt er blevet mere tilbageholdende, så vokser markedet for økologi stadig ${ }^{10}$.

\footnotetext{
${ }^{10}$ www.jp.dk, 14. september 2008. Vi har ikke oplysninger fra de andre lande, om der tegner sig et lignende billede der.
} 


\section{Samarbejde}

Som nævnt er viden og troværdighed væsentlige aspekter ved opbygning og udvikling af markedet for miljøtilpassede/etiske produkter. Derfor har leader-kæderne også et ganske omfattende samarbejde med eksterne parter som myndigheder, forbrugerorganisationer, NGO'er og andre faglige eksperter. Disse er vigtige kilder til viden om miljø og sociale forhold og om forbrugernes præferencer, og de er samtidig med til at øge synligheden og troværdigheden af kædernes indsats.

Det interne samarbejde i kæderne spiller også en rolle, idet personer på kædernes centrale niveau er med til at opbygge og sprede viden til butikkerne, mens butikkerne omvendt er vigtige for at opsamle kundernes spørgsmål og ønsker, bl.a. til nye produkter. Det centrale niveau er typisk igangsættere og dem, der skaber fælles rammer og minimumsstandarder i butikkerne, mens den konkrete indstilling og indsats ude i butikkerne er af stor betydning for, hvor hurtigt de miljøtilpassede/etiske varer slår igennem. Der synes således at være en tendens til, på butiksniveau, at jo mere de ansatte i den enkelte butik taler om miljø og sociale forhold, jo mere fokus og jo større salg er der i de miljøtilpassede/etiske produkter.

\subsubsection{Fra strategi til handling}

Når detailhandelen omsætter strategierne til handling - og dermed salg - i butikkerne, drejer det sig om 3 aspekter: sortiment, synlighed og markedsføring. Det er overordnet set ikke forskelligt fra praksis i almindelighed, så nedenfor er der fokuseret på de forhold, som er specifikke for de miljøtilpassede/etiske varer.

\section{Sortiment}

„Babyfaktoren“ spiller en stor rolle på det miljøtilpassede/etiske marked. Forældre ønsker at beskytte deres børn, og det får mange til at gå efter „rene“ produkter (næsten) uden kemi, fx svanemærket shampoo, blomstmærket tøj og økologisk barnemad. I butikkerne ses det tydeligt ved, at der er et stort miljøtilpasset sortiment, både i bredden (= mange forskellige produkter) og i dybden (= flere alternativer inden for samme produkttype). Effekten holder også, når børnene bliver lidt større, så der er ligeledes et pænt sortiment og gode markedsandele for økologiske produkter, der henvender sig til børnefamilier - ikke mindst mælk.

Det miljøtilpassede/etiske marked er blevet mere modent, og det slår igennem i sortimentet på flere måder. Stadig flere produkter findes i en eller flere miljøtilpassede/etiske variant(er), så i dag er det muligt i velassorterede supermarkeder at dække størstedelen af en almindelig husholdnings basisforbrug med miljøtilpassede/etiske varer. Desuden satser leaders på at raffinere udvalget, specielt på fødevareområdet, så: 
- det også omfatter luksusvarer,

- det er muligt at tilberede et helt økologisk måltid selv om man ikke er vegetar

- der kommer flere forarbejdede produkter, fx økologiske færdigretter til de travle børnefamilier.

I det hele taget er det vigtigt for leaders at udvikle og forny sortimentet løbende for at fastholde interessen hos de miljø/etisk bevidste forbrugere. Samtidig skal kvaliteten være i top, og det gælder alle typer miljøtilpassede/etiske produkter. Med få mulige undtagelser, køber forbrugerne ikke miljøtilpassede produkter alene for miljøets skyld. Ifølge detailhandelen forventer de en merværdi, fx i form af ekstra god kvalitet, længere holdbarhed, bedre sundhed eller andet.

For at leve op til forbrugernes forventning om løbende fornyelse er det vigtigt for detailhandelen at have et godt samarbejde med leverandørerne - både mærkevareleverandører og producenter af supermarkedernes private labels. Men produktudviklingen skal spille sammen med pris og kvalitet, og detailhandelen stiller ret specifikke krav, når det handler om deres egne private labels. Alt andet lige taler det for at etablere og vedligeholde gode og længerevarende samarbejdsrelationer med leverandørerne - hvilke på den anden side ikke udelukker, at indkøberne i detailhandelen shopper efter enkeltstående, gode tilbud, også når det handler om miljøtilpassede/etiske varer.

Synlighed - segmentering:

Med et udtryk lånt fra detailhandelen, kan de miljø/etisk bevidste forbrugere deles op de „de grønne“ og „de blå“.

De Blå forbrugere

- vil gerne prøve en miljøtilpasset/etisk variant, hvis det ikke er for besværligt eller anderledes

- ønsker synlig merværdi, hvis de skal vælge noget andet end det, de plejer

- er ikke villige til at betale (ret meget) ekstra - prisen er en reel barriere

- er mest tilbøjelige til at prøve de miljøtilpassede/etiske varianter inden for basisvarerne. Bl.a. fordi det normalt er her, prisdifferencen er mindst

- skal møde de miljøtilpassede/etiske varer blandt de konventionelle varer, hvis de skal ned i indkøbskurven. De Blå bliver ikke umiddelbart tiltrukket af særlige områder med fx økologiske eller fairtrade varer, for det er ikke et vigtigt handlemotiv for dem

De Grønne forbrugere

- går bevidst efter de miljøtilpassede/etiske varer

- er villige til at betale en merpris, da de har gjort op med sig selv, at der er en merværdi 
- er nysgerrige og ønsker at blive udfordret løbende med nye, miljøtilpassede/etiske produkter, som de kan udvide deres indkøb med

- forventer at de miljøtilpassede/etiske varer er på hylderne og at sortimentet er så stort, at de ikke behøver at handle flere forskellige steder for at få deres behov dækket

- køber mere hvis de miljøtilpassede/etiske varer står samlet - så får de øje på nye produkter, som de også lige skal prøve

Kæderne med en leader-strategi har en interesse i at fokusere på de Grønne forbrugere. Det er dem, der er med til at drive udviklingen på markedet bl.a. ved at efterspørge nye produkter og ved at være villige til at betale en merpris. Men de Blå forbrugere er også vigtige for forretningsudviklingen, fordi antallet af dem er langt større, og de bidrager derfor til at skabe og udbygge et markedsmæssigt volumen. For kæderne med en follower-strategi synes det umiddelbart at være mest logisk at satse på de Blå forbrugere og dermed på den type miljøtilpassede/etiske produkter, hvor prisdifferencen er mindst. Det er dog væsentligt at nuancere dette, da undersøgelsen også har fundet eksempler på, at en leader-kæde har valgt at eliminere prisdifferencen ved at fordele de ekstra omkostninger til udvikling, dyrere råvarer mm. på alle produkter - konventionelle såvel som miljøtilpassede.

\section{Synlighed i butikken}

Synlighed i butikken er vigtig for salget af de miljøtilpassede/etiske produkter - som for alle andre produkter. Eksemplerne fundet i denne undersøgelse tyder på, at følgende parametre har betydning for at fremme salget af de miljøtilpassede/etiske produkter:

- Stort volumen, så de miljøtilpassede/etiske produkter fylder og er meget synlige. Her har store butikker en fordel frem for små butikker. Mange kæder har krav om, at et bestemt sortiment af varer - konventionelle såvel som miljøtilpassede/etiske - skal findes i alle kædens butikker, og dermed kan det være svært for en lille butik at skaffe plads til et ekstra sortiment af miljøtilpassede/etiske varer, selv om disse godt kunne sælges: „Hvis vi havde plads til mere, kunne vi også sælge mere“.

- God placering af varerne, dvs. at forbrugerne let skal kunne finde de ønskede, miljøtilpassede/etiske produkter. Hvad der er en god placering afhænger bl.a. af, om man har fokus på de Blå eller de Grønne forbrugere, som beskrevet ovenfor.

- Tydelig skiltning på flere niveauer. Eftersom mængden af de miljøtilpassede/etiske produkter samlet set stadig udgør en begrænset del af butikkernes sortiment, er det vigtigt med skiltning, som gør det let for forbrugerne at finde frem til de ønskede produkter - både hvis de skal finde hen til et bestemt område af butikken, og når de står ved en 
hylde og ønsker at vælge fx en økologisk dåse tomater frem for en konventionel

- Variation over tid skaber opmærksomhed. Hvis varerne hele tiden står de samme steder bliver de en vane, og dermed lettere at overse. De miljøtilpassede/etiske varer skal „frem i lyset“ $f x$ via tilbud eller nye placeringer, så forbrugerne lægger mere mærke til dem. Dette er i øvrigt ikke anderledes end for konventionelle produkter, som butikken ønsker at fremme salget af

- Prioritering i hele butikken. Når der er kampagne for udvalgte, miljøtilpassede/etiske produkter, har det en stimulerende effekt på salget, hvis forbrugeren møder produkterne flere steder, hvilket kræver koordinering mellem de ansvarlige for butikkens forskellige områder.

\section{Markedsføring}

Al markedsføring handler om at skabe opmærksomhed om produkterne, så forbrugernes købelyst bliver stimuleret. Det samme gælder for de miljøtilpassede/etiske produkter, men der er et par områder, hvor markedsføringen af disse produkter skiller sig ud.

For det første er der behov for store mængder information om dels de mærker, der står som garant for troværdigheden af de miljøtilpassede/etiske produkter, og dels om hvordan de miljøtilpassede/etiske produkter er anderledes/bedre end de konventionelle. Det betyder, at detailhandelen bruger en del reklameplads på baggrundsinformation mere end på oplysninger om det givne produkts funktioner og andre karakteristika. Forbrugernes kendskab og tillid til de miljøtilpassede/etiske produkter skal bygges op, og det tager ganske lang tid og mange ressourcer.

Vægtningen af information betyder også, at nogle kæder bruger ressourcer på at deltage på konferencer og arrangementer for at profilere deres holdninger og indsats - og dermed støtte op om markedsføringen af de miljøtilpassede/etiske produkter. Ligeledes deltager flere kæder i kampagner, som organisationer, myndigheder og andre holder for at fremme kendskabet til en bestemt mærkningsordning. Her har organisationerne og detailhandelen en fælles interesse $\mathrm{i}$ at udvide markedsgrundlaget, og dermed er sådanne kampagner også en platform, hvor detailhandelen går sammen om kampagnens budskab. Kendskabskampagnerne bliver suppleret med produktkampagner, som den enkelte kæde selv kører, og hvor der er konkurrence kæderne imellem.

Endnu en vinkel på betydningen af informationen er, at det også er nødvendigt at opbygge de ansattes vidensniveau om de miljøtilpassede/etiske produkter. De skal som minimum være i stand til at svare, hvis en kunde spørger efter en miljøtilpasset/etisk variant, eller evt. ønsker en forklaring på, hvorfor denne variant er dyrere end den konventionelle. Kæderne ønsker at give forbrugerne et valg, men ikke at træffe valget for dem. Nogle kæder prioriterer træning af de ansatte højt, ikke mindst for at 
motivere dem til at rådgive kunderne og gøre en indsats for de miljøtilpassede/etiske produkter i butikkerne.

For det andet, når man ser på selve indholdet af informationen, synes udviklingen at gå fra en indledende fase, hvor fokus er på at forklare, hvad et givet mærke står for, og til en mere nuanceret fase, hvor der bliver givet mere information om produktets miljø- eller etisk relaterede kvaliteter. Dette kan ses som et udtryk for et mere modent marked, hvor der er flere miljøtilpassede/etiske varianter af et givet produkt, og der derfor opstår konkurrence mellem disse. En detailkæde, der har sit eget, miljøtilpassede/etiske private label kan have fordel af at fremhæve netop disse produkters kvaliteter.

\subsection{Nationale forskelle og ligheder}

Som led i projektet er der set på den overordnede udbredelse af de forskellige typer miljøtilpassede/etiske produkter i de forskellige nordiske lande. Der er ganske store variationer landene imellem, og billedet er ikke entydigt, hvilket ville kræve en mere omfattende undersøgelse end der har været mulighed for i dette projekt. Med disse forbehold viser dette projekt at:

- svanen er mest udbredt i Sverige, men er også godt med i de andre lande. Vækstraterne for omsætningen er mindre end på fx økologi og fairtrade, men det absolutte niveau er højere

- økologi er mest udbredt i Danmark. Fx har den danske supermarkedskæde Irma verdens højeste markedsandel på økologiske varer, hvis man ser bort fra de $100 \%$ økologiske supermarkeder

- der er en pæn vækst i Norge, men markedet er stadig mindre end i de andre lande

- der i Finland er stor vækst på Fairtrade, men mindre på de andre mærker

- Fairtrade har de største vækstrater pt., men i absolutte tal er det stadig et lille område. Målt på omsætning per indbygger ligger Danmark på en 3. plads og Finland på en 6. plads globalt

- FSC mærkede produkter er ikke udbredt i nogen af landene, men på et beskedent grundlag synes det at være slået mest igennem i Danmark, når man ser på forbrugerprodukter. I Norge er der en udbredt skepsis over for mærket, hvilket betyder, at det stort set ikke findes i detailhandelen

- MSC mærket er det sidste skud på stammen, og derfor er såvel kendskab som produktsortiment meget lille - i Norden dog størst i Sverige, men vi ligger pænt efter lande som Tyskland og England

- Naturkosmetikmærkerne er også i vækst, men i dagligvarehandelen er det meget begrænset, hvor meget, der bliver gjort for at fremhæve disse. Her synes specialbutikkerne at være længere fremme. 
Som et fællestræk for de nordiske lande kan nævnes, at de miljøtilpassede/etiske varer primært sælges via etablerede supermarkeder - mindre via specialbutikker, som kun handler med denne type produkter. I Sydeuropa er $100 \%$ økologiske supermarkeder fx langt mere udbredt end i Norden. Fairtrade-området synes at være lidt anderledes med et salgsmønster, der er spredt over både supermarkeder, specialbutikker, nethandel samt caféer og lignende. Dette skyldes formentlig, at kaffe, te og chokolade er blandt de første og mest udbredte fairtrade produkttyper, samt at fairtrade-konceptet tiltaler unge, globalt orienterede mennesker.

Et andet fællestræk, som kan være med til at forklare, hvorfor økologi og fairtrade har oplevet stor vækst i de seneste år, er de generelt gunstige tider med højkonjunktur, hvor forbrugerne har haft luft i økonomien til at forkæle familien og købe (lidt) dyrere produkter. Endvidere kan man tale om et storbyfænomen, idet salget af miljøtilpassede/etiske varer er størst i de store byer og spreder sig herfra til de øvrige dele af landene.

Undersøgelsen giver ikke belæg for klare konklusioner på årsagerne til de nationale forskelle, men der er nogle mulige forklaringer. For det første kan det spille ind, hvilket mærke, der slog først igennem, og som der derfor har været længst og mest omfattende fokus på. Det tager lang tid at opbygge kendskab og tillid til et mærke.

For det andet kan erhvervsstrukturen og den samfundsmæssige fokus på miljø- og etiske relaterede problemstillinger i de enkelte lande spille ind. Da svanemærket blev lanceret i 1989 var der fx ganske stor debat i Sverige om papirindustrien og dens udledninger til Østersøen. Det kan have hjulpet til med at slå svanen fast og få udbredt mærket på papirprodukter. Da svanemærket blev lanceret, var Danmark det eneste land i Norden, som var med i EU, og man valgte i stedet at tilslutte sig EU's miljømærke blomsten. Først senere gik Danmark også med i svanemærket. Omvendt er økologi klart mest udbredt i Danmark, hvor landbrug er et væsentligt erhverv, og hvor der er stor opmærksomhed om landbrugets miljøpåvirkninger.

I Norge er den økologiske bølge først begyndt at rulle inden for de seneste få år, hvilket muligvis kan hænge sammen med, at der i de norske medier længe var stor skepsis over for økologi. Denne skepsis er ikke fremherskende længere, og stadig flere norske supermarkeder forhandler $ø$ øologiske varer. Fra de norske supermarkeder lyder meldingen, at økologiske produkter sælger bedst, hvis de er placeret sammen med de konventionelle produkter. Tidligere forsøg med at placere de økologiske produkter for sig selv var ingen succes. Det kunne tyde på, at det norske marked for miljøtilpassede/etiske produkter langt overvejende består af forbrugere fra det Blå segment, mens det Grønne segment ikke for alvor er slået igennem endnu.

Forbrugernes vægtning af miljø og sundhed er endnu et område, hvor der synes at være nationale forskelle. En europæisk undersøgelse af, hvorfor forbrugerne i en række EU-lande valgte at købe økologiske varer, 
viste blandt andet, at danskerne vægtede de individuelle, sundhedsrelaterede aspekter langt højere end forbrugerne i de andre lande. Dette understøttes af holdningsundersøgelser, som AIM Nielsen har udført med 5 års mellemrum blandt 25.000 personer fra de skandinaviske lande. Her blev der peget på, at miljøbevidstheden og prioriteringen af miljøbeskyttelse var stigende i Norge og Sverige, men faldende i Danmark. Dette kan dog have ændret sig i de seneste år, hvor miljøet generelt har fået større opmærksomhed igen på grund af klimadebatten.

Når man sammenligner detailhandelen i de undersøgte lande ud fra, hvad der synes at være best practice for afsætning af miljøtilpassede/etiske varer, synes der ikke at være de store nationale forskelle. Her ligger forskellene tilsyneladende mere på den enkelte kædes „personlighed“, dvs. holdninger, strategier og måder at drive forretning på.

\subsection{Forskelle mellem mærkerne}

Undersøgelsen giver ikke belæg for at sige, at supermarkederne, som forhandler flere forskellige typer miljøtilpassede/etiske produkter, bevidst satser på og prioriterer et mærke frem for andre. De forskellige mærker findes (med få undtagelser) på forskellige type produkter og er derfor ikke i direkte konkurrence med hinanden. Men undersøgelsen konstaterer, at der er forskelle i praksis.

Supermarkederne prioriterer fødevarer højst - større varehuse kan dog også have et stort non-food sortiment. Fokus på fødevarer fremmer interessen for økologi og fairtrade, og det er på fødevareområdet, at supermarkederne gerne vil give forbrugerne en mulighed for luksusoplevelser og god kvalitet. Specielt i en periode, hvor forbrugerne har økonomiske muligheder for at købe dyrere og/eller flere produkter. Prioriteringen af økologi viser sig fx i Danmark ved, at en del butikker har et „Øko-torv“ eller på anden vis skaber ekstra synlighed om de økologiske varer. Det sker ikke med de svanemærkede varer. Ligeledes har de økologiske varer deres egne varenumre, der gør det muligt at følge omsætningen, hvorimod man ikke altid ud fra varenumrene kan se, om der er tale om svanemærkede produkter eller ej.

Desuden spiller det ind, hvilke mærker supermarkedet startede med at fokusere på. Det tager flere år at opbygge et solidt kendskab til et mærke både hos forbrugerne og hos de ansatte. Så de mærker, der kom først, har generelt set størst fokus.

På svanemærket synes det at være producenterne mere end detailhandelen, som driver udviklingen i retning af flere og flere mærkede produkter - dog får detailhandelen også flere og flere svanemærkede private label varer. Inden for nogle produktkategorier som husholdningspapir og personlig pleje synes svanemærket at være blevet produktstandard, idet mærket findes på en meget stor del af sortimentet, uanset om det bliver 
fremhævet i butikken eller ej. Man kan så diskutere, om dette er i overensstemmelse med svanemærkets intention om, at kun den bedste tredjedel af produkterne i en produktkategori skal kunne leve op til kriterierne.

Der kan ligeledes være en forskel på omkostningsdannelsen og fordelingen af omkostninger mellem de forskellige typer miljøtilpassede/etiske produkter. På miljømærker som svanen vil der ofte være udviklingsomkostninger, og der skal betales en omsætningsafgift til miljømærkesekretariaterne. Til gengæld er der ikke nødvendigvis højere omkostninger relateret til råvarer og/eller produktion, sådan som der er på økologiske og fairtrade produkter. I hvor høj grad meromkostningerne bliver synlige i markedet, afhænger af den enkelte kædes politik for prissætning, og her er der variationer - fra at forbrugerne betaler den fulde merpris og til, at kæden fordeler meromkostningerne på alle produkter, så der ikke er nogen prisdifference, eller vælger at have lavere avance på nogle produkter.

\subsection{Konklusion: Hvordan fremme afsætningen af de miljøtilpassede produkter}

Fra politisk side er der i de nordiske lande ønske om at fremme afsætningen af de miljøtilpassede/etiske produkter yderligere. Som denne undersøgelse viser, så er der sket en del på markedet for miljøtilpassede/etiske produkter de seneste år - vækstraterne er pæne og stadig flere detailhandelskæder forhandler disse produkter. Markedet er med andre ord ved at modnes, detailhandelen tager det seriøst som en del af deres forretningspotentiale (dvs. ikke blot af idealisme), og inden for nogle produktgrupper har de miljøtilpassede/etiske produkter store markedsandele.

Når det er sagt, så er der stadig lang vej at gå, før de miljøtilpassede/etiske produkter bredt set bliver mainstream. Samlet set udgør de fortsat få procent af markedet, prisen er en reel barriere for mange forbrugere, og kendskabet til især de nyere mærker er ikke så udbredt. Hvis markedsandelene skal yderligere op i detailhandelen, peger denne undersøgelse på bidrag fra 4 typer af aktører: detailhandelen, producenter, organisationer og myndigheder (herunder NMRIPP).

Detailhandelen er klart den centrale part. Denne undersøgelse giver adskillige eksempler på, hvordan man kan arbejde bevidst og fokuseret på såvel det strategiske niveau som i den praktiske hverdag i butikkerne. Det er imidlertid også klart, at detailhandelen ikke alene kan løfte udfordringen med at opbygge forbrugernes kendskab og tillid til de miljøtilpassede/etiske produkter og motivere dem til at vælge disse i butikkerne.

Producenterne af varer til detailhandelen har en opgave i at fortsætte udviklingen af (nye) miljøtilpassede/etiske produkter til en god kvalitet og pris, hvilket bl.a. kan fremmes via stabile og længevarende samarbejdsaftaler med detailhandelen. Der er mange andre måder at stimulere producenternes indsats, men det er ikke en del af denne undersøgelse. 
Organisationer, der står bag de forskellige mærkningsordninger, har en central rolle i fortsat at:

- udbrede kendskabet til deres respektive mærker,

- sikre og eventuelt styrke mærkernes kvalitet og troværdighed

- udvikle kriterier for stadig flere produktgrupper

- opfordre producenter til at få mærket deres produkter, så sortimentet af de miljøtilpassede/etiske mærkede produkter stiger

Samarbejdet mellem disse og andre organisationer og detailhandelen er vigtig for fortsat udvikling, synlighed og troværdighed. Her er tilbagevendende kampagner, gerne på bestemte tidspunkter hvert år, en god platform for en fælles indsats.

\section{Myndigheder (herunder NMRIPP)}

Såfremt NMRIPP og/eller andre offentlige instanser ønsker at stimulere afsætningen af miljøtilpassede/etiske produkter, peger detailhandelen i denne undersøgelse selv på et par områder. For det første er der brug for en omfattende indsats, når det drejer sig om at opbygge forbrugernes kendskab og bevidsthed. Tilbagevendende kampagner er her en mulighed, både i en opstartsfase, hvor et nyt mærke skal introduceres og senere, hvor det handler om at skabe tyngde ved at få flere forbrugere og producenter med.

For det andet er det også vigtigt at opbygge de ansattes viden og kendskab, hvilket bl.a. kunne tænkes med ind i eksisterende uddannelsesforløb eller ved at udvikle efteruddannelsesløsninger, som er tilpasset detailhandelen og dens vilkår.

For det tredje ønsker detailhandelen at undgå (yderligere) mærkeforvirring. Der er allerede en del mærker inden for det miljøtilpassede/etiske område, og nye mærker for et særligt område kan skabe forvirring og informationsoverload hos nogle forbrugere, som risikerer at nedprioritere de mærkede varer, fordi de ikke kan overskue, hvad de forskellige mærker står for, og hvad forskellene er. Et eksempel kan ses på tekstilområdet, hvor der findes tøj, som er produceret af økologisk bomuld, andet er fairtrademærket og atter andet er mærket med svanen eller blomsten. Nogle produkter er både-og. Ifølge en interviewet tøjbutiksindehaver spørger forbrugerne efter det økologiske, ikke de andre. Det kunne indikere, at „økologi“ i nogle forbrugeres bevidsthed står som det overordnede fællesbegreb.

For det fjerde er der prisparameteren. Nogle miljøtilpassede/etiske produkter er lidt eller meget dyrere end de konventionelle, og det er en reel barriere for hovedparten af forbrugerne. Justering af fx afgiftssystemer, så det økonomisk gavner de miljøtilpassede/etiske produkter, kan overvejes. 
Endelig er der den helt overordnede signalværdi, der ligger i at politikere og andre beslutningstagere og myndigheder giver udtryk for og konkret viser, at de prioriterer indsatsen for bedre miljø og sociale forhold. Det påvirker såvel detailhandelens som forbrugernes motivation og indstilling. De positive politiske prioriteringer skal gerne være stabile over tid, så aktørerne på markedet tror på, at der ikke er tale om et forbigående modefænomen. 



\section{Bilag A: Oversigt over gennemførte interviews og butiksbesøg}

Sverige

- Miljøchef Mikael Robertsson, Coop Sverige

- CSR-ansvarlig Mimmi Brodin, Polarn o. Pyret

- Manager Environment and Social Responsibility, Kerstin Lindvall, ICA (telefon)

- Butikschef Thomas Axell, Coop Backaplan, Göteborg

- Butikschef Rebecka Berg, Polarn o. Pyret, Vallgatan, Göteborg

- Butikschef Jonas Handspik, ICA Maxi Mölndalsvägen, Göteborg

Norge

- Miljøchef Knut Lutnces, Coop Norge

- Miljøansvarlig Terje Lcrum og trade marketingchef Margrethe Edelsteen, Byggmakker

- Kategoriansvarlig Kenneth Lindland, Meny-Ultra

- Butikschef Espen Andresen, Coop Mega, Fredriksstad

- Butikschef Gunnar Eriksen, Byggmakker Saxegaard (HerføllGruppen)

- Butikschef Jon Solberg, Meny Fredrikstad

Danmark

- Miljøchef Katrine Milman, Coop Danmark

- Marketingchef Tine Guldborg Bredvig, Coop SuperBrugsen (telefon). Har siden skiftet job til non-food chef i Kvickly

- Informations- og miljøchef Henrik E. Johansen, MATAS

- PR- og kommunikationsansvarlig Thomas Uhd samt miljøkoordinator Jonas Engberg, IKEA Danmark

- Uddeler Qasiar Khan, Coop SuperBrugsen, Nørrebrogade, København

- Uddeler Micki Høyer Hansen, Coop SuperBrugsen, Ndr. Frihavnsgade, København

- Varehuschef Morten Houmann, Coop Kvickly Vordingborg

- Butikschef Carl-Erik Christensen, MATAS Allerød

- Materialist Mona Holm Sørensen, MATAS Silkeborg (telefon)

- Anonymt besøg (Mystery shopping), MATAS Bryggen i Vejle 
Desuden er der besøgt en række butikker, som ikke har været en del af den formaliserede undersøgelse, men som har bidraget til at opbygge viden om butiksindretning og prioritering af de miljøtilpassede/etiske varer. Disse omfatter bl.a.:

- City Gross, Kalmar (Sverige)

- Netto, Karlshamn (Sverige) samt Frederikssundsvej København (Danmark)

- ICA og Konsum, Torsås (Sverige)

- Rema 1000, Skovlunde (Danmark)

- Lidl, Herlev (Danmark)

- SuperBrugsen, Sædding Centret, Esbjerg (Danmark)

- SPAR, Vordingborg (Danmark)

- SuperBest, Vordingborg, samt Borups Allé, København (Danmark) 


\section{Bilag B: Anvendt spørgeguide}

Der er brugt 2 forskellige spørgeguides - en til interviews på kædernes centrale niveau og en til interviews og besøg i butikkerne.

Spørgeguiden er meget omfattende, så derfor blev spørgsmålene prioriteret. Spørgsmål markeret med kursiv havde højst prioritet.

\section{Spørgeguide til interview med central person}

Disse interviews fokuserer på kædens holdninger og strategi, herunder også hvad og hvor meget, der fastlægges centralt henholdsvis decentralt i den enkelte butik.

\section{Markedsstrategi og konkurrence}

- Har kæden er skriftlig politik/vision/strategi for afsætning af miljøtilpassede/etiske varer? Bed om kopi hvis vi ikke har den i forvejen

- Hvilken rolle kan/bør detailhandelen spille for at fremme salget af miljøtilpassede/etiske varer? Hvad er kædens grundholdning til ansvarsfordelingen?

- Hvornår og hvorfor gik de i gang med at sælge miljøtilpassede/etiske varer? Offensiv/defensiv tilgang?

- Er den miljøtilpassede/etiske indsats fokuseret på risikohåndtering af supply chain eller på markedsudvikling? (eller begge dele, men hvad er så den vigtigste drivkraft)

- Er den miljøtilpassede/etiske indsats vedvarende (opbygning af goodwill og troværdighed tager tid) eller er det mere modepræget og baseret på gode tilbud ind i mellem?

- Overvejelser om markedsstrategier, fx differentiering, tiltrække nye kundegrupper, butikken eller varerne i fokus, egne brands eller salg af mærkevarer fra andre

- Er der forskel på, hvordan kæden arbejder med de forskellige miljøtilpassede/etiske produkttyper (økologiske, fairtrade, svanemærkede osv.)? Hvilke forskelle og hvorfor?

- Er de miljøtilpassede/etiske varer primært „private label“ eller andre mærkevarer?

- Hvordan sikrer kæden seriøsitet og dokumentation for de miljømæssige/sociale aspekter (specielt hvis produkterne ikke har en 3. parts godkendelse)

- Hvilke barrierer oplever kæden for større salg af de miljøtilpassede/ etiske produkter, og hvad gør man for at overvinde disse barrierer? 
- Er de miljøtilpassede/etiske varer i konflikt med andre hensyn eller konkurrenceparametre? Hvilke?

- Hvordan vil det miljøtilpassede/etiske marked udvikle sig? Spørg om de forskellige typer varer (økologiske, fairtrade, svanemærkede, osv.)

- Er det miljøtilpassede/etiske marked et konkurrencemarked? Hvad kendetegner det miljøtilpassede/etiske marked sammenlignet med markedet for tilsvarende traditionelle varer?

- Hvem er de væsentligste konkurrenter og hvordan positionerer kæden sig i forhold til konkurrenterne generelt og specielt når det handler om de miljøtilpassede/etiske varer?

\section{Resultater: salg af miljøtilpassede/etiske produkter}

- Udvikling i omsætningen af miljøtilpassede/etiske varer, helst absolutte tal, men ellers relative tal, fx andel af samlet omsætning, stigningstakter Spørg om de forskellige typer varer (økologiske, fairtrade, svanemærkede,...)

- Erfaringer med, hvad der virker ift at få kunderne til at vælge de miljøtilpassede/etiske varer. Spørg generelt og få derefter den interviewede til at prioritere de 3 mest effektive typer af indsats $\rightarrow$ hvad mener den interviewede er best practice? Vi skal skelne mellem best practice i forhold til at skabe synlighed og i forhold til at skabe større afsætning. Det sidste er vigtigst.

- Er de miljørelaterede/etiske argumenter nok i sig selv til at sælge produkterne, eller skal der andet og mere til?

- Har kæden et eller flere særlige slogans for (nogle af) de miljøtilpassede/etiske varer? Hvem henvender disse slogans sig til? (den danske lavpriskæde Netto har fx følgende slogan: „Alle skal ha’ råd til Økologi”)

- Hvordan bliver kædens miljø/etiske politik og strategi omsat til konkret indsats i butikkerne?

- Sælges der flest miljøtilpassede/etiske varer via nettet eller i butikkerne (relativt og absolut)

- Bliver der sat forretningsrelaterede mål og indikatorer for salget af de miljøtilpassede/etiske produkter? Hvordan bliver der i givet fald fulgt op på, om målene bliver nået?

\section{Videnopbygning om „det miljøtilpassede/etiske marked“}

- Hvad gør kæden for at opbygge viden om det miljøtilpassede/etiske marked?

- Gennemføres der markedsundersøgelser om kundernes ønsker i forhold til de miljøtilpassede/etiske varer?

Er der tale om selvstændige undersøgelser, eller en delmængde af andre kundeundersøgelser? Hvad bliver svarene brugt til og hvordan? 
- Segmenterer kæden bevidst i forhold til det miljøtilpassede/etiske marked, dvs. retter sin indsats mod specifikke segmenter? Hvilke og hvordan blev de udvalgt?

- Hvem er kædens kernesegmenter, hvilke indkomstklasser er det og er der en sammenhæng mellem indkomstklasse og køb af miljøtilpassede/etiske varer?

- Hvordan samarbejder kædens markedsspecialister med de „miljøtilpassede/etiske“ specialister?

- Hvordan prioriterer kunderne de miljørelaterede/etiske aspekter i forhold til andre parametre?

- De kunder, som køber miljøtilpassede/etiske produkter, går de efter butikken og regner med at finde gode produkter, eller går de specifikt efter bestemte produkter, uanset hvilken butik, der har dem?

- Hvorfor køber kunderne de miljøtilpassede/etiske varer? (sundhed, miljøhensyn, dyrevelfærd, hensyn til udviklingslandene, smag, kvalitet,...). Hvilke forskelle er der på de forskellige typer miljøtilpassede/etiske produkter (økologiske, fairtrade, svanemærkede,...)?

- Hvilken betydning har prisen?

- Hvilken betydning har emballagen?

\section{Uddannelse og engagement af kunderne}

- Hvad betyder kundernes vidensniveau for salget af miljøtilpassede/ etiske produkter?

- Hvad gør kæden for at opbygge kundernes viden om og forståelse for de miljørelaterede/etiske spørgsmål i tilknytning til produkterne? Argumenterer man primært ud fra fakta eller oplevelser ( $\mathrm{fx}$ ved at fortælle historier om produkterne eller arrangere besøg hos producenter)

- Fokuserer kæden på at skabe forståelse for få aspekter af bæredygtighed (enkelhed) eller på mere sammenhængende forståelse og overblik?

- Hvad gør kæden for at skabe seriøsitet og undgå, at den miljørelaterede/etiske indsats får karakter af ,greenwashing“?

- Bliver kunderne aktivt involveret i at udvikle kædens indsats (fx via ønsker, prioriteringer $\mathrm{mm}$.)?

\section{Samarbejde med eksterne parter (NGO'er, medier, organisationer, myndigheder,...)}

- Samarbejder kæden aktivt med eksterne organisationer for at fremme salget af miljøtilpassede/etiske produkter? Hvem og om hvad? Hvad er formålet med og effekten af samarbejdet?

- Er der politisk, mediemæssig eller på anden måde opbakning til indsatsen? Hvilken betydning har det? 
- Har kædens indsats et filantropisk aspekt, fx donationer til bestemte formål?

\section{Samspil mellem det centrale niveau og kædens butikker}

- Hvordan er ansvarsfordelingen mellem det centrale niveau og butikkerne i relation til at sælge miljøtilpassede/etiske produkter? Hvem gør hvad? (indkøb, varesortiment, kampagner, butiksindretning,...)

- Bestemmer den enkelte butiksbestyrer fx selv, hvordan butikken skal indrettes og hvordan de forskellige varegrupper bliver synliggjort?

- Hvem er drivkræfter for at fremme salget af miljøtilpassede/etiske varer - det centrale niveau eller butikkerne? Er der konfliktende interesser?

\section{Uddannelse/træning af butikspersonale}

- Hvordan bliver butikspersonalet og andre relevante personalegrupper informeret om og uddannet til at fremme salget af miljøtilpassede/ etiske varer? På hvilket niveau - skal de fx primært kunne svare på spørgsmål fra kunderne eller skal de aktivt kunne guide kunderne frem til at foretage miljøtilpassede/etiske valg?

- Hvad gør kæden for at motivere de ansatte til at fremme salget af miljøtilpassede/etiske produkter? (fx konkurrence mellem butikker, bonusordninger, holdningspåvirkning,...)

- Fungerer de ansatte som ambassadører, dvs. fortæller de andre om butikkens miljø/etiske holdninger og produkter?

\section{Indsatsen i butikkerne}

- Hvordan bliver de miljøtilpassede/etiske produkter gjort synlige i butikkerne? (fx hyldeforkanter, prisskilte, eye-catchers, placering i butikken,...)

- Bliver der gjort en særlig indsats for at synliggøre de miljøtilpassede/ etiske produkter? Hvilken? Er der forskel på de forskellige typer miljøtilpassede/etiske produkter (økologiske, fairtrade, svanemærkede,...)

- Hvorfor er væksten stor i disse år for økologiske og fairtrade produkter, men ikke så stor for svanemærkede?

- Bliver de miljøtilpassede/etiske varer (eller nogle af dem) knyttet til et bestemt logo eller varemærke? Er der en særlig design-linje for disse varer? 
- Hvor stort er sortimentet af de miljøtilpassede/etiske varer (fordelt på de forskellige typer miljøtilpassede/etiske produkter (økologiske, fairtrade, svanemærkede,...)? Er det større/mindre end konkurrenternes?

- Er nogle varegrupper mere egnede end andre til at drive markedet? Hvilke varer er fx gode „begyndervarer“ for dem, der vil prøve de miljøtilpassede/etiske varer af, og hvilke varer appellerer mere til dem, der allerede køber nogle miljøtilpassede/etiske varer? Er der prisdifferentiering, så begyndervarerne bliver solgt med lavere avance? (eller anden form for prisdifferentiering?)

- Bliver der uddelt smags- eller vareprøver på de miljøtilpassede/etiske varer?

- Hvordan bliver emballagen brugt til at fremme synlighed og tiltrækning af de miljøtilpassede/etiske varer?

\section{Kampagner}

- Erfaringer fra gennemførte, succesfulde kampagner (dvs. kampagner, som har givet større salg): indhold, form, samarbejdspartnere, resultater,... Hvorfor var de succesfulde?

- Hvor længe varer effekten af en kampagne? Hvor ofte gennemfører kæden kampagner for at fastholde kundernes interesse?

- Bliver kampagnerne knyttet til særlige begivenheder, fx højtider som jul eller påske, eller begivenheder som eksamensfester, skolestart,...?

- Bruger kæden kendte personer som ambassadører for indsatsen?

\section{Reklamer, web-sites mm.}

- Hvilken information om CSR og miljøtilpassede/etiske produkter er der på hjemmesiden? Hvorfor netop dette og ikke andet?

- Læser kunderne denne information? (klikkes der på links, bliver der spurgt om det i butikkerne)

- Hvordan bliver de miljøtilpassede/etiske varer profileret i trykte reklamer og evt. TV-reklamer? Hvilken effekt har det på interessen og på salget?

- Hvilke andre markedsføringskanaler og -medier bruger kæden? Er noget af dette specielt for de miljøtilpassede/etiske varer?

- Hvilken rolle spiller husstandsomdelte reklamer for salget af de miljøtilpassede/etiske varer? Får de miljøtilpassede/etiske produkter mere plads eller større synlighed i reklamerne end andre varegrupper? Bliver de miljøtilpassede/etiske varer brugt som tilbudsvarer? 


\section{Mærker og anden information på produkterne}

- Hvilken betydning har mærkerne (fx Svanen, FSC, Økologi, Fairtrade) for kunderne?

- Gør mærkerne det lettere for ekspedienterne at sælge miljøtilpassede/ etiske varer? 


\section{Bilag C: Spørgeguide til interview og besøg i butikker}

Interviewet med den butiksansvarlige har til formål at kortlægge dels holdninger til og prioritering af de miljøtilpassede/etiske varer dels den konkrete indsats i butikken. Nogle af spørgsmålene er de samme som dem, vi stiller til den centrale person, men hvor vi ser det fra butikkens vinkel.

\section{Holdning og prioritering}

- Hvad tænker den butiksansvarlige på, når du siger „miljøtilpassede/ etiske varer"?

- Hvor stor en del af butikkens omsætning kommer fra miljøtilpassede/ etiske varer og hvordan har det udviklet sig?

- Er miljø og etik et modefænomen eller noget mere permanent?

- Hvordan prioriterer han/hun de miljøtilpassede/etiske varer i forhold til konventionelle varer?

- Hvem er drivkræfter for at fremme salget af miljøtilpassede/etiske varer - det centrale niveau eller butikkerne? Er der konfliktende interesser?

- Bestemmer den enkelte butiksbestyrer selv, hvordan butikken skal indrettes og hvordan de forskellige varegrupper bliver synliggjort?

\section{Indsatsen i butikkerne}

- Hvordan bliver de miljøtilpassede/etiske produkter gjort synlige i butikkerne? (fx hyldeforkanter, prisskilte, eye-catchers, placering i butikken,...) Her skal vi spørge til de forskellige varegrupper, for der kan være store forskelle mellem $\mathrm{fx}$ økologiske og svanemærkede varer

- Bliver der gjort en særlig indsats for at synliggøre de miljøtilpassede/ etiske produkter? Hvilken? Er der forskel på de forskellige typer miljøtilpassede/etiske produkter (økologiske, fairtrade, svanemærkede,...)

- Bliver de miljøtilpassede/etiske varer (eller nogle af dem) knyttet til et bestemt logo eller varemærke? Er der en særlig design-linje for disse varer?

- Hvor stort er sortimentet af de miljøtilpassede/etiske varer (fordelt på de forskellige typer produkter (økologiske, fairtrade, svanemærkede,...)? Er det større/mindre end konkurrenternes? 
- Er nogle varegrupper mere egnede end andre til at drive markedet? Hvilke varer er fx gode „begyndervarer“ for dem, der vil prøve de miljøtilpassede/etiske varer af, og hvilke varer appellerer mere til dem, der allerede køber nogle miljøtilpassede/etiske varer? Er der prisdifferentiering, så begyndervarerne bliver solgt med lavere avance? (eller anden form for prisdifferentiering?)

- Bliver der uddelt smags- eller vareprøver på de miljøtilpassede/etiske varer?

- Hvordan bliver emballagen brugt til at fremme synlighed og tiltrækning af de miljøtilpassede/etiske varer?

- Hvad gør butikken for at adskille sig fra de lokale konkurrenter?

- Hvordan er kundernes interesse for de miljøtilpassede/etiske produkter? Hvordan kommer det til udtryk og hvordan har det udviklet sig over tid?

Vigtigt: Hvad anser den butiksansvarlige selv for at være „best practice“ i forhold til at sælge miljøtilpassede/etiske varer? Kommer det til udtryk i hans/hendes butik, eller kan han/hun pege på en butik, hvor det findes? Er butikkens omsætning af de miljøtilpassede/etiske varer større eller mindre end de andre butikker i kæden? Er omsætningen større/mindre end de lokale konkurrenters? Vælger (nogle af) kunderne denne butik på grund af en etisk profil?

\section{Kampagner}

- Hvilken effekt mærker butikken af en kampagne (fx økologi, fairtrade,...) og hvor længe varer effekten? Hvor ofte gennemfører kæden kampagner for at fastholde kundernes interesse?

- Bliver kampagnerne knyttet til særlige begivenheder, fx højtider som jul eller påske, eller begivenheder som eksamensfester, skolestart,...?

\section{Mærker og anden information på produkterne}

- Hvilken betydning har mærkerne (fx Svanen, FSC, Økologi, Fairtrade) for kunderne?

- Gør mærkerne det lettere for ekspedienterne at sælge miljøtilpassede/ etiske varer?

\section{Uddannelse/træning af butikspersonale}

- Hvordan bliver butikspersonalet informeret om og uddannet til at fremme salget af miljøtilpassede/etiske varer? På hvilket niveau - skal 
de fx primært kunne svare på spørgsmål fra kunderne eller skal de aktivt kunne guide kunderne frem til at foretage miljøtilpassede/ etiske valg?

- Hvad gør butikken for at motivere de ansatte til at fremme salget af miljøtilpassede/etiske produkter? ( $\mathrm{fx}$ bonusordninger, holdningspåvirkning,...)

- Fungerer de ansatte som ambassadører, dvs. fortæller de andre om butikkens miljø/etiske holdninger og produkter?

\section{Rundtur i butikken}

Noter og fotografer, hvordan de miljøtilpassede/etiske varer er placeret og synliggjort i butikken med skilte osv. 



\title{
Bilag D: Referenceliste
}

\author{
Anvendte kilder til gennemgangen af mærkningsord- \\ ninger og afsætning af miljøtilpassede/etiske produkter
}

\section{Miljømcerkning:}

ACNielsen, 2005: Miljømerkede produkter 2000-2004.Undersøgelse for Stiftelsen Miljømerking

Informationscenteret for Miljø \& Sundhed: brochuren „Ren informa-tion om mærker og miljø"

TemaNord 2008:529: The Nordic Swan From past experiences to future possibilities. Nordisk Ministerråd, 2008.

\section{Økologi:}

CONDOR-projektet: www.condororganic.org

Danmarks Statistik www.statistikbanken.dk

Danmarks Statistik: NYT fra Danmarks Statistik, nr. 183, 2. maj 2007

Ekologiska Lantbrukarna 2006: Växande marknad - Försäljning, volymer og trender för ekologisk mat

Ekologiskt Lantbruk, nr. 8, 2007, downloadet fra www.ekolantbruk.se/tidningen/ marknadssidor

EU's officielle hjemmeside om økologi: www.ec.europa.eu/agriculture/organic/ home_da

Konsumentverket/KO: PM 2004:19: „Pris och utbud av ekologisk mat samt miljøinformation i butik. Resultat från en undersökning av 67 ekologiska livsmedel på 11 orter under hösten 2004”

\section{Naturkosmetik:}

Miljøstyrelsens kosmetikguide, downloadet fra www.mst.dk/kemikalier/ forbrugerguide/kosmetikguiden

Urtegården: Regulering og certificering af naturkosmetik. Downloadet fra www.urtegaarden.dk
Internationalt: www.ecolabel.com, produktdatabasen Miljømærkning Danmark:

www.ecolabel.dk

Miljømærkning Finland: www.ecolabel.fi Miljømærkning Norge: www.ecolabel.no, Miljømærkning Sverige: www.ecolabel.se Svenska Naturskyddsföreningen, www.snf.se

Konsumentverket, Rapport 2006:13 „Ecologiska Livsmedel - ett strategiunderlag för livsmedelsbranchen”

KRAV- brochure (2006): „Nu bliver KRAV-märkets värde ännu tydligare Leder i Bornholms Tidende 20. december 2006, her citeret fra www.oekobornholm.dk

Præsentation af Eivind Jacobsen, SIFO, Norge, på konferencen „Samling Økologisk Landbruk for projektledere og fmla" Ren Mat, Norge, september 2007

Wright, S. and McCrea, D. (ed.) 2007: „The Handbook of Organic and Fair Trade Food Marketing”, Oxford, Blackwell Publishing

Økobarometer 2005. Downloadet fra www.ecocommerce.no/pdfs/ økobarometer-2005.pdf
BDIH-mærket: www.kontrolliertenaturkosmetik.de

Soil Association: www.soilassociation.org/ Ecocert : www.ecocert.com

Cosmebio : www.cosmebio.org

Foreningen for Naturkosmetik i Finland: www.kauneussivut.fi 


\section{Fairtrade:}

Fairtrade Labelling Organisations International: www.fairtrade.net

Fairtrade Labelling Organisations International: Annual Report 2007

Max Havelaar Danmark:

www.maxhavelaar.dk

\section{Energimcerkning:}

Energistyrelsen i Danmark: www.ens.dk

FSC:

FSC Danmark: www.fsc.dk FSC International: www.fsc.org

FSC Sverige, www.fsc-sverige.org

MSC:

Gemba Seafood Consulting 2007: Kodeks for et bæredygtigt og ansvarligt dansk fiskeri - Baggrundsrapport nr. 5: Eco-labelling

IFM og Gemba Innovation, 2007: Resumé af "Kodeks for et bæredygtigt og ansvarligt dansk fiskeri"

\section{ØkoTex:}

OekoTex Association: www.oeko-tex.com

TCO:

Miljøstyrelsen, Miljøprojekt nr. 737: Synliggørelse af de vigtigste forbrugerrelaterede miljøegenskaber ved elektronikprodukter

\section{Virksomheder:}

Coop Danmark: www.coop.dk

Coop Norge: www.coop.no

Coop Sverige: www.coop.se

\author{
Max Havelaar Norge: \\ www.maxhavelaar.no \\ Rättvisemärkt Sverige: \\ www.rattvisemarkt.se \\ Rejäl handel/Reilukauppa Finland: \\ www.reilukauppa.fi
}

Interview med Søren Eliasen, IFM (International Fisheries Management),

Aalborg Universitet

MSC Sverige: www.sv.msc.org

WWF: www.hvaforenfisk.dk
TCO Development, www.tcodevelopment.se

COOP Nordens Årsberetning 2006, downloadet på www.coop.se ICA, årsberetning 2007, downloadet på www.ica.se 


\section{Øvrigt:}

Konsumentverket/KO: PM 2004:19: Pris och utbud av ekologisk mat samt miljöinformation i butik

Martha Förbundet, Finland (2005): I valet och kvalet, downloadet fra www.martha.fi

Miljøstyrelsen, Environmental Project no. 904, 2004: Consumption and the Environment in Europe

Retail Institute Scandinavia: Nyhedsbrev 4. kvartal 2007

SIFO, Projektnotat n.1 2006: Etisk politisk forbrug

\section{Kilder til ikke-nordiske cases:}

Acona, 2005: The Customer Assumption, downloadet på www.acona.uk

Simon Wright and Diana McCrea (eds.): The Handbook of Organic and Fair Trade Food Marketing. Oxford: Blackwell Publishing 2007

\section{Hjemmesider for detailhandelen:}

www.coop.no
www.byggmakker.no
www.meny.no
www.norgesgruppen.no
www.rema1000.no
www.kiwi.no
www.coop.se
www.ica.se
www.citygross.se
www.bergendahlsgruppen.se
www.axfood.se
www.polarnopyret.se
www.hennes-mauritz.com
www.lindex.se
www.ikea.com

SIFO, Fagrapport nr.2-2005: Å sette pris på hylleplassen

TemaNord 2003:532: Etisk mærkning af fødevarer, kort udgave. Nordisk Ministerråd, 2003

TemaNord 2007:527: Jämförelse av olika informationsmetoder om etiska förhållanden i livsmedelproduktionen. Nordisk Ministerråd, 2007

Trendwatching.com, Newsletter May/June 2008: Eco-Iconic

Miljøprojekt nr. 713, Miljøstyrelsen, Danmark, 2002: Internationale erfaringer med udvikling og salg af grøn forbrugerelektronik

Hjemmesider for udvalgte, ikke tidligere ncevnte, NGO'er, organisationer og myndigheder:

www.naturvardsverket.se

www.sft.no

www.mst.dk

www.konsumentverket.se

www.forbrug.dk

www.kuluttajavirasto.fi

www.finfood.fi

\author{
www.coop.dk \\ www.matas.dk \\ www.kvickly.dk \\ www.superbrugsen.dk \\ www.superbest.dk \\ www.dansksupermarked.dk \\ www.netto.dk \\ www.lidl.dk \\ www.kesko.fi \\ www.retail-institute-scandinavia.dk \\ www.svenskhandel.se \\ www.danskerhverv.dk \\ www.holdnorgerent.no \\ www.dmf.no \\ www.dlf.no
}




\section{Øvrigt:}

Kvicklys økologiske kogebog, 2007: ØKO

Artikel: Vi køber flere økologiske fødeva-

Remixed. Udarbejdet i samarbejde med

rer, på www.epn.dk, 14. september 2008

Økologisk Landsforening og kokken

Tina Scheftelowitz. 


\section{Bilag E: Oversigt over projektets referencegruppe}

Nordisk Ministerråds gruppe for IPP

- Claus Egeris Nielsen, Forbrugerstyrelsen, Danmark, cen@fs.dk

- Inger-Grethe England, SFT, Norge, inger-grethe.england@sft.no

- Ari Luukinen, Konsumentverket, Finland, ari.luukinen@kuluttajavirasto.fi

Myndigheder

- Anita Lundström, Naturvårdsverket, Sverige, anita.lundstrom@naturvardsverket.se

Ekspert/analytiker indenfor detailhandelsafscetning

- Flemming Birch, Chefredaktør, Retail Institute Scandinavia (konsulentfirma),fb@retail-institute-scandinavia.dk

\section{Nordisk miljømærkning}

- Jan Erik Stokke, Informationschef, Miljømærkning Norge, jan.erik.stokke@ecolabel.no

- Karin Carlsson, SIS, Miljömerking Sverige, karin.carlsson@svanen.nu

\section{Brancheorganisationer}

- Jens Olav Flekke, Dagligvarehandelens Miljø- og Emballasjeforum, Norge, jof@dmf.no

- Mette Feifer, CSR-konsulent, Dansk Erhverv, mfe@danskerhverv.dk

Fair Trade organisationer

- Pia B. Lindhardt, Max Havelaar Danmark, pia@maxhavelaar.dk, tlf. 21622666

- Loa Dalgaard Worm, FSC Danmark, loa@fsc.dk, tlf. 28780819

- Bjørn Tore Heyerdahl, Fairtrade Max Havelaar, Norge, bth@fairtradenorge.no

- Tuulia Syvänen, Reilukauppa, Finland, tuulia.syvanen@reilukauppa.fi 
Forskere med viden på området

- Kristiina Aalto, seniorforsker, Konsumentforskningscentralen, Finland, kristiina.aalto@ncrc.fi

\section{Interesseorganisationer}

- Thomas Breck, Informationscentret for Miljø og Sundhed, Danmark tb@miljoeogsundhed.dk

- Håkon Lindahl, Grønn Hverdag, Norge, haakon@gronnhverdag.no 